UNIVERSIDADE DE SÃO PAULO

FACULDADE DE FILOSOFIA, LETRAS E CIÊNCIAS HUMANAS

DEPARTAMENTO DE GEOGRAFIA

\title{
ESTUDO MACRO E MICROMORFOLÓGICO DE UMA TOPOSSEQUÊNCIA NA BACIA DO CÓRREGO DO RETIRO EM SÃO PEDRO-SP
}

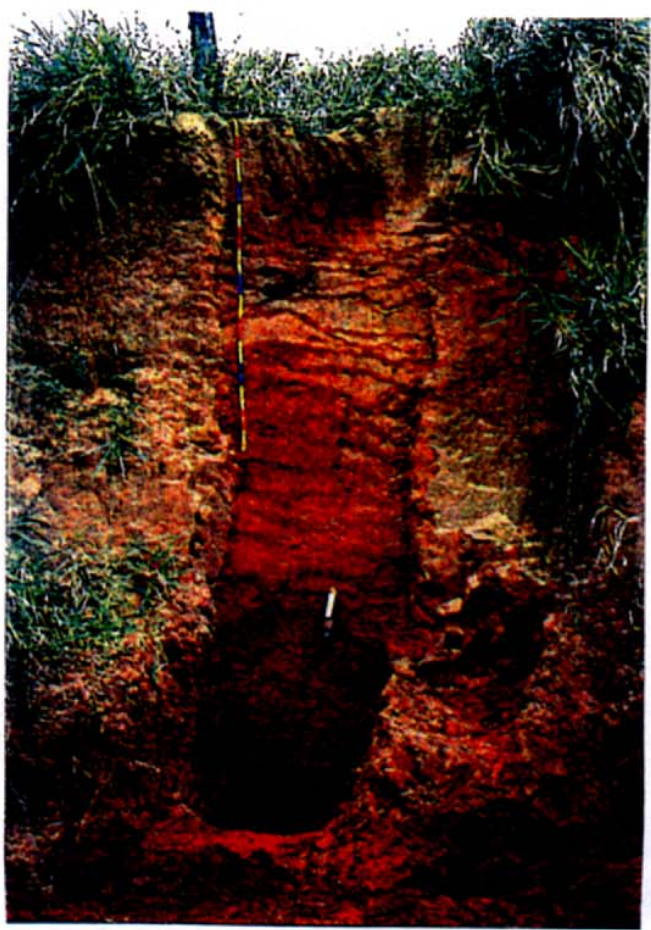

$$
\text { DÉBORAH DE OLIVEIRA }
$$

ORIENTADORA: PROFa. Dra. SELMA SIMÕES DE CASTRO

Dissertação apresentada ao Departamento de Geografia da FFLCH-USP para obtenção do grau de Mestre em Geografia Física

São Paulo - 1997 
UNIVERSIDADE DE SÃO PAULO

FACULDADE DE FILOSOFIA, LETRAS E CIÊNCIAS HUMANAS

DEPARTAMENTO DE GEOGRAFIA

\title{
ESTUDO MACRO E MICROMORFOLÓGICO DE
}

\section{UMA TOPOSSEQUÊNCIA NA BACIA DO \\ CÓRREGO DO RETIRO EM SÃO PEDRO-SP}

\author{
DÉBORAH DE OLIVEIRA \\ ORIENTADORA: PROFa. Dra. SELMA SIMŌES DE CASTRO
}

Dissertação apresentada ao Departamento de Geografia da FFLCH-USP para obtenção do grau de Mestre em Geografia Física

São Paulo

1997 
Ao Denis, aos meus pais e à Deise 


\section{AGRADECIMENTOS}

Ao Departamento de Geografia e Laboratório de Pedologia pelo apoio e suporte técnico no uso de suas dependências.

À FAPESP (Fundação de Amparo à Pesquisa do Estado de São Paulo) pelo apoio financeiro, sem o qual não seria possível a realização desta pesquisa.

À todos os componentes do Grupo Nostradamos que contribuíram na realização do primeiro grande trabalho de levantamento dos solos da vertente estudada.

Ao Centro da ORSTOM em Cayena, Guiana Francesa, na pessoa do Dr. René Boulet, pela realização da análise granulométrica.

Ao Departamento de Ciência do Solo da ESALQ-USP, pela realização das análises químicas, financiadas pela FAPESP.

Ao Departamento de Planejamento Regional-UNESP de Rio Claro, na pessoa da Profa. Dra. Nádia Regina do Nascimento e da técnica Sueli Teodoro pelo apoio na fabricação de lâminas delgadas.

Ao José Edézio da Cunha, pela amizade, atenção e paciência com que auxiliou no período de fabricação das lâminas delgadas em Rio Claro.

À Profa. Dra. Maria Cristina Motta de Toledo e das técnicas Verônica Gabriel dos Santos e Angélica Dolores de Mello Morente do Instituto de Geociências-USP, que gentilmente cederam o uso das dependências para a descrição micromorfológica e tomada de fotomicrografias.

À Vânia Silvia Rosolen e Arnaldo Alcover Neto, amigos que sempre estiveram dispostos ao diálogo e ao auxilio nos problemas técnicos da pesquisa.

À Maria Luisa Nacca, ex-estagiária do Laboratório de Pedologia-USP, pela participação na tabulação dos resultados iniciais deste trabalho. 
Ao Prof. Jean Brillant da Aliança Francesa, auxiliador na tradução do resumo do trabalho.

À Floripes Piné Garcia, técnica do Laboratório de Pedologia-USP, pelo carinho, amizade e por estar sempre pronta a ajudar.

Ao Marcelo Aparecido de Oliveira e Benjamin Capellari, amigos e companheiros de campo e laboratório.

À minha irmã Deise de Oliveira, companheirinha dos finais de semana, enquanto o trabalho ia se desenvolvendo.

Ao Denis Guimarães de Souza, companheiro carinhoso, mas crítico quando necessário, muito obrigada pela sua paciência e incentivo constante. Como é bom estarmos crescendo juntos!

Ao Dr. René Boulet, pela importante orientação nos trabalhos de campo, na impregnação de amostras indeformadas, na fabricação de lâminas delgadas e também pela tomada de fotomicrografias e revisão do texto.

À Profa. Dra. Rosely Pacheco Dias Ferreira pelo seu carinho, amizade, companheirismo e cumplicidade durante estes anos de minha participação no Projeto São Pedro.

À Profa. Dra. Selma Simões de Castro, pela dedicação e competência com que orientou esta pesquisa e à amizade que se consolidou ao longo desses anos de trabalho juntas.

\section{MUITO OBRIGADA A TODOS!}




\section{RESUMO}

A presença de bandas onduladas superpostas e anastomosadas em perfis de solos situados na borda do glacis de São Pedro, na bacia do Córrego do Retiro, na sua transição para uma zona mais dissecada à jusante, sugeriram tratar-se de solos intermediários entre as Areias Quartzosas e os Podzólicos VermelhoAmarelos.

O estudo macro e micromorfológico acompanhado de análises convencionais de laboratório (granulometria, análises químicas) seguiu o procedimento proposto por BOULET et al (1982, a, b) denominado Análise Estrutural da Cobertura Pedológica e priorizou uma topossequência representativa, na qual o sistema pedológico estudado é constituido por Areias Quartzosas com bandas onduladas no topo, Podzólico Vermelho-Amarelo na vertente e Litossolo na base.

O trabalho de campo revelou a presença de uma passagem lateral do horizonte com bandas onduladas ao horizonte $\mathrm{Bt}$ através da coalescência e espessamento dessas bandas, que ocorrem tanto no topo, como na base e dentro do Bt, até desaparecerem para jusante, onde este se torna mais estruturado e se degrada por hidromorfia.

A análise micromorfológica revelou a presença de um importante plasma iluvial na forma de cutãs ligando grãos e no interior de poros, orientados, muito bem desenvolvidos e ferruginizados no interior de estrutura de base porfírica, tanto nas bandas onduladas como no Bt. No trecho onde este se degrada por hidromorfia os cutãs se desmantelam originando pequenos fragmentos (pápulas) na porosidade e também no interior do fundo matricial próximo aos restos de cutãs, alguns fortemente integrados.

A análise granulométrica demonstrou $\circ$ predomínio de areia fina nos solos estudados e confirmou uma quantidade maior de argila nas bandas onduladas e no Bt, corroborando a interpretação de iluviação. 
A análise química confirmou que a mobilidade maior é a física dos constituintes, dada a similaridade da distribuição dos teores encontrados em relação aos horizontes da topossequência e também confirmou a pobreza dos solos.

O sistema pedológico estudado trata-se de um sistema de transformação pedológica lateral ainda em atividade, onde as bandas onduladas são responsáveis pela transformação das Areias Quartzosas em Podzólico Vermelho-Amarelo através da formação de horizonte Bt. Esses solos com bandas onduladas significam o estágio intermediário da pedogênese ligada à instabilização e translocação das argilas das Areias Quartzosas, relacionada à dinâmica da circulação hídrica vertical e lateral condicionada à evolução morfogenética das bordas do glacis de São Pedro por convexização aparentemente correlativa da dissecação quaternária. 


\section{RÉSUMÉ}

La présence de bandes ondulées superposées et anastomosées dans le profils de sols situés au bord du glacis de São Pedro, bassin du Córrego do Retiro dans sa transition vers une zone plus disséquée en aval, ont suggéré qu'il s'agissait de sols intermédiaires entre les Sables Quartzeux et les Podzoliques Rouge-Jaunes.

L'étude macro et micromorphologique accompagnée des analyses conventionnelles de laboratoire (granulométrie, analyses chimiques) a suivi le procédé proposé par Boulet et al (1982 a,b) appelé Analyse Structurale de la Couverture Pédologique et a donné la priorité à une toposéquence représentative où le systéme pédologique étudié est constitué de Sables Quartzeux avec bandes ondulées au sommet, Podzolique Rouge-Jaune sur la versant et Lithosol à la base.

Le travail de terrain a indiqué la présénce d'un passage latéral d'horizon avec bandes ondulées dans l'horizon Bt, par la coalescence et l'épaississement de ces bandes, qui apparaissent au-dessus, au-dessous et à l'intérieur du Bt, jusqu'a sa disparition. Cet horizon devient alors plus structuré en aval et se dégrade immédiatement après par l'hydromorphie.

L'analyse micromorphologique a révélé la présénce d'un important plasma illuvial sous la forme de cutanes liant des grains et à l'intérieur des pores orientés, bien développés et ferruginisés à l'intérieur de la structure porphyrique, aussi bien dans les bandes ondulées que dans le Bt. Dans le tronçon où le Bt le se dégrade par hydromorphie, les cutanes se démantèlent, originant de petits fragments (papules) dans la porosité et aussi à l'intérieur du fond matriciel proche des restes de cutanes fortement intégrés.

L'analyse granulométrique a démontré la prédominance de sable fin dans les sols étudiés et a confirmé l'existénce d'une plus grande quantité d'argile dans les bandes ondulées et le Bt, ce qui corrobore l'interprétation d'illuviation.

L'analyse chimique a confirmé que la plus grande mobilité est la physique des constituants, étant donné la similarité de la distribuition des titrages trouvés 
dans les horizons de la toposéquence et a aussi confirmé la pauvetré de ces sols.

Dans le systéme pédologique étudié, il s'agit d'un systéme de transformation pédologique latéral encore en activité, où les bandes ondulées sont responsables de la transformation des Sables Quartzeux en Podzolique RougeJaune par la formation d'un horizon Bt. Ces sols avec bandes ondulées représent un stage intermédiaire de la pédogènese lié à l'instabilisation et à la translocation des argiles des Sables Quartzeux en rapport avec la dynamique de la circulation hydrique verticale et latérale soumisé à l'évolution morphogénétique des bords du glacis de São Pedro par la convexisation apparemment corrélative de la dissécation quaternaire. 


\section{ÍNDICE}

AGRADECIMENTOS III

RESUMO $V$

RÉSUMÉ VII

1 INTRODUÇÃO

1.1 Problemática principal de estudo 1

1.2 Objetivos do trabalho 14

1.3 Área de pesquisa 14

1.3.1 Localização 14

1.3.2 Geologia 16

1.3.3 Geomorfologia 17

1.3.4 Solos 23

1.3.5 Clima, vegetação e uso do solo 25

1.4 Bases conceituais e metodológicas adotadas: revisão 26 bibliográfica

1.4.1 A cobertura pedológica: conceitos, bases para seu 26 estudo e tipos de evolução

1.4.2 Algumas interpretações sobre a origem das Areias 31 Quartzosas, das bandas onduladas e dos horizontes $\mathrm{Bt}$

2 PROCEDIMENTOS DE ESTUDO 40

2.1 Critérios de seleção da área específica 40

2.2 Levantamento de campo: macromorfologia 40

2.3 Micromorfologia 45

2.4 Análises rotineiras e convencionais de laboratório 46

3 RESULTADOS OBTIDOS 50

3.1 Macro e micromorfologia da Topossequência Retiro I 50

3.1.1 Síntese da macro e micromorfologia 78

da TopossequênciaRetiro I

3.2 Estudo analítico 84

3.2.1 Granulometria $\quad 84$

3.2.2 Análises químicas $\quad 91$

4 INTERPRETAÇÕES E CONSIDERAÇÕES FINAIS 98

5 REFERÊNCIAS BIBLIOGRÁFICAS 101 


\section{ÍNDICE DAS ILUSTRAÇÕES}

FIGURAS:

FIGURA 1 - Localização da área de estudo 15

FIGURA 2 - Hipsometria da área de estudo e seu entorno 19

FIGURA 3 - Esboço morfológico da área de estudo e seu entorno 21

FIGURA 4 - Esboço pedológico da área de estudo e seu entorno 24

FIGURA 5 - Mapa de curvas de isodiferenciação e localização das 43

trincheiras

FIGURA 6 - Fluxograma das etapas da pesquisa 49

FIGURA 7 - Topossequência Retiro I 52

FIGURA 8 - Perfis de Areia Quartzosa com bandas onduladas 55

intermediária para Podzólico Vermelho Amarelo do segmento

superior da Topossequência Retiro I

FIGURA 9 - Perfis da passagem lateral das bandas onduladas

ao Bt da Areia Quartzosa com bandas onduladas para Podzólico

Vermelho Amarelo do segmento superior da Topossequência Retiro I

FIGURA 10 - Perfis do Podzólico Vermelho Amarelo do segmento 64

médio da Topossequência Retiro I

FIGURA 11 - Perfis do Litossolo do segmento inferior da

Topossequência Retiro I

FIGURA 12 - Gráficos da distribuição percentual de plasma,

esqueleto e poros e das estruturas de base dos perfis

representativos da Topossequência Retiro I

FIGURA 13 - Síntese das estruturas micromorfológicas dos

principais horizontes da Topossequência Retiro I

FIGURA 14 - Curvas de isovalores da argila

FIGURA 15 - Curvas de isovalores da relação textural areia fina/

areia grossa

FIGURA 16 - Distribuição da Soma de Bases Trocáveis (S) 
FIGURA 17 - Distribuição da Capacidade de Troca de Cátions (T)

FIGURA 18 - Distribuição da Saturação em Bases (V\%)

FIGURA 19 - Distribuição do índice Ki

\section{QUADROS:}

QUADRO 1- Síntese das características das Areias Quartzosas segundo vários autores

QUADRO 2 - Síntese das características das Areias Quartzosas

intermediárias para podzólico Vemelho segundo vários autores

QUADRO 3 - Síntese das características dos Podzólicos

Vermelho-Amarelos segundo vários autores

\section{FOTOS:}

FOTO 1 - Perfil de Areia Quartzosa com bandas onduladas

FOTO 2 - Visão geral da vertente

\section{PRANCHAS:}

PRANCHA 1-Micromorfologia do segmento superior da

\section{Topossequência Retiro I}

FOTOMICROGRAFIA 1 - L.N. 30X. Aspecto geral do horizonte E da TR 3 com plasma formando um reticulado com grãos limpos em seu interior.

FOTOMICROGRAFIA 2 - L.N. 30X. Aspecto geral do material interbandas do horizonte $\mathrm{E}$ com bandas onduladas do perfil SPFR 8, onde predomina um reticulado com esqueleto ligado por pontes de plasma (estrutura gefúrica) em seu interior.

FOTOMICROGRAFIAS 3a e 3b - L.N. e L.P. 80X. Cutãs de iluviação do topo de banda ondulada do horizonte Eb do perfil SPFR 8.

FOTOMICROGRAFIAS 4a e 4b - L.N. e L.P. 80X. Cutãs de iluviação da base da banda ondulada do horizonte Eb do perfil SPFR 8. 
FOTOMICROGRAFIA 5 - L.P. 125X. Cutãs de iluviação do interior da banda ondulada do horizonte Eb do perfil SPFR 8.

FOTOMICROGRAFIA 6 - L.N. 80X. Detalhe de um cutã de iluviação fissurado do limite inferior da banda do horizonte Eb do perfil SPFR 8.

FOTOMICROGRAFIA 7 - L.P. 80X. Aspecto geral do horizonte C1a do perfil SPFR 14.

PRANCHA 2- Micromorfologia do segmento médio da 70 Topossequência Retiro I

FOTOMICROGRAFIA 8a e 8b- L.P. 60X. Cutãs de iluviação horizonte Bt da TR 5.

FOTOMICROGRAFIAS 9a e 8b - L.N. e L.P. 80X. Cutã de iluviação desmantelado do Bt hidromórfico (Btg) da TR 1.

FOTOMICROGRAFIAS 10a e 10b - L.N. e L.P. 60X. Cutã de iluviação fissurado do Btg da TR 1.

FOTOMICROGRAFIA 11 - Aspecto geral das litorrelíquias encontradas na alterita do arenito Pirambóia da TR 1.

PRANCHA 3- Micromorfologia do segmento inferior da 76

Topossequência Retiro I

FOTOMICROGRAFIAS 12a e 12b - L.N. e L.P. 80X. Plasma amarelo do horizonte E da TR 4, com minerais primários (muscovita, plagioclásio) pouco alterados.

FOTOMICROGRAFIA 13 - L.N. 30X. Aspecto geral da alterita com justaposição de zona bruno-acinzentada-clara e zona com cores variegadas da TR 4.

FOTOMICROGRAFIAS 14a e 14b - L.N. e L.P. 80X. aspecto geral da alterita do arenito da TR 4, com minerais primários preservados (muscovita, plagioclásio). FOTOMICROGRAFIA 15 - L.P. 30X. Estratos alternados de areia fina e média com plasma amarelo e negro da alterita do arenito da TR 7 . 


\section{TABELAS:}

TABELA 4 - Relações texturais B/A e de outros horizontes em relação aos horizontes $A$ e $E$.

\section{ANEXOS:}

ANEXO I

QUADRO 4 - Resultados da análise granulométrica

QUADRO 5 - Resultados das análises químicas

\section{ANEXO II}

Descrição morfológica das trincheiras da Topossequência Retiro I

ANEXO III

TABELA 1 - Distribuição percentual de plasma, esqueleto e poros

por horizonte na Topossequência Retiro I

TABELA 2 - Distribuição das estruturas de base por horizonte na Topossequência Retiro I

TABELA 3 - Distribuição das estruturas plásmicas por horizonte na Topossequência Retiro I

\section{ANEXO IV}

PRANCHA 4 - Variação textural em profundidade por perfil

com valores percentuais acumulados

PRANCHA 5 - Variação em profundidade por perfil dos resultados das análises químicas 


\section{INTRODUÇÃO}

\subsection{Problemática principal de estudo}

Durante a década de 70, no município de São Pedro-SP, foram desenvolvidos trabalhos de pesquisa por uma equipe franco-brasileira, que tiveram como objetivo a cartografia geomorfológica e das formações superficiais na escala 1:50.000 (QUEIROZ NETO \& JOURNAUX, 1978), da região compreendida entre o reverso imediato da Serra de São Pedro ao norte e o rio Piracicaba ao sul, o Ribeirão Vermelho a oeste e o Ribeirão Araquá a leste, aproximadamente. Tais trabalhos privilegiaram observações morfológicas de perfis de solos e de formações superficiais, cujas amostras sofreram análises físicas, químicas e mineralógicas convencionais e resultaram na Carta Geomorfológica de São Pedro.

No memorial que acompanha a carta então elaborada, ressaltou-se a presença de uma superfície com 9 a $10 \mathrm{~km}$ de extensão e cerca de $5 \mathrm{Km}$ de largura, orientada na direção N-S e que se inicia junto ao sopé da referida Serra de São Pedro, denominação local da Cuesta Arenítico-Basáltica e termina próximo à várzea do Rio Piracicaba. Os autores denominaram tal superfície de glacis de São Pedro.

Nos seus primeiros 6 a $7 \mathrm{Km}$ ao norte, tal superfície apresenta-se na forma de amplos interflúvios muito suaves e pouco dissecados que se estreitam para o sul, onde nos 2 a $3 \mathrm{Km}$ finais desfaz-se em interflúvios cada vez menores, mais estreitos, alongados e sinuosos, que segundo os autores são produto de intenso entalhamento pela rede de drenagem.

No setor mais preservado ao norte, os autores registraram a ocorrência de espessas coberturas arenosas, homogêneas morfológica e texturalmente, embora apresentem ligeiro aumento de argila em profundidade, que entretanto não chega a atingir 20\%, mas é sempre maior que o teor de argila do substrato, ao redor de 5\% (SOARES 1973), os arenitos da Formação Pirambóia e que 
correspondem às Areias Quartzosas (AQ), tal como o mapeado por OLIVEIRA \& PRADO (1989), que se estendem praticamente do topo à base das longas vertentes.

No setor mais dissecado ao sul essas Areias Quartzosas cedem lugar aos solos Podzólicos que passam a predominar tanto nos topos como nas vertentes dos interflúvios, nas quais por vezes são interrompidas por degraus estruturais onde ocorrem Litossolos.

BARRETO (1970) também estudou a região de São Pedro, mas do ponto de vista geomorfológico, dividindo a região em Depressão Periférica (que corresponderia ao glacis de São Pedro), a zona de articulação entre a Depressão Periférica e o Planalto Ocidental (a cuesta ou Serra de São Pedro) e o reverso da cuesta. A autora pouco se refere aos solos, e, na Depressão Periférica, como ela assim denomina, apenas menciona a existência de solos arenosos, muito sujeitos à erosão.

DEMATTÊ \& HOLOWAYCHUK $(1977, a)$ afirmaram que a região de São Pedro constitui um extenso pedimento, cujo setor sul corresponde a uma superfície erosional mais recente, onde a denudação é um processo ativo, constituindo uma nova superfície mais rebaixada que está se expandindo e destruindo o setor norte, ainda hoje mais preservado.

A região de São Pedro, como todo o Brasil de sudeste, sofreu uma evolução morfogenética relacionada à alternância de períodos de clima tropical seco e úmido. Durante a vigência de climas mais secos, com predominância de ações mecânicas, foram esculpidas superfícies de erosão (glacis, pediplanos) e depositados materiais mais grosseiros (blocos de desmoronamento e lençóis fluviais) ou amplas coberturas arenosas (QUEIROZ NETO \& JOURNAUX, 1978) A elaboração do glacis, segundo esses autores, relaciona-se à extensa fase tropical seca que se estendeu do final do Plioceno até o Quaternário Inferior (Pleistoceno). O conjunto do glacis foi reesculpido pelo entalhe fluvial Quaternário, achando-se melhor preservado no setor norte mais próximo à escarpa, sobretudo no interflúvio entre os vales dos Ribeirões do Meio e 
Samambaia, razão pela qual foi escolhido este interflúvio para o presente estudo.

Convém lembrar que pedimentos de erosão são vastos planos, suavemente inclinados, cujo declive varia em função dos processos atuantes e da litologia e estão em contato com uma vertente íngreme (que no caso da região de São Pedro corresponde a uma escarpa de cuesta), podendo ou não existir uma cobertura detrítica colúvio-aluvial em trânsito, sendo a superfície rochosa uma superfície de transporte. (PENTEADO, 1974)

DRESCH (1962) afirma que os pedimentos são superfícies de erosão em rochas duras e os pedimentos descritos em rochas sedimentares foram denominados de glacis de erosão pelos autores franceses. Segundo este autor, a elaboração dos glacis corresponde a períodos climáticos com alternância de períodos secos e mais úmidos, no qual no decorrer do último, a potência aumenta mais do que a carga de detritos. Segundo este autor, no contato do glacis com a escarpa há um declive íngreme e côncavo, pois os detritos são de textura mais grosseira. Para jusante, como os detritos são mais finos, o glacis passa para uma inclinação retilínea.

Para TRICART et al (1972) a origem de um glacis se dá pela combinação da formação litológica, das condições climáticas e tectônicas. Somente a natureza do substrato não define a sua elaboração, pois o comportamento de uma mesma rocha difere em condições morfoclimáticas distintas. Para esses autores, os climas secos, com chuvas violentas e intermitentes são características favoráveis à formação do glacis e quando o clima se torna mais úmido ele tende a desaparecer, pois o intemperismo químico se torna mais intenso do que a morfogênese mecânica. Esses autores se utilizam também da palavra glacis.

PENTEADO (1970, 1974), afirma que os termos pedimento e glacis são complexos a partir da conceituação e terminologia, sendo assim, esta autora afirma que se pode empregar tanto a denominação pedimento como a de glacis. Essa autora ressalta ainda que os pedimentos situados fora das áreas secas são formas reliquiais, reflexo de condições climáticas passadas mais secas. 
Já na região de São Pedro, PENTEADO (1970) ressalta que as fases secas foram mais longas, pois a drenagem apresenta amplas e extensas superfícies planas intercaladas de degraus, indicando a atuação de oscilações de clima seco e úmido.

Para o presente trabalho optou-se por utilizar a denominação glacis, já que como afirma PENTEADO (op. cit.), as opiniões não chegam a ser conflitivas na essência, com base nas formas e nos processos atuantes.

DEMATTÊ \& HOLOWAYCHUK $(1977, a)$ interpretaram as coberturas arenosas espessas do glacis de São Pedro como materiais remanejados que o teriam recoberto antes mesmo da sua dissecação posterior. QUEIROZ NETO \& JOURNAUX (1978) acrescentaram que essas Areias Quartzosas originadas das espessas formações arenosas que recobririam o glacis sofreram retrabalhamentos posteriores. Essas coberturas arenosas apresentam duas sequências: a basal, constituída por cascalhos, areias e argilas estratificadas de origem fluvial e a superior, de areias não estratificadas e não consolidadas, homogêneas morfológica e granulometricamente e com elevado grau de seleção, o que os fez pensar em origem eólica.

Nesse sentido, DEMATTÊ \& HOLOWAYCHUK (op. cit.) alegam que a contribuição eólica aparece evidenciada no fato de haver uma quantidade decrescente de areia fina e muito fina e silte a partir do rio Piracicaba ao sul, em direção a Serra de São Pedro ao norte, sugerindo essa direção para os fluxos.

Todos esses autores discutiram essas coberturas, hoje Areias Quartzosas, mas quase nada assinalaram sobre a ocorrência e a gênese dos solos Podzólicos do setor mais dissecado ao sul e nem tampouco a respeito das relações, sobretudo das passagens laterais das Areias Quartzosas a esses solos, ou ainda sobre as relações deles com o modelado, no quadro da evolução do glacis de São Pedro, após sua esculturação inicial.

Entretanto, em trabalho recente, OLIVEIRA et al (1994) estudando sedimentologicamente o material de origem tanto das Areias Quartzosas como dos Podzólicos levantaram a possibilidade de ocorrência de uma mistura entre 
as formações Pirambóia e Botucatu, herdada do processo original de sedimentação transicional entre elas, pois os materiais analisados, inclusive a rocha alterada, apresentaram características físicas de ambas as formações, razão pela qual sugeriram filiação direta dessas coberturas aos arenitos, isto é, seriam provenientes da sua alteração e não de extensos remanejamentos areolares como o proposto anteriormente, por QUEIROZ NETO \& JOURNAUX (op. cit.).

Outro fato importante a assinalar é que OLIVEIRA (1992) constatou a presença de uma zona de transição nesse glacis, situada entre o seu setor mais preservado ao norte e o mais dissecado ao sul, onde se dá a passagem das Areias Quartzosas (AQ) para os Podzólicos Vermelho-Amarelos(PV). Essa passagem é marcada por um suave rebaixamento topográfico e pela ocorrência de perfis de solos cujo horizonte arenoso superficial situado logo abaixo do horizonte A apresenta numerosas bandas onduladas centimétricas a milimétricas, avermelhadas, contendo mais argila, contrastadas, subhorizontais, relativamente paralelas entre si e freqüentemente anastomosadas, coalescentes e mais espessas na base dos perfis. O horizonte com bandas onduladas encontra-se situado acima de um horizonte arenoso, sem bandas, profundo e com características similares às Areias Quartzosas do setor norte.

Durante a realização dos vários itinerários de campo para reconhecimento preliminar da presente área de estudo pôde-se observar que tais perfis com bandas onduladas ocorrem por quase toda a zona de transição e que se repete em todos os interflúvios vizinhos e paralelos entre si (Vermelho, do Meio e Samambaia), (NAKASATO, 1992; ALARSA, 1994) e que não permitiram a classificação dos perfis de solo onde ocorriam nem como Areias Quartzosas (AQ), nem como Podzólicos Vermelho-Amarelos (PV).

Pelo fato desses perfis aparecerem principalmente nessa zona de transição, mesmo nos interflúvios vizinhos, levantou-se a possibilidade de se tratar de solos intermediários entre as Areias Quartzosas e os Podzólicos VermelhoAmarelos, o que motivou o interesse em estudá-los. 
Levantou-se então, a hipótese inicial deste trabalho, a de que estes perfis poderiam conter evidências sobre a relação entre a pedogênese e a morfogênese na área, isto é, poderiam ser os primeiros indicadores de uma evolução morfopedogenética regressiva do glacis conforme o sugerido por aqueles autores, em direção à cuesta e resultante de dissecação pela rede de drenagem; a intensificação do entalhamento do glacis, hoje desfeito em interflúvios menores com as características já apresentadas, poderia estar relacionada à umidificação progressiva do clima que se seguiu durante todo o Quaternário (após a fase seca inicial Plio-Pleistocênica), ainda hoje atuante, mas que não teria arrasado totalmente o glacis, já que parte considerável da sua superfície encontra-se ainda pouco dissecada, portanto relativamente conservada.

Alguns registros de estudos desses solos foram encontrados, dentre eles alguns dos mais antigos sobre classificação dos solos do Estado de São Paulo, como no trabalho de SETZER (1949), onde o autor descreve os solos em questão como solos do grupo 11, para as Areias Quartzosas e solos do grupo 12, para os Podzólicos Vermelho-Amarelos, que ele chama de solos Pirambóia. As descrições foram realizadas através de características morfológicas observadas em campo e mais parecem um relato de viagem. Não foram realizadas análises em laboratório.

Mais tarde esses solos foram descritos e mapeados por BRASIL (1960), onde os autores apresentam as descrições morfológicas dos solos e nomenclaturas mais parecidas com as atuais, além de realizar análises físicas e químicas e discutílas. As Areias Quartzosas foram denominadas Regosol e os Podzólicos Vermelho-Amarelos de variação Laras. Fato importante é que eles já apontavam a ocorrência de solos intermediários que foram cartografados como Regosol intergrade para Podzólico Vermelho-Amarelo, mas não fizeram qualquer referência às bandas onduladas nas descrições morfológicas de campo; entretanto, já assinalaram o aparecimento desses solos quando o relevo tornase mais acidentado. 
Estudos específicos realizados por DEMATTÊ \& HOLOWAYCHUK (1977, a, b) e DEMATTÉ et al (1977) do ponto de vista granulométrico, químico, mineralógico e micromorfológico sobre oito perfis isolados, relativamente alinhados entre si, desde o rio Piracicaba até o reverso da Serra de São Pedro, denominados Pedons 1 a 8 e chamados de topossequência, embora sem filiação genética entre eles. As Areias Quartzosas correspondem aos Pedons 4 e 5 e o Podzólico mais próximo à área do presente estudo corresponde ao Pedon 3. A única referência às bandas onduladas aparece no Pedon 1, no terraço do rio Piracicaba e que corresponde ao Podzólico.

OLIVEIRA \& PRADO (1989) e OLIVEIRA \& MENK (no prelo) mapearam os solos da região de Piracicaba utilizando-se de dados morfológicos e analíticos, estudando também os perfis intermediários de solos na região de São Pedro e não só os perfis tipo. Foram os únicos autores, dentre os anteriormente citados, a se referirem claramente às bandas onduladas dos perfis Areias Quartzosas intermediária para Podzólico Vermelho-Amarelo da região de São Pedro, mesmo sem estudá-las do ponto de vista micromorfológico. Para os autores, na Carta Pedológica Semi-detalhada do Estado de São Paulo-folha de Piracicaba, os solos intermediários aparecem como Podzólicos Vermelho-Amarelos intermediários para Areias Quartzosas e apresentam bandas onduladas (ou lamelas) nos horizontes $A$ e parte superior do B. No entanto, não os cartografaram no interflúvio dos Ribeirões do Meio/Samambaia, área do presente estudo, onde sua presença foi por nós constatada, mas apenas no interflúvio dos Ribeirões do Meio/Vermelho a oeste da área, também na zona de transição do glacis mais preservado para a zona dissecada.

A EMBRAPA (1988) e PRADO (1995) também descrevem as características padrão das Areias Quartzosas e dos Podzólicos Vermelho-Amarelos, mas nada mencionam a respeito dos solos intermediários.

Os resultados mais significativos extraídos de cada autor em relação aos solos em questão são apresentados nos QUADROS 1, 2 e 3 adiante. 
Bandas onduladas já tinham sido estudadas em Marília e em Bauru (SP), onde foram interpretadas como testemunhos de transformação de um solo (Latossolo) em outro (Podzólico) muito diferente (CASTRO 1989; SANTOS 1995). Nessas duas áreas as bandas onduladas praticamente só ocorrem nos solos Podzólicos Vermelho-Amarelos e mostram filiação direta com os horizontes Bt por estarem ligadas a eles através de uma espécie de pedúnculo curvo e por apresentarem na sua base as mesmas características macro e micromorfológicas do $\mathrm{Bt}$, sobretudo associadas à presença de hidromorfia suspensa do topo desse horizonte $\mathrm{Bt}$ e da base do horizonte arenoso $\mathrm{E}$ sobreposto, tais como: mosqueamento por segregação de ferro, zonas de exportação de argila com volumes milimétricos a centrimétricos de areias lavadas residuais, feições de iluviação com e sem segregação de ferro etc. Foram interpretadas como herdadas parcialmente dos Bt degradado por ação dessa hidromorfia, que antes estaria mais alto nos perfis. Tal degradação integrava parte do sistema de transformação pedológica vertical e lateral de um latossolo num podzólico (CASTRO \& CURMI, 1987; CASTRO, 1989) associado à evolução morfopedológica dos platôs de Marília e Bauru, ligado ao aprofundamento do nível de base da drenagem atribuido igualmente ao clima mais úmido Quaternário (Tropical com duas estações alternadas).

Entretanto, em São Pedro, não se constatou em campo as mesmas características das bandas onduladas como daquelas áreas, principalmente porque as bandas não estão ligadas diretamente a um horizonte Bt subjacente através de um pedúnculo, como também este horizonte nem sequer aparece nítido e desenvolvido abaixo delas e nem tampouco há qualquer sinal de hidromorfia nos perfis.

As observações preliminares de alguns perfis permitiram então pensar em outra hipótese, a de que poderiam tratar-se de bandas de iluviação por translocações verticais sucessivas de argila. Sua coalescência e espessamento em profundidade sugeriam até mesmo a possibilidade de que já formariam uma espécie de Bt incipiente ou pouco desenvolvido. 
Com base no interesse despertado por essas feições, em 1993 foi organizado um curso de Análise Estrutural da Cobertura Pedológica vinculado à PósGraduação em Geografia Física da USP, ministrado pelos Profs. Drs. Alain Ruellan (parte teórica), René Boulet, Selma Simões de Castro e Rosely Pacheco Dias Ferreira (estes três últimos na parte prática de campo), dentro do programa CAPES X COFECUB Projeto 35/87 e 151/94, cujo resultado principal foi o mapeamento detalhado dos solos da vertente esquerda do Córrego do Retiro, através de topossequências e curvas de isodiferenciação. (FIGURA 5 e FOTO 2 adiante); essa área foi escolhida para o curso de treinamento justamente por apresentar esses perfis intermediários onde foram constatados esses tipos de bandas onduladas.

O mapeamento realizado através das topossequências colocou também em evidência de que tais perfis correspondem à passagem entre as $A Q$ e os $P V$, embora estes últimos sejam estreitos e pouco evoluídos no setor e integrem um sistema pedológico, que se estende da parte superior à inferior da vertente estudada, constituido por $A Q$ - $A Q$ intermediárias para $P V$ com bandas onduladas e os PV estreitos da média vertente, onde ocorre uma ruptura de declive. Na parte inferior, abaixo da ruptura da vertente, ocorre sistema constituido por Litossolos à montante e os Glei e aluviais à jusante.

Esses segmentos, superior e inferior, aparecem separados por uma ruptura côncava nítida, que se apresenta em forma de degrau estrutural.

As topossequências então estudadas mostraram também outras características interessantes para o estudo das evidências e causas do desaparecimento dos Podzólicos e aparecimento dos Litossolos associados ao degrau estrutural já citado. Este, entretanto, são objeto de estudos mais avançados (DIAS FERREIRA, 1997).

O sistema pedológico ora em estudo, restringe-se assim, ao segmento superior, isto é, à montante da ruptura de declive da vertente e estende-se do topo do interflúvio (da zona de transição) até o aparecimento do degrau estrutural com Litossolo. 
Muitas dúvidas foram levantadas a partir desse mapeamento, oriundas do fato de não se estar diante de um sistema pedológico morfologicamente bem definido e evoluído, nitidamente disposto em dois segmentos da vertente, e nem diante de perfis de solo passíveis de classificação simples, pois ainda apresentam, no que se refere ao segmento superior, uma passagem muito progressiva de um horizonte ao outro e de um solo ao outro pouco diferenciados entre si, cujas interpretações disponíveis não eram satisfatórias para explicar a morfologia encontrada.

Escolheu-se, então, a topossequência do segmento superior da vertente representativa do sistema com $A Q$ intermediária para $P V$, para 0 desenvolvimento da presente pesquisa.

Como os trabalhos anteriores não usaram a análise micromorfológica para esses perfis com bandas onduladas de modo evolutivo e nem para os Podzólicos Vermelho-Amarelos na área, optou-se por valorizar este tipo de estudo, visto que poderia fornecer importantes sinais sobre o comportamento e a organização dos constituintes dos horizontes e feições pedológicas existentes (sobretudo as bandas onduladas).

Assim, o trabalho realizado pretende contribuir com subsídios para a compreensão da pedogênese da zona de transição do glacis de São Pedro, no que se refere ao significado dos perfis de Areias Quartzosas com bandas onduladas e o aparecimento dos solos Podzólicos. 
QUADRO 1 - Síntese das características das Areias Quartzosas segundo vários autores

\begin{tabular}{|c|c|c|c|c|c|c|c|c|c|}
\hline Autor & $\begin{array}{l}\text { Denominação } \\
\text { empregada }\end{array}$ & $\begin{array}{l}\text { Porcentagem } \\
\text { de argila }\end{array}$ & $\begin{array}{l}\text { Porcentagem } \\
\text { de silte }\end{array}$ & $\begin{array}{l}\text { Porcentagem } \\
\text { de areia }\end{array}$ & $\mathrm{S}$ & $\mathrm{T}$ & $\mathrm{V} \%$ & $\mathrm{pH}$ & $\begin{array}{l}\text { Características } \\
\text { micromorfoló- } \\
\text { gicas }\end{array}$ \\
\hline $\begin{array}{l}\text { SETZER } \\
\text { (1949) }\end{array}$ & $\begin{array}{ll}\text { Solos } & \text { do } \\
\text { Grupo } 11 & \end{array}$ & baixa & baixa & |----------- & - & ----------- & ----------- & solos ácidos & --י-י-י-י-ים \\
\hline BRASIL (1960) & Regosol & 1 a $5 \%$ & 0,2 a $2,6 \%$ & $\begin{array}{l}93 \text { a } 98 \% \\
\text { (soma das } \\
\text { areias grossa e } \\
\text { fina) }\end{array}$ & $\begin{array}{l}0,26 \text { a } 0,60 \% \\
\mathrm{meq} / 100 \mathrm{~g}\end{array}$ & $\begin{array}{l}0,86 \quad \text { a } 4,34 \\
\text { meq/100g }\end{array}$ & 13,8 a $30,2 \%$ & $\begin{array}{l}\text {-em água= 4,6 } \\
\text { a } 5,5 \\
\text {-em } \mathrm{KCl}=3,9 \text { a } \\
4,3\end{array}$ & --------- \\
\hline $\begin{array}{l}\text { DEMATTÊ } \\
(1977)\end{array}$ & $\begin{array}{l}\text { Areias } \\
\text { Quartzosas }\end{array}$ & 4 a $10 \%$ & $<2 \%$ & $\begin{array}{l}>80 \% \text { de areia } \\
\text { fina }\end{array}$ & $\begin{array}{lcc}0,3 \quad \text { a } & 1,1 \\
\text { meq/100g } & \end{array}$ & $\begin{array}{lcl}1,5 \quad \text { a } & 6,8 \\
\text { meq/100g } & \end{array}$ & 3 a $13 \%$ & $\begin{array}{l}\text {-em água= 4,6 } \\
\text { a } 4,9 \\
\text {-em } \mathrm{KCl}=4,2 \text { a } \\
4,6\end{array}$ & $\begin{array}{l}\text { estrutura } \\
\text { plásmica } \\
\text { opaca }\end{array}$ \\
\hline $\begin{array}{l}\text { EMBRAPA } \\
(1988)\end{array}$ & $\begin{array}{l}\text { Areias } \\
\text { Quartzo- } \\
\text { sas (solos com } \\
\text { hor. C areno- } \\
\text { quart. e hor. A } \\
\text { fraco) }\end{array}$ & ------------ & |----------- & ------------ & --------- & |------------- & baixos teores & 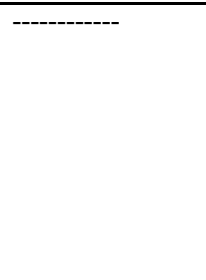 & ------------- \\
\hline PRADO (1995) & $\begin{array}{l}\text { Areias } \\
\text { Quartzosas }\end{array}$ & $\begin{array}{l}<15 \% \text { (argila + } \\
\text { silte) }\end{array}$ & $\begin{array}{l}<15 \% \text { (argila + } \\
\text { silte) }\end{array}$ & '---------- & ---------- & '---------- & $<50 \%$ & --------- & '---------' \\
\hline $\begin{array}{lr}\text { OLIVEIRA } & \& \\
\text { MENK } & \text { (no } \\
\text { prelo) } & \end{array}$ & $\begin{array}{l}\text { Areias } \\
\text { Quartzosas }\end{array}$ & $<15 \%$ & ---------- & $\begin{array}{l}>70 \% \text { (sendo } \\
\text { que } 55 \%=\text { areia } \\
\text { fina e } 35 \% \\
\text { areia grossa) }\end{array}$ & $\begin{array}{l}1,1 \text { meq/100g } \\
\text { de solo no hor. } \\
\text { superficial e } \\
0,6 \text { no hor. } \\
\text { subsup. }\end{array}$ & ---------- & ---------- & $\begin{array}{l}\text {-em água }=5,4 \\
\text { no horizont } \\
\text { sup. e } 4,9 \text { no } \\
\text { hor. subsup. }\end{array}$ & ---------- \\
\hline
\end{tabular}


QUADRO 2 - Síntese das características das Areias Quartzosas intermediárias para Podzólico Vermelho-amarelo segundo vários autores

\begin{tabular}{|c|c|c|c|c|c|c|c|c|c|}
\hline Autor & $\begin{array}{l}\text { Denominação } \\
\text { empregada }\end{array}$ & $\begin{array}{l}\text { Porcentagem } \\
\text { de argila }\end{array}$ & $\begin{array}{l}\text { Porcentagem } \\
\text { de silte }\end{array}$ & $\begin{array}{l}\text { Porcentagem } \\
\text { de areia }\end{array}$ & $\mathrm{S}$ & $\mathrm{T}$ & $\mathrm{V} \%$ & $\mathrm{pH}$ & $\mathrm{Ki}$ \\
\hline $\begin{array}{l}\text { SETZER } \\
\text { (1949) }\end{array}$ & ----------- & ---------- & --------- & ---------- & ------- & ---------- & ---------- & ---------- & ---------- \\
\hline BRASIL (1960) & $\begin{array}{l}\text { Regosol } \\
\text { intergrade para } \\
\text { Podzólico } \\
\text { Vermelho- } \\
\text { Amarelo }\end{array}$ & $<15 \%$ & $\mathrm{~B}=0,2$ a $2,3 \%$ & $\begin{array}{l}>60 \% \text { de areia } \\
\text { fina } \\
\text {-total }=71,5 \quad \text { a } \\
90 \%\end{array}$ & $\begin{array}{l}A=0,66 \text { a } 2,3 \\
\mathrm{meq} / 100 \mathrm{~g} \\
\mathrm{~B}=0,52 \text { a } 2,17 \\
\mathrm{meq} / 100 \mathrm{~g}\end{array}$ & $\begin{array}{l}\mathrm{A}=2,37 \text { a } 3,52 \\
\mathrm{meq} / 100 \mathrm{~g} \\
\mathrm{~B}=1,47 \text { a } 2,76 \\
\text { meq } / 100 \mathrm{~g}\end{array}$ & $\begin{array}{l}A=27 \text { a } 40 \% \\
B=60 \text { a } 80 \%\end{array}$ & $\begin{array}{l}\text {-em água= } 4,1 \\
\text { a } 5,7 \\
\text {-em } \mathrm{KCl}=3,9 \text { a } \\
5,0\end{array}$ & $\begin{array}{l}A=1,4 \text { a } 1,93 \\
B=1,31 \text { a } 1,93\end{array}$ \\
\hline $\begin{array}{l}\text { DEMATTÊ } \\
(1977)\end{array}$ & --------- & --------- & ------' & ------ & --------- & ------- & -------- & -------- & ------- \\
\hline $\begin{array}{l}\text { EMBRAPA } \\
(1988)\end{array}$ & |---------- & -------- & ------- & -------- & ------- & ------- & -------- & --------- & --------- \\
\hline PRADO (1995) & -------- & - & ----' & ------' & ----' & ----' & ----' & ------- & -------- \\
\hline $\begin{array}{lr}\text { OLIVEIRA } & \& \\
\text { MENK } & \text { (no } \\
\text { prelo) } & \end{array}$ & $\begin{array}{l}\text { Podzólico } \\
\text { Verm- Amarelo } \\
\text { distrófico, A } \\
\text { moderado, } \\
\text { intermediário } \\
\text { com AQ }\end{array}$ & baixa & ---------- & $\begin{array}{l}\text { arenoso } \\
\text { dominante }\end{array}$ & ----------- & --------- & ---------- & ---------- & ---------- \\
\hline
\end{tabular}


QUADRO 3 - Síntese das características dos Podzólicos Vermelho-Amarelos segundo vários autores

\begin{tabular}{|c|c|c|c|c|c|c|c|c|c|c|}
\hline Autor & $\begin{array}{l}\text { Denominação } \\
\text { empregada }\end{array}$ & $\begin{array}{l}\text { Porcentagem } \\
\text { de argila }\end{array}$ & $\begin{array}{l}\text { Porcentagem } \\
\text { de silte }\end{array}$ & $\begin{array}{l}\text { Porcentagem } \\
\text { de areia }\end{array}$ & $S$ & $\bar{T}$ & V\% & $\mathrm{pH}$ & $\begin{array}{l}\text { Caract. } \\
\text { Micromorfo- } \\
\text { lógicas }\end{array}$ & $\mathrm{Ki}$ \\
\hline $\begin{array}{l}\text { SETZER } \\
\text { (1949) }\end{array}$ & $\begin{array}{l}\text { Solos do Grupo } \\
12\end{array}$ & muito baixa & ---------- & ------- & ---------- & |-------- & '---------- & |--------- & --------- & ------ \\
\hline $\begin{array}{l}\text { BRASIL } \\
(1960)\end{array}$ & $\begin{array}{l}\text { Podzólico } \\
\text { Verm.-Amarelo } \\
\text { variação Laras }\end{array}$ & $\begin{array}{l}A=5 \text { a } 13 \% \\
B=15 \text { a } 29 \%\end{array}$ & $\begin{array}{l}A=2 \text { a } 6 \% \\
B=2 \text { a } 15 \%\end{array}$ & $\begin{array}{l}<10 \% \text { de areia } \\
\text { grossa }\end{array}$ & $\begin{array}{ll}A=< & 2 \\
m e q / 100 g & \end{array}$ & 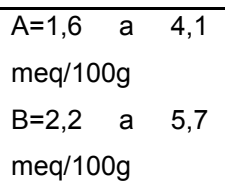 & $\begin{array}{l}40 \% \text { no hor. } A \\
\text { e }<40 \% \text { no hor. } \\
B\end{array}$ & $\begin{array}{l}\mathrm{A}=-\mathrm{em} \text { água }= \\
4,5 \text { a } 4,9 \text { e em } \\
\mathrm{KCl}=4,0 \text { a } 4,1\end{array}$ & ------ & $\begin{array}{l}B=1,8 \\
\text { a } 2,0\end{array}$ \\
\hline $\begin{array}{l}\text { DEMATTÊ } \\
(1977)\end{array}$ & $\begin{array}{l}\text { Podzólico } \\
\text { Verm.-Amarelo } \\
\text { variação Laras }\end{array}$ & $\begin{array}{l}7 \% \text { no hor. } A \text { e } \\
18 \% \text { no hor. } B\end{array}$ & ---------- & $\begin{array}{l}70 \text { a } 80 \% \text { de } \\
\text { areia fina }\end{array}$ & $\begin{array}{lcc}2,0 \quad a & 6,6 \\
\text { meq/100g } & \end{array}$ & $\begin{array}{l}A=4,9 \\
B=21,4\end{array}$ & $\begin{array}{l}A=5 \text { a } 11 \% \\
B=5 \text { a } 8 \%\end{array}$ & $\begin{array}{l}\text {-em água }=4,7 \\
\text { no hor. } \mathrm{A} \text { e4,8 } \\
\text { no hor. } \mathrm{B} \\
\text {-em } \mathrm{KCl}=4,1 \\
\text { nos hor. } \mathrm{A} \text { e B }\end{array}$ & $\begin{array}{l}\text { estruturas } \\
\text { plásmicas } \\
\text { esquelsépi- } \\
\text { ca e } \\
\text { silassépica }\end{array}$ & ------ \\
\hline $\begin{array}{l}\text { EMBRAPA } \\
\text { (1988) }\end{array}$ & 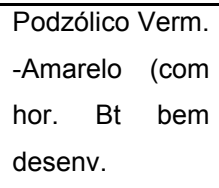 & 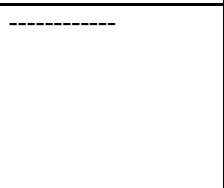 & 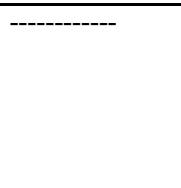 & 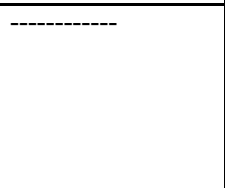 & 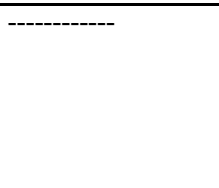 & 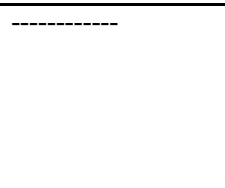 & alta ou média & ------- & 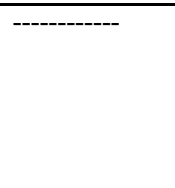 & ----- \\
\hline $\begin{array}{l}\text { PRADO } \\
(1995)\end{array}$ & $\begin{array}{l}\text { Podzólico } \\
\text { Vermelho- } \\
\text { Amarelo }\end{array}$ & ---------- & ----- & - ------ & - & --------- & - - & - --- & -- & 2,0 \\
\hline $\begin{array}{l}\text { OLIVEIRA \& } \\
\text { MENK (no } \\
\text { prelo) }\end{array}$ & $\begin{array}{l}\text { Podzólico Verm. } \\
\text {-Amarelo } \\
\text { unidade } \\
\text { Serrinha }\end{array}$ & $\begin{array}{l}4 \text { a } 21 \% \text { no hor. } \\
\text { A e } 14 \text { a } 35 \% \\
\text { no hor. B }\end{array}$ & 0 a $10 \%$ & $\begin{array}{l}\text { fina } A=31 \text { a } \\
93 \% \text { e } B=38 \text { a } \\
73 \% \\
\text { grossa } A=2 \quad \text { a } \\
62 \% \text { e } B=2 \quad \text { a } \\
38 \%\end{array}$ & $\begin{array}{l}A=0,3 \text { a } 6,8 \\
\text { meq/100g } \\
B=0,2 \text { a } 16,5 \\
\text { meq } / 100 \mathrm{~g}\end{array}$ & $\begin{array}{l}\mathrm{A}=1,4 \text { a } 7,7 \\
\mathrm{meq} / 100 \mathrm{~g} \\
\mathrm{~B}=1,8 \text { a } 17,9 \\
\text { meq } / 100 \mathrm{~g}\end{array}$ & $\begin{array}{l}A=12 \text { a } 88 \% \\
B=6 \text { a } 92 \%\end{array}$ & $\begin{array}{l}A=4,3 \text { a } 6,9 \mathrm{em} \\
\text { água } \\
B=3,8 \text { a } 6,2 \mathrm{em} \\
\text { água }\end{array}$ & |------- & 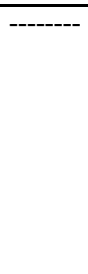 \\
\hline
\end{tabular}




\subsection{Objetivos do Trabalho}

O objetivo principal deste trabalho é caracterizar as organizações macro e micromorfológicas de uma topossequência contendo um sistema pedológico representativo do trecho montante da faixa de transição entre o setor mais preservado e a zona dissecada do glacis de São Pedro, SP.

Para tanto, pretende-se evidenciar as estruturas pedológicas presentes nessas duas escalas e suas interrelações, no sentido de fornecer subsídios para a compreensão da dinâmica pedogenética.

\section{3 Área de pesquisa}

\subsubsection{Localização}

A área de pesquisa localiza-se na Depressão Periférica Paulista, próxima ao contato com o Planalto Ocidental, no município de São Pedro-SP, na periferia

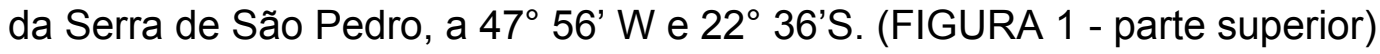
A vertente estudada localiza-se na zona de transição do glacis mais preservado para o mais dissecado, no interflúvio dos ribeirões do Meio e Samambaia, na vertente da margem esquerda da Bacia do Córrego do Retiro, alto curso do ribeirão homônimo, na região de São Pedro-SP. (FIGURA 1 - bloco diagrama inferior) 
FIGURA 1 - Localização da área de estudo
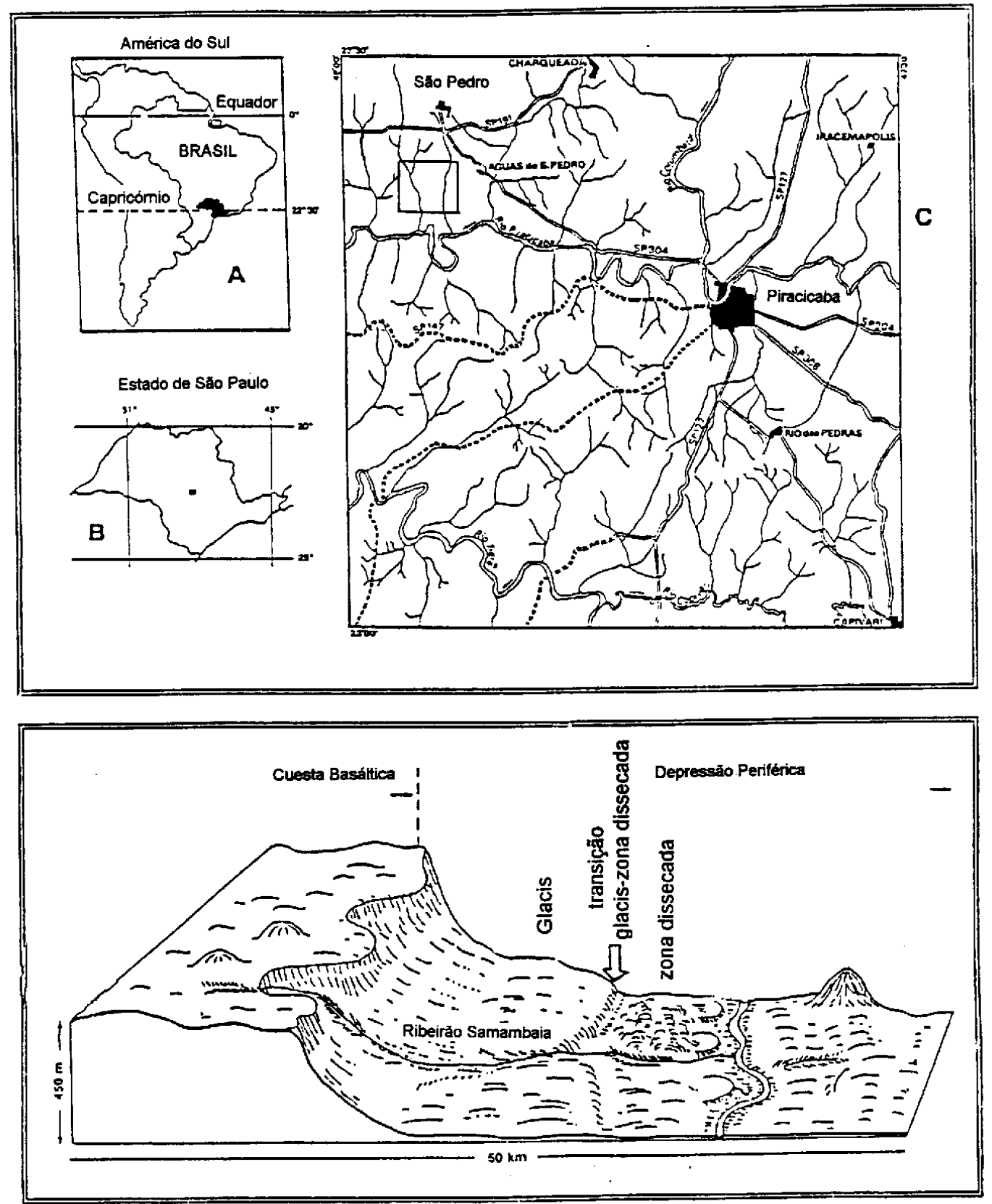

região de estudo

$§$ setor de estudo

FONTE: OLIVEIRA \& van den BERG, 1992 (adaptado por OLIVEIRA, D. de, 1996) 


\subsubsection{Geologia}

A área de estudo acha-se sobre trecho mapeado como Formação Pirambóia, de origem sedimentar, pertencente ao Grupo São Bento, do Mesozóico, na Bacia Sedimentar do Paraná.

A Formação Pirambóia compreende um conjunto de depósitos essencialmente arenosos, de ambiente fluvial, que repousa em discordância sobre os arenitos do Permiano; sua espessura máxima é superior a 300 m no Estado de São Paulo e sua idade vai do Triássico Inferior ou Médio ao Jurássico. (WU \& SOARES, 1974)

Entre o vale do rio Piracicaba ao sul e o sopé da escarpa da Serra de São Pedro, ao norte da área de estudo, ocorrem arenitos finos, com níveis sílticosargilosos lenticulares e estratificação geral plano-paralela atribuídos a origem flúvio-lacustre da Formação Pirambóia. (QUEIROZ NETO \& JOURNAUX, 1978) A designação "Pirambóia" foi utilizada por PACHECO (1927) citado por IPT (1981) para caracterizar um arenito avermelhado, sem cimento argiloso, com grãos rolados e que, segundo ele, constituem um andar (estrato) inferior ao arenito Botucatu.

OLIVEIRA (1930) citado por IPT (1981), procurando diferenciar os dois arenitos em relação às características litológicas também assinalou que o arenito Pirambóia nada mais é que a parte inferior do arenito Botucatu, não sendo preciso dar dois nomes à mesma formação.

ALMEIDA \& BARBOSA (1953), também citados por IPT (1981), admitiram que as duas formações representavam um único ciclo de sedimentação, refletindo condições climáticas que de quentes e úmidas evoluíram para desérticas. Distinguiram um membro inferior, o Arenito Pirambóia, de caráter predominantemente aquoso e outro eólico, compreendendo o Arenito Botucatu. No entanto, a partir dos trabalhos de SOARES (1973), a divisão estratigráfica em duas formações tornou-se a mais difundida no meio geológico e a maioria dos trabalhos mais recentes tratam da redefinição das características de cada 
pacote sedimentar, mantendo sempre o critério de divisão: Formação Pirambóia para sedimentos sub-aquosos da base e Formação Botucatu para sedimentos eólicos superpostos.

Os arenitos da formação Pirambóia apresentam 95\% de quartzo, sendo que os $5 \%$ restantes são feldspatos e micas (SOARES, op. cit.). Os minerais pesados são insignificantes, não chegando a $0,5 \%$, sendo que os mais comuns são a turmalina e a estaurolita. (BÓSIO, 1972)

Quanto aos parâmetros texturais, os sedimentos Pirambóia apresentam seleção média, assimetria negativa e maior variabilidade de granulometria, dada principalmente pela grande variação do diâmetro médio. (BÓSIO, 1973)

Segundo SOARES (op. cit.), correspondem a um pacote bastante espesso de arenitos de granulação fina a média, com estratificação cruzada, intercalado por camadas síltico-argilosas e argilosas com estratos plano-paralelos. É freqüente a presença de grânulos dispersos, assim como pelotas de argila. Apresenta coloração clara, predominando tons avermelhados e amarelados.

As variações litológicas e de estruturas sedimentares representam depósitos de ambiente continental úmido oxidante, predominando o fluvial, em canais meandrantes e planícies de inundação com pequenos depósitos lacustres. (IPT, 1981)

A base da Formação Pirambóia em São Pedro corresponde a uma superfície praticamente concordante com o plano de estratificação das camadas da Formação Estrada Nova do Permiano. (DUARTE, 1980)

\subsubsection{Geomorfologia}

A área de estudo situa-se na província geomorfológica da Depressão Periférica Paulista (ALMEIDA, 1964), próximo ao limite com a escarpa das Cuestas Basálticas, cujo topo marca o início do Planalto Ocidental e pertence à Zona do Médio Tietê no Estado de São Paulo. (IPT, 1981) 
Embora haja alguma controvérsia quanto à origem desta depressão, em geral admite-se que ela seja resultado de erosão diferencial, entre as rochas sedimentares, as rochas cristalinas e os basaltos, causada pela drenagem conseqüente e seus tributários subsequentes (PENTEADO, 1974; Ab'SABER, 1969; MELO \& PONÇANO, 1983), num período de tempo compreendido entre a deposição da Formação Itaqueri, correlativa da superfície do Japi (Eocênica) e a deposição da Formação Rio Claro (início do Pleistoceno), num intervalo de aproximadamente 40 milhões de anos. (in VIDAL TORRADO, 1994).

A área de estudo, conforme o assinalado, situa-se na zona do Médio Tietê onde, segundo o IPT (1981), predominam colinas médias, cujos interflúvios possuem topos aplainados com áreas de $1 \mathrm{a} 4 \mathrm{~km}^{2}$ e cujas vertentes apresentam perfis convexos a retilíneos.

A região de São Pedro apresenta vários compartimentos geomorfológicos locais que se distribuem de norte a sul desde a cuesta, localmente denominada de Serra de São Pedro e de Itaqueri, até o vale do rio Piracicaba. São eles: reverso da cuesta, escarpa, amplos interflúvios ou glacis, zona dissecada, terraços e várzea. (QUEIROZ NETO \& JOURNAUX,1978; COUTARD et al,1978)

Conforme o já exposto, em São Pedro, o glacis apresenta-se disposto como uma superfície orientada de Norte a Sul, onde a dissecação que se seguiu à sua esculturação deu origem à interflúvios alongados e paralelos entre si, que se estreitam progressivamente, tornando-se mais dissecados rumo à várzea do rio Piracicaba. (FIGURA 2)

O conjunto do glacis pode ser dividido em três setores conforme OLIVEIRA (1992) e como mostra na FIGURA 1 (bloco diagrama): o menos dissecado (amplos interflúvios), a transição para o mais dissecado e o mais dissecado (interflúvios estreitos, alongados e morrotes). 
FIGURA 2 - Hipsometria da área de estudo

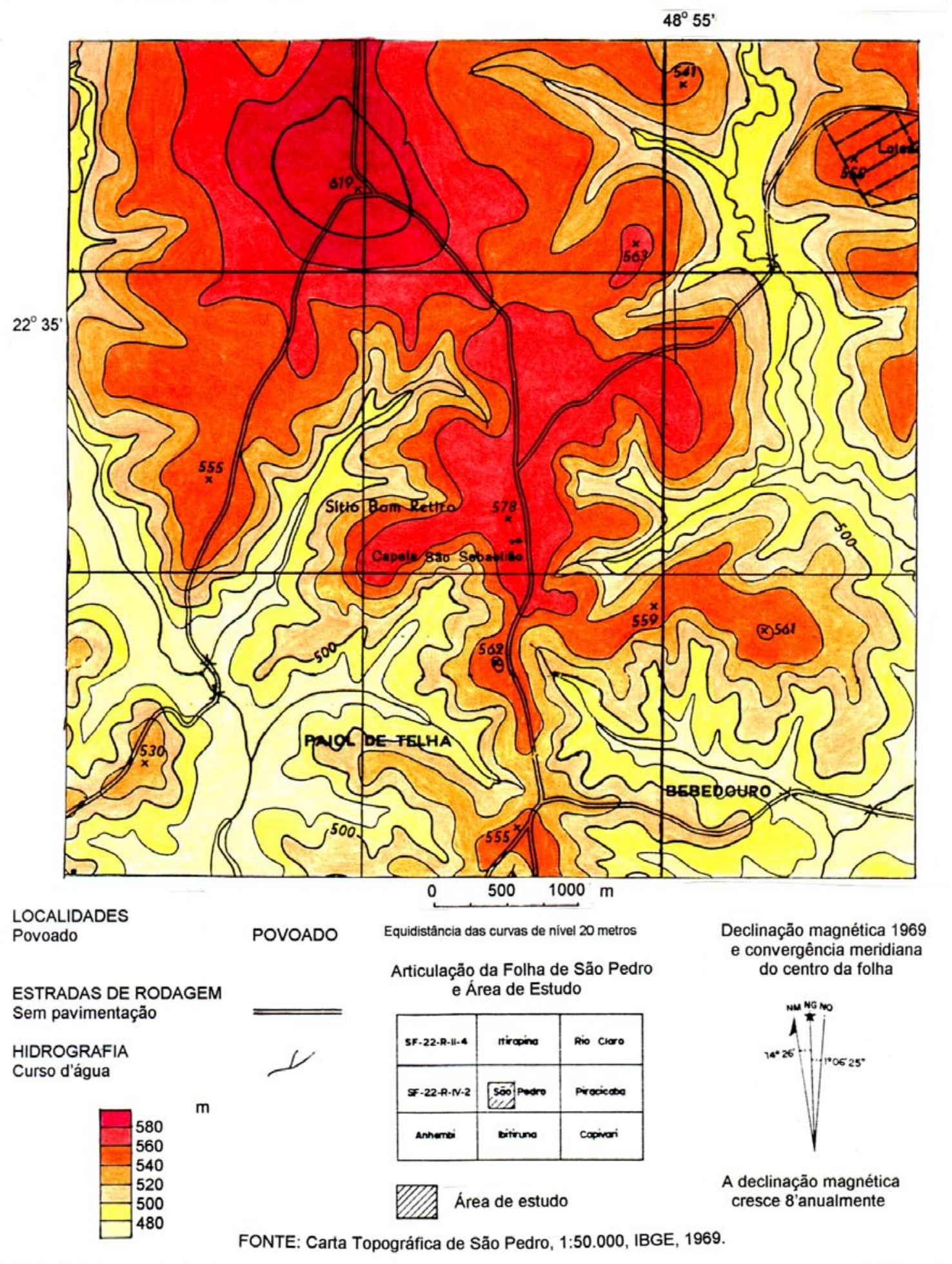


A área de estudo propriamente dita situa-se na passagem dos amplos interflúvios (glacis preservado) para a zona dissecada e aqui foi denominada de zona de transição glacis-zona dissecada, ou simplesmente zona de transição conforme pode-se verificar na hipsometria detalhada da FIGURA 2 e na morfologia detalhada representada na FIGURA 3 e comentada em seguida.

Os compartimentos presentes na área de estudo caracterizam-se como a seguir:

-o glacis (preservado): corresponde a uma superfície inclinada e muito suave que se estende do sopé da escarpa e se estende por 6 a $7 \mathrm{~km}$ em direção ao Rio Piracicaba, decrescendo de $620 \mathrm{~m}$ altitude até atingir cerca de $540 \mathrm{~m}$ na transição deste para a zona dissecada e com declividades que aumentam da ordem de 3 para 6\% (CAPELLARI, 1996).

Nesse mesmo sentido corta a série de arenitos e siltitos da formação Pirambóia, é recortado por poucos eixos de drenagem (os ribeirões Vermelho, do Meio e Samambaia) em largos interflúvios dispostos na direção Norte-Sul, com relevo suave e pouco dissecado e acha-se recoberto por uma espessa formação arenosa, as Areias Quartzosas, conforme o já exposto.

Os ribeirões Vermelho, do Meio e Samambaia, seus principais eixos de drenagem, em seu curso médio recortam os largos interflúvios desenvolvendo padrão subretangular, de baixa densidade e pouca energia de dissecação, ao contrário dos seus cursos alto (na Serra) e baixo (para o Vale do Rio Piracicaba), onde apresentam padrão dendrítico e forte poder de entalhamento. Os vales são muito abertos e em berço, com drenagem intermitente, terminando em grandes concavidades de declives suaves, como cabeceiras. (COUTARD et al, 1978)

Os cursos d'água principais e os trechos médio e inferior dos secundários tem escoamento perene. A drenagem intermitente vai aparecer com maior freqüência nas cabeceiras dos cursos secundários ( $3^{a}$ ordem). 
FIGURA 3 - Esboço morfológico da área de estudo e seu entorno

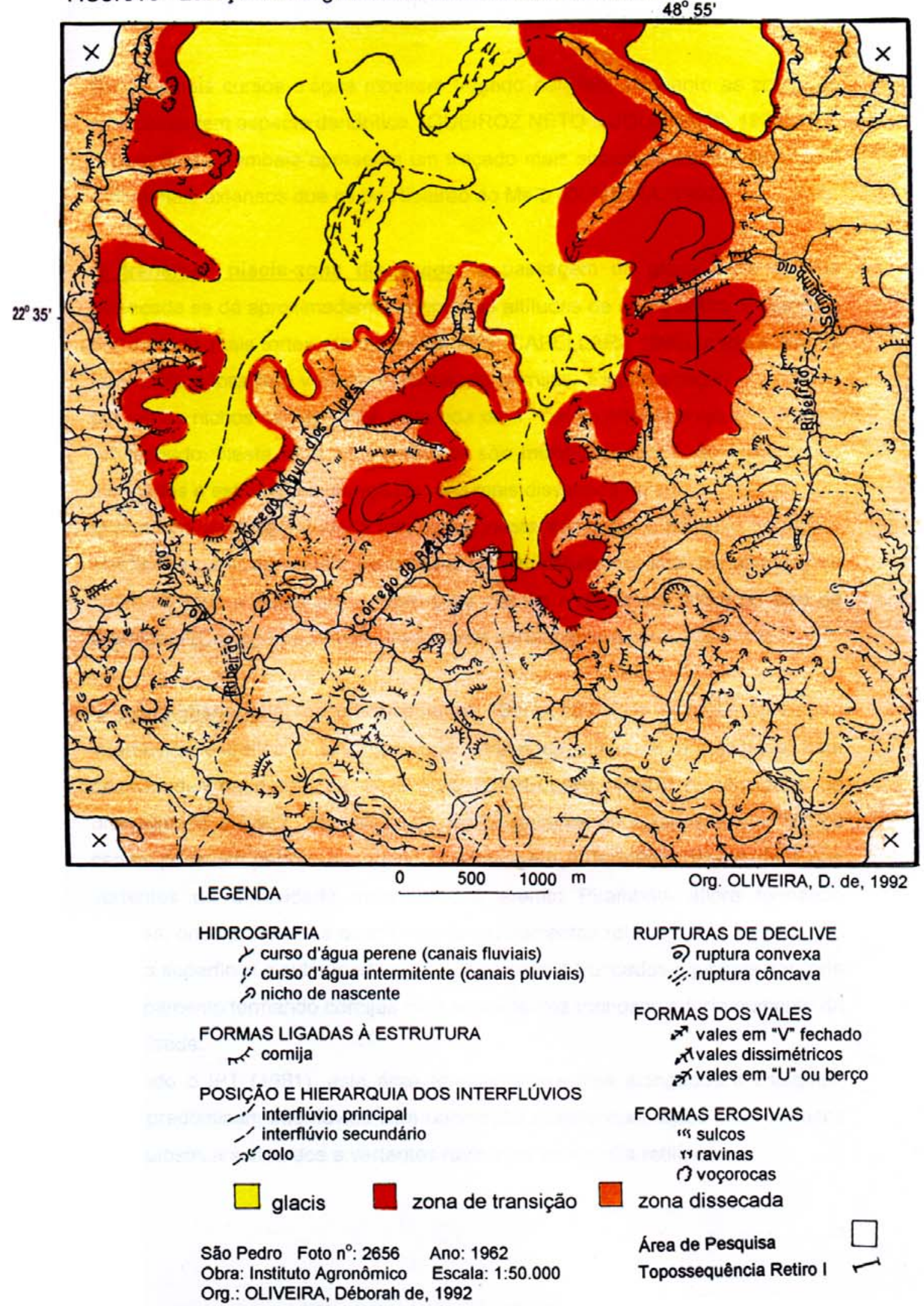


Os principais cursos d'água mostram traçado paralelo, enquanto as zonas de cabeceiras tem aspecto dendrítico. (QUEIROZ NETO \& JOURNAUX, 1978)

O ribeirão Samambaia apresenta um traçado mais sinuoso e canais de $1^{\mathrm{a}}$ e $2^{\mathrm{a}}$ ordem mais extensos que os do Ribeirão do Meio.(OLIVEIRA, 1992)

-a transição glacis-zona dissecada: a passagem do glacis para a zona dissecada se dá aproximadamente entre as altitudes de 540 e 500m. É marcada por declives mais fortes, da ordem de 20\% (CAPELLARI, 1996), onde o arenito Pirambóia aflora nas vertentes, formando cornijas. Essa transição é marcada por vários nichos de nascente, com rios de $1^{\text {a }}$ ordem intermitentes e vales em "V" fechado. Nesta faixa os interflúvios são muito recortados até tornarem-se alongados e estreitos em direção à zona mais dissecada ao sul.

O perfil da vertente estudada localiza-se nesta transição, é convexo no topo e côncavo a partir da ruptura de declive, com amplitude máxima das altitudes de $555 \mathrm{~m}$ no topo a $520 \mathrm{~m}$ até a ruptura de declive e desta até $465 \mathrm{~m}$ no eixo de drenagem (Córrego do Retiro), trecho este pertencente à zona dissecada.

-a zona dissecada: encontra-se entre 500 e 460m de altitude. Apresenta interflúvios estreitos e sinuosos, que variam de convexos a retilíneos, com declividades da ordem de 12 a 20\% (CAPELLARI, 1996). A densidade de drenagem é elevada, os vales são profundamente encaixados e em "V"; os canais possuem padrão dendrítico, a drenagem é de média densidade e nas vertentes de declividade mais forte, o arenito Pirambóia aflora formando cornijas, onde é comum a ocorrência de ravinamentos relacionados à circulação hídrica superficial e subsuperficial, freqüentemente truncados à jusante por forte escarpamento formando cornijas com afloramentos rochosos e forte aumento da declividade.

Segundo o IPT (1981), esta área apresenta morrotes alongados e espigões, onde predominam interflúvios sem orientação preferencial, topos mais estreitos e angulosos a achatados e vertentes ravinadas com perfis retilíneos. 
QUEIROZ NETO \& JOURNAUX (1978) também interpretaram o denominado por eles de glacis de São Pedro, como elaborado por pedimentação e o correlacionaram à primeira grande fase seca do Quaternário (Plio-Pleistoceno), após o que teria evoluído por dissecação pela rede de drenagem, adquirindo a fisionomia atual.

\subsubsection{Solos}

Os solos da região de São Pedro apresentam distribuição correlacionada aos compartimentos geomorfológicos já referidos. (FIGURA 4) Algumas características dos solos foram extraídas de OLIVEIRA \& PRADO (1989) e OLIVEIRA \& MENK (no prelo). As características referentes à transição glacis-zona dissecada foram extraídas de OLIVEIRA (1992) e permitiram constatar essa distribuição, conforme o apresentado a seguir:

-o glacis (preservado): neste compartimento dominam as Areias Quartzosas (AQ). São Solos álicos, essencialmente quartzosos, desenvolvidos sobre material de origem arenoso e relacionado com os arenitos da Formação Pirambóia. Sua fração areia é igual ou superior a $70 \%$, onde a areia fina é dominante (mais de $55 \%$ ) e a fração argila inferior a 15\%. Os minerais primários intemperizáveis são virtualmente inexistentes ou pouco relevantes. Apresentam horizonte A fraco, moderado ou até proeminente. São, em geral, muito espessos e de cor bruno-avermelhada (5YR 4/3,4/2) a bruno-escura (7,5YR 4/3,4/4).

-a transição glacis-zona dissecada: próximo à zona dissecada no interflúvio dos Ribeirões do Meio-Samambaia a espessura das Areias Quartzosas diminui e ocorre a sua substituição progressiva por Podzólico Vermelho-Amarelo, marcada pela presença de horizonte subsuperficial arenoso e espesso, com bandas onduladas intercaladas com lentes arenosas eluviadas, passando, na 
FIGURA 4 - Esboço pedológico da área de estudo e seu entorno

\section{$48^{\circ} 55^{\prime}$}

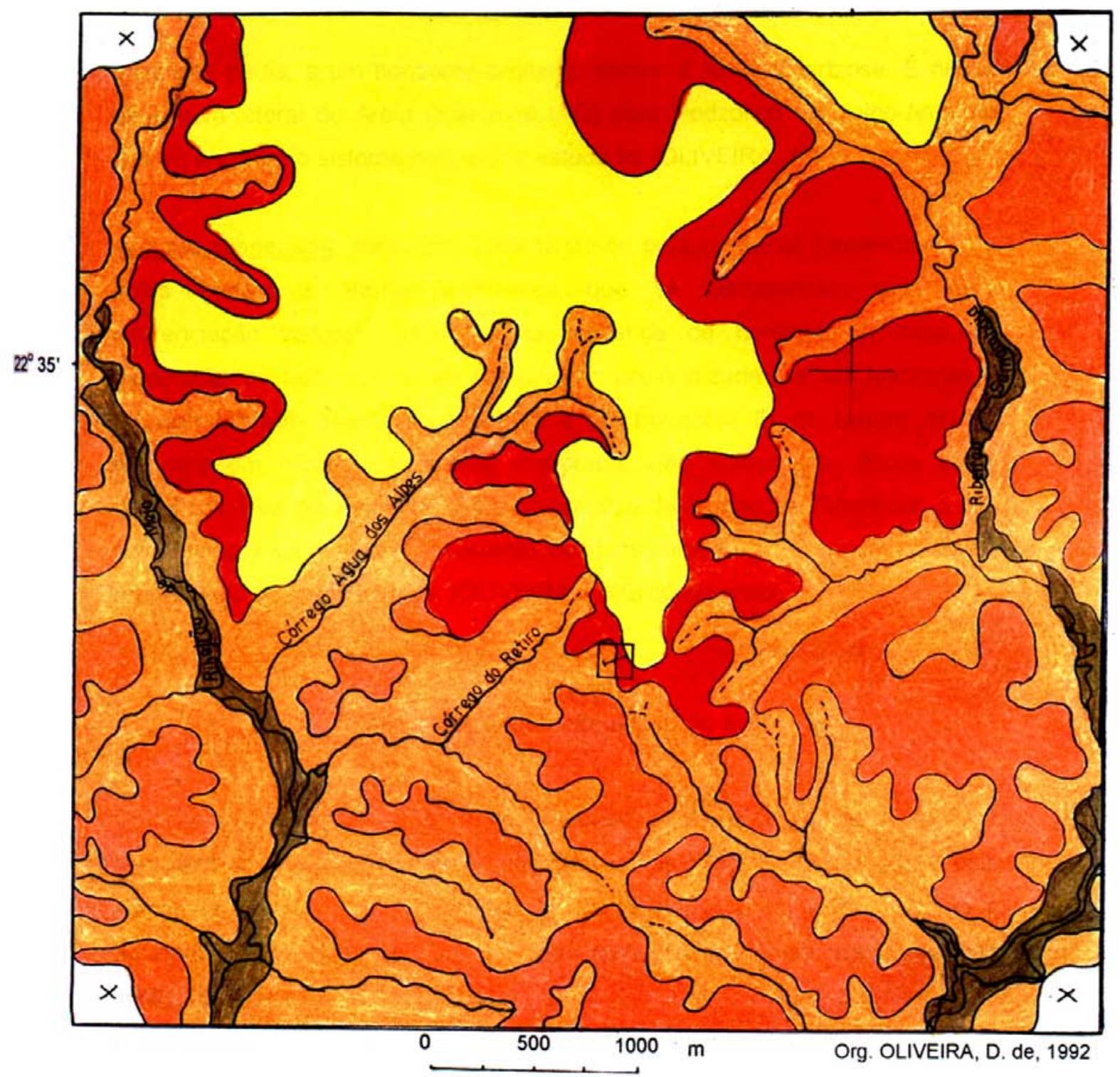

LEGENDA

$\square \mathrm{AQ}$ - Areia Quartzosa

$\square$ PV - Podzólico Vermelho-Amarelo

AQ/PV - Areia Quartzosa intermediária para Podzólico Vermelho-Amarelo

$\square$ PV/Li - Associação Podzólico Vermelho-Amarelo / Litólico

H - Solo Hidromórfico

São Pedro Foto $n^{\circ}: 2656$ Ano: 1962

Obra: Instituto Agronômico Escala: 1:50.000

Org.: OLIVEIRA, Déborah de, 1992
Área de pesquisa

Topossequência Retiro I 
base dos perfis, a um horizonte profundo similar à Areia Quartzosa. É nessa passagem lateral de Areia Quartzosa (AQ) para Podzólico Vermelho-Amarelo que se encontra o sistema pedológico estudado. (OLIVEIRA, 1992)

-a zona dissecada: esta zona caracteriza-se pela presença generalizada de solos Podzólicos Vermelho-Amarelos que se caracterizam pela forte diferenciação vertical, resultante da presença de horizonte $A$ fraco ou moderado, de textura arenosa seguido em profundidade por um horizonte $E$ (eluvial) também arenoso sobreposto a um horizonte Bt de textura média, estrutura em blocos, cerosidade moderada. São solos tanto álicos como distróficos e se desenvolvem sobre os arenitos da formações Pirambóia. Estes solos estão, muitas vezes, associados aos Litossolos Eutróficos, com horizonte A moderado ou chernozênico. (OLIVEIRA \& MENK, no prelo)

\subsubsection{Clima, Vegetação e Uso do Solo}

O clima na região de São Pedro, segundo a classificação de Köppen, é mesotérmico com inverno seco e a média anual de temperatura é de $20^{\circ} \mathrm{C}$ com amplitude térmica de $5,4^{\circ} \mathrm{C}$. A pluviosidade média anual é de $1368 \mathrm{~mm}$ e apresenta duas estações bem definidas com predominância das chuvas no verão. (CONTI, 1971)

A vegetação original da Depressão Periférica era a Floresta Latifoliada Tropical Semidecídua, relacionada à natureza dos solos que são, na maioria, de textura leve (arenosos) e com pequena capacidade de retenção de água. (BRASIL, 1960)

Na região de São Pedro a mata ocorre apenas na borda da escarpa da cuesta. No glacis, ocorria o cerrado, hoje em manchas residuais. Atualmente predominam o campo antrópico, as pastagens e ainda culturas de cana, além de 
algumas ocorrências de cítricas, concentradas nas proximidades do rio Piracicaba.

\subsection{Bases conceituais e metodológicas adotadas: revisão bibliográfica}

Para o desenvolvimento da pesquisa foi necessário adotar uma metodologia que trouxesse respostas quanto a filiação genética entre as Areias Quartzosas e os Podzólicos Vermelho-Amarelos através dos perfis intermediários com bandas onduladas. Para tanto, foi adotado o conceito de cobertura pedológica e como metodologia a Análise Estrutural da Cobertura Pedológica, expostos a seguir.

\subsubsection{A Cobertura Pedológica: conceitos, bases para seu estudo e tipos de evolução}

O solo é um meio dinâmico, em perpétua evolução dos constituintes, das estruturas, do sistema poroso. Há no interior do solo transferências de matéria, tanto sólida, como líquida, gasosa e biológica, vertical e lateralmente. Essas transferências se dão desde a escala dos microporos até o nível da bacia elementar. Assim, o solo constitui um corpo contínuo, denominado cobertura pedológica. (RUELLAN, 1984/85)

A cobertura pedológica é, portanto, um meio organizado, estruturado, formado por constituintes minerais e orgânicos e que estão dispostos entre si vertical e lateralmente, dando ao solo uma morfologia, uma anatomia, que pode ser observada e descrita em diferentes escalas, desde a microscópia até a da paisagem. (RUELLAN, op. cit.)

Nesse sentido, para estudar a cobertura pedológica é necessário conhecer a natureza dos constituintes, além de observar, medir, representar e interpretar as organizações morfológicas nas escalas de observação anteriormente citadas. 
Para tanto, RUELLAN et al (1989) destacam a importância do conhecimento dos quatro tipos de estruturas que correspondem à quatro escalas diferentes de organização da cobertura pedológica, da microescala até a paisagem. São elas: as organizações elementares, que se expressam sob a forma de agregados, poros, concentração de constituintes, cores e modificações devido as atividades biológicas, passando para as assembléias, que se caracterizam pelo conjunto de organizações elementares (torrões), os horizontes, que são os volumes pedológicos (conjunto dos torrões), até os sistemas pedológicos, que representam a organização dos horizontes e seu arranjo vertical e lateral no interior da unidade do relevo estudada (interflúvios, bacias de $1^{\text {a }}$ ordem).

Segundo CHAUVEL (1979), em cada um desses níveis, o estudo pedológico requer técnicas de observação próprias. Para as organizações elementares e assembléias predominam técnicas de observação de microscopia óptica, isto é, da micromorfologia; para os horizontes e sistemas pedológicos predomina o uso da observação e descrição de perfis de solo no campo, isto é, da macromorfologia.

Essas duas técnicas de observação foram empregadas na realização do presente trabalho, mas convém ressaltar que nenhuma das duas prescindiu de análises laboratoriais convencionais, o que também foi considerado e que, dada a relação entre elas, é necessário confrontá-las de modo a obter-se a compreensão nas diferentes escalas.

No interior da cobertura pedológica de uma unidade de relevo, os sistemas pedológicos são o conjunto estruturado de horizontes pedológicos, distribuídos no espaço e no tempo e que ocorrem dispostos entre si, ao longo das vertentes, de montante à jusante (SOUBIÈS \& CHAUVEL, 1984-85).

Se esses horizontes são mais ou menos concordantes com as superfícies externas que as modelaram eles têm relação direta com a última fase da morfogênese e estão em equilíbrio dinâmico com o meio. Entretanto, se as condições do meio se modificam no espaço e no tempo, o suficiente para que as condições pedobioclimáticas se tornem instáveis, eles se transformam para dar 
lugar às novas estruturas e se reequilibram em acordo com as novas condições pedobioclimáticas. Essas transformações originam horizontes pedológicos lateralmente discordantes em relação aos horizontes da cobertura inicial e avança lateralmente, mas em geral, são concordantes com as topografias das vertentes atuais, em especial nos seus terços médio e inferior. São os chamados sistemas de transformação pedológica lateral, que correspondem à transformação de uma cobertura pedológica inicial em outra, frequentemente muito diferente. (a partir de BOULET et al, 1984)

Os horizontes e seu arranjo lateral (a sua geometria) podem ser reconstituídos mediante a análise bidimensional da cobertura pedológica em campo, conforme o preconizado por BOULET et al (1982 a, b) e sua representação cartográfica requer uma síntese que expressa a tridimensionalidade das estruturas. (BOULET et al, $1982 \mathrm{c}$ ).

Os procedimentos empregados, denominados Análise Estrutural da Cobertura Pedológica, numa primeira etapa, consistem em examinar bidimensionalmente a cobertura pedológica através de topossequências, que correspondem a transectos dispostos de montante à jusante na linha de maior declive da vertente, ao longo dos quais são realizadas sondagens sucessivas e abertas trincheiras, à montante, na média vertente e à jusante, com interpolações entre esses pontos, no sentido de observar as transições verticais e laterais entre os horizontes e seu arranjo, reconstituindo sua morfologia geral, por aproximação geométrica. Posteriormente, a representação espacial desses volumes pedológicos se dá através de uma carta sintética, com isolinhas que identificam o aparecimento ou desaparecimento de volumes pedológicos, chamadas de curvas de isodiferenciação e que representam o sistema pedológico no plano.

O conhecimento das estruturas ou escalas de organização, desde as organizações elementares até o sistema pedológico permite o conhecimento da sua hierarquia, isto é, da ordem na qual as organizações aparecem no espaço e da sua cronologia, que corresponde à ordem em que as organizações aparecem no tempo, tanto para as organizações macro como micromorfológicas 
(CHAUVEL, 1979), contribuindo para a elucidação dos processos genéticos. Permite também uma certa previsão quanto a evolução dos solos, em função das condições ambientais atuais e das modalidades de utilização e organização do espaço. (RUELLAN et al, 1989)

Essas concepções nos estudos de pedogênese e morfogênese representaram uma mudança no paradigma ligado ao perfil de solo relativamente isolado (pedon) para o de cobertura pedológica e apareceram inicialmente nas pesquisas realizadas por pedólogos franceses na África: RUELLAN (1970), BOCQUIER (1973), BOULET (1974), CHAUVEL (1976), dentre outros. Mais tarde, na Guiana Francesa (BOULET, 1977) e também no Brasil, desde a década de 80 , nos trabalhos realizados por um grupo de pesquisadores brasileiros e franceses coordenados por QUEIROZ NETO e RUELLAN trabalhando em Marília, Bauru e Guaíra, no Estado de São Paulo, dentre outras áreas, resultaram em numerosos trabalhos: MONIZ (1980); CARVALHO et al (1983); LUCAS et al (1984); CHAUVEL et al (1983); SOUBIÈS et al (1983); SOKOLONSKI (1985); FERNANDES BARROS (1985 e 1996); CASTRO (1989); SALOMÃO (1994); SANTOS (1995); LADEIRA (1995); KERTZMAN (1996); CUNHA (1996) dentre outros, além de outros trabalhos desenvolvidos com apoio dos programas de pesquisa coordenados por MELFI e/ou BOULET, como: NICOLA (1993); NASCIMENTO (1993) e FILIZOLA (1994), que mostraram claramente as vantagens do novo modo de estudar o solo para compreensão da sua gênese e evolução.

De acordo com vários desses trabalhos anteriormente realizados, BOULET et al (1984) observam que há dois tipos de sistemas pedológicos de transformação lateral (transformação de um solo em outro), levando-se em conta a importância das transferências laterais internas e o estado dos produtos transportados: sistemas de tranformação sem transferência lateral interna e sistemas de transformação com transferência lateral interna de matéria (BOULET et al, 1984). 
Um dos exemplos dos primeiros trabalhos merece referência especial, como a seguir, dadas as hipóteses levantadas no presente estudo.

Corresponde ao sistema de transformação com transferência lateral interna (sistema eluvial-iluvial) estudado por BOULET (1974) em Garango, Alto Volta (África), onde se distingue: um domínio caulinítico à montante, constituído por um solo ferralítico vermelho, onde o estudo microscópico mostrou que este solo se forma por transformações sucessivas (mineralógicas e estruturais) a partir da rocha-mãe subjacente e um domínio mediano arenoso (lixiviado), separado do primeiro, mas que se desenvolve a partir dele evidenciado pela presença de relíquias. Neste domínio há uma separação do plasma caulinítico-ferruginoso, que é exportado para a base, onde se acumula num domínio argiloso à jusante, caracterizado morfológica e geoquimicamente como iluvial. Há horizontes em língua que são alimentados por um transporte lateral em suspensão originado da lixiviação. Estes desequilíbrios foram atribuídos à variações do nível de base por modificações climáticas que introduziram à variações da vegetação e a um regime hídrico do solo mais contrastado, provocando as primeiras separações plasma-esqueleto.

Os estudos desses sistemas de transformação mostram que estão em desequilíbrio com as paisagens atuais e que podem se encontrar em diferentes fases de evolução, isto é, desde os que estão em fase inicial de transformação até os que atingiram um novo equilíbrio (re-equilíbrio) de acordo com as condições climáticas atuais.

No Brasil, em regiões de clima tropical com estações alternadas, os estudos de sistemas pedológicos mostram que as condições morfopedológicas atuais frequentemente colocam as coberturas espessas, em geral latossólicas, em desequilíbrio, permitindo a mobilização interna de material vertical e lateralmente ao longo das vertentes.

Nos sistemas de transformação eluvial-iluvial estudados no Brasil, de modo geral, quando a cobertura inicial é latossólica, observa-se que a transformação consiste na separação do esqueleto e do plasma caulinítico-ferruginoso, 
influenciada pela circulação hídrica vertical e lateral, que promove a exportação do plasma no rumo jusante, onde se acumula. Isso faz com que a drenagem interna torne-se cada vez mais interrompida para jusante, pela diminuição da porosidade e aumento do plasma e também acarrete mudanças na estrutura, que passa de microagregada à montante para poliédrica à jusante. Essas transformações inicialmente lembraram as observadas na vertente estudada, apesar de lá não ocorrem solos Latossolos e sim Areias Quartzosas na posição de topo.

\subsubsection{Algumas interpretações sobre a origem das Areias Quartzosas, das bandas onduladas e dos horizontes $\mathrm{Bt}$}

De acordo com BRASIL (1960), as Areias Quartzosas são solos que estão distribuídos em várias manchas descontínuas e em diferentes áreas no Estado de São Paulo, tanto no Planalto Ocidental, como na Depressão Periférica e no litoral. Esses solos geralmente ocupam partes mais baixas do relevo, em depressões ou beira dos rios, podendo ser encontrados rodeando morros ou afloramentos do arenito, onde nota-se a influência direta do material de origem na sua formação. O relevo dominante é plano ou suavemente ondulado.

OLIVEIRA et al (1992) afirmam que as Areias Quartzosas faziam parte de uma mesma classe de solos denominada Regossolos e que foi modificada na década de 60, quando houve o desmembramento dessas duas classes. A única diferença entre essas classes de solos está no teor de minerais primários intemperizáveis, inexistentes nas Areias Quartzosas e mais elevado nos Regossolos.

Ainda segundo OLIVEIRA et al (op. cit.), as Areias Quartzosas são solos minerais, às vezes orgânicos na superfície, hidromórficos ou não, geralmente profundos, essencialmente quartzosos, com textura arenosa, variando entre mais grosseira ou mais fina com ausência de minerais primários 
intemperizáveis. Nestes perfis o máximo de argila atinge 15\%, quando se tem zero de silte e o máximo deste vai a $30 \%$ quando se tem zero de argila. Ainda segundo esses autores, as Areias Quartzosas são solos que podem apresentar horizonte A moderado ou fraco, raramente proeminente ou turfoso, seguindo-se um horizonte $\mathrm{C}$ solto e muito friável e pouco diferenciado. São solos geralmente álicos ou distróficos, com baixa capacidade de retenção de cátions (raramente atingindo $2 \mathrm{meq} / 100 \mathrm{~g}$ de solo), mesmo no horizonte $A$, sendo que os valores diminuem em profundidade, atingindo menos de 0,5 meq/100g de solo. Quando há uma tendência ao aparecimento de um horizonte $B$ incipiente, estes solos já podem ser considerados intermediários para Latossolos, para Podzólicos, para Plintossolos ou para Podzols, dependendo das áreas onde se encontram.

Na região de São Pedro, as Areias Quartzosas também aparecem associadas a outros solos, como aos Latossolos e aos Podzólicos, recebendo a denominação dada por OLIVEIRA \& MENK (no prelo) de Grupamento indiferenciado Latossolo Vermelho-Amarelo e Podzólico Vermelho-Amarelo intermediário com Areias Quartzosas e aparecem no interflúvio dos ribeirões Vermelho/ do Meio, interflúvio vizinho à presente área de pesquisa, conforme o já exposto. Segundo o autor, as bandas onduladas aparecem somente nas Areias Quartzosas associadas aos Podzólicos, como o que foi por nós observado na presente área de pesquisa, no interflúvio dos ribeirões do Meio/ Samambaia.

As Areias Quartzosas da região de São Pedro, segundo OLIVEIRA \& MENK (no prelo) são originadas dos arenitos da Formação Pirambóia, do Grupo São Bento. São solos arenosos, sendo a fração areia fina a mais abundante, em média $56 \%$ no horizonte superficial e 55\% no horizonte subsuperficial. A fração areia grossa é a segunda em abundância, com cerca de 35\% e 32\% respectivamente para esses dois horizontes. A fração argila tem valor médio de $9 \%$ e 13\%, também respectivamente para esses dois horizontes.

Entretanto, em São Pedro, as formações arenosas, material de origem das Areias Quartzosas que recobrem o glacis, têm recebido denominações diversas, como: sedimentos neo-cenozóicos, depósitos modernos, Formação Rio Claro 
etc. Possuem duas sequências: a basal, constituída por cascalhos, areias e argilas estratificadas e à vezes consolidadas de origem fluvial e a superior, constituída de areias não estratificadas e não consolidadas e que corresponde às Areias Quartzosas. (COUTARD et al, 1978)

DEMATTE \& HOLOWAYCHUK (1977, a, b) caracterizaram as Areias Quartzosas de São Pedro como formadas a partir da Formação Rio Claro. Para esses autores esses solos apresentam teor de argila variando entre 4\% e 10\%, sendo que a fração areia fina é predominante. Ainda segundo esses autores, as Areias Quartzosas são solos altamente intemperizados, pois têm sido expostos ao intemperismo desde que o material da Formação Rio Claro foi depositado. Quanto à micromorfologia desses solos, os autores observaram que a estrutura do plasma é opaca sob luz polarizada para todos os horizontes, devido à constância na composição mineralógica e granulométrica. Há predominância de caulinita (em torno de $80 \%$ ) e de quartzo como indicativos de elevado intemperismo. A estrutura de base desses solos, segundo os autores é granular (BREWER, 1964), isto é, grãos de esqueleto sem plasma ou com plasma sob a forma de agregados e que corresponderiam à estrutura denominada por STOOPS \& JONGERIUS (1975) de enáulica (aglomeroplásmica cf BREWER, 1964).

SUGUIO \& COIMBRA (1976) afirmam que o problema da gênese das bandas onduladas é ainda bastante controvertido. Segundo esses autores, a existência de bandas onduladas salientes intercaladas por partes reentrantes no horizonte A é explicável pelas pequenas diferenças em composição dos teores de argila, $\mathrm{CaCo}_{3}$, óxido de ferro etc. Segundo esses autores, o aparecimento dessas faixas alternantes é explicável por pequenas descontinuidades litológicas préexistentes que pela atuação dos processos pedogenéticos, foram apenas realçadas. 
CASTRO (1989) e VIDAL TORRADO (1994) fizeram longas revisões sobre o que dizem os autores a respeito dos processos formadores de bandas onduladas, conforme o resumido a seguir.

DIJKERMAN et al (1967) já ressaltavam que os solos com bandas onduladas não são somente formados por acumulação de argila nas bandas, mas em diferentes casos sugerem além da iluviação de argila, a formação de argila in situ, a ação do gelo e a sedimentação durante a formação do material de origem.

Segundo eles, vários pesquisadores têm explicado a acumulação de argila nas bandas onduladas por processos rítmicos, pela ação da floculação dos óxidos de ferro livre ou carbonatos nas partes baixas do perfil, por algum tipo de precipitação química periódica do ferro, com subsequente floculação da argila, por evapotranspiração da frente úmida ou por peneiramento em camadas de porosidade fina. Para esses autores, o fluxo de água carrega partículas em suspensão pela ação da gravidade e peneiramento formando uma banda incipiente que acaba sendo uma barreira para o movimento da água descendente, dado pelo entupimento dos poros de baixo para cima e, subconsequentemente, acarretando o aumento da espessura da banda.

QUEIROZ NETO (1975), estudando bandas onduladas em Marília, Presidente Prudente e Lucélia, no Estado de São Paulo, interpretou sua origem por processos de coluvionamento contínuo, agindo sobre material bastante homogêneo, mas apresentando pequenas variações de intensidade e ritmo, sendo responsável pela formação das bandas onduladas. A alternância de deposições ligeiramente mais argilosas e mais arenosas e processos pedológicos, sobretudo relacionados com migração de colóides (argila e ferro) e ação da vegetação, traria à superfície as bases trocáveis pelo sistema radicular, que são parcialmente lixiviadas mas retidas nas bandas onduladas ou no horizonte Bt.

Experimentos em laboratório foram realizados por BOND (1986), onde o autor reproduz a formação das bandas onduladas por processos de iluviação e a 
subsequente deposição de argila, concluindo que: 1) as bandas são muito semelhantes às encontradas em campo; 2)a dispersão da argila e sua deposição ocorre por obstrução dos poros finos ou quando se excede o máximo de concentração de argila em suspensão; 3)a formação das bandas ocorre simultaneamente ao longo do perfil; 4)o tempo para a formação das bandas deve ser curto; 5)a velocidade de transporte do material deve ser curto; 6)uma baixa porcentagem de argila $(<1 \%)$ já pode ter efeito nos solos arenosos.

Outros autores explicam a formação das bandas por iluviação de argilas e bioturbação em bandas estudadas na Nova Zelândia (KEMP \& McINTOSH, 1989). Esses solos sofreram sucessivas acumulações de sedimentos eólicos e translocações de argila por canais biológicos misturando os materiais dos horizontes superficiais e subsuperficiais através desses canais, não chegando a atingir as bandas de profundidade.

No trabalho de CASTRO \& CURMI (1987) e CASTRO (1989), realizado em Marília-SP, as bandas onduladas foram interpretadas como estruturas de acumulação dupla associadas ao processo de e-iluviação, sendo sua parte inferior herdada dos horizontes subjacentes $(\mathrm{Bt})$ e a superior herdada do bloqueio consequente da drenagem pelo entupimento dos poros abaixo, cuja água posterior trouxe em suspensão novas argilas mobilizadas de cima (do horizonte E) e que se depositaram no contato com o Bt; posteriormente pela hidromorfia, resultante do bloqueio de drenagem, toda a parte fortemente iluviada do topo do Bt sofre a dissociação ferro/argila e desencadeia-se sua eluviação por lessivagem da argila e lixiviação do ferro que ocorrem em ritmos diferentes (as argilas são mais rápidas) causando a formação de bolsões de areia lavada que coalescendo "isolam" as bandas. Nesse caso, os autores asssinalam que a eluviação é mais importante que a iluviação e as bandas são restos do $\mathrm{Bt}$, de quando ele estaria mais alto nos perfis antes de se degradar por hidromorfia, transformando-se em horizonte $\mathrm{E}$ com bandas, muitas delas ainda ligadas ao Bt em forma de pedúnculo. 
ROLIM NETO \& SANTOS (inédito) estudando bandas onduladas das Areias Quartzosas do agreste de Pernambuco interpretaram as bandas superficiais como mais antigas do que as subsuperficiais, obedecendo a seguinte sequência: intensa percolação da água que carregaria toda a argila inicial para as partes mais profundas do perfil; subsequentes precipitações formariam lençol freático que ao subir de nível no perfil traria as argilas dispersas em suspensão; parte superficial do lençol freático, ao sofrer pequenas evaporações causaria a formação incipiente de cutãs em alguns poros ou associados à superfície dos grãos; esta formação de cutãs serviria para ativar o processo de peneiramento, facilitando ainda mais o crescimento das bandas, quando lençóis freáticos subsequentes fossem formados.

Esses autores ressaltam que micromorfologicamente, a diferença existente para os horizontes que as contêm é a presença de argila preenchendo a porosidade de empilhamento simples, de forma total ou parcial, formando pontes entre os grãos de esqueleto, como CASTRO (1989) também observou mas apenas para a parte superior das bandas. Em certas partes, estes preenchimentos apresentam-se intactos e em outras bastante fragmentados, na forma de pápulas isoladas. Segundo esses autores, todos os revestimentos e preenchimentos, na forma de cutãs apresentam intensa manifestação de anisotropia ótica, típica da organização dos cutãs provenientes de iluviação.

Cabe aqui ressaltar que os cutãs são as feições pedológicas mais comuns nas bandas onduladas e consistem em concentrações plásmicas (que são os cutãs formados por iluviação e difusão de plasma) ou separações plásmicas (que são os cutãs formados por modificações ou rearranjos in situ) associadas às superfícies naturais do solo, às paredes dos torrões, dos grãos de esqueleto e às paredes dos poros. Para se saber a origem dos cutãs é necessário distinguir algumas características como: natureza do material, nitidez dos limites, orientação, distribuição, grau de separação (contraste) em relação ao fundo matricial. (BREWER, 1964) 
Assim, RUELLAN \& DOSSO (1993) sintetisaram as interpretações possíveis sobre a origem das bandas onduladas, como sendo de dois tipos:

-de acumulação: devido a migração vertical e lateral de argila; -de degradação e lessivagem de partículas argilosas: as bandas são residuais do empobrecimento em argila de um horizonte argiloso. Esses autores ainda sintetisaram a definição das bandas onduladas como camadas de espessura milimétrica a centimétrica, mais ricas em argila, ferro ou matéria orgânica. Essas camadas, geralmente horizontais, são sempre onduladas, com ondulações mais ou menos acentuadas.

O horizonte B textural é um horizonte mineral que se caracteriza por um significativo aumento da fração argila em relação aos horizontes $A$ ou $E$ suprajacentes. Uma de suas feições indicadoras é a presença de películas de material coloidal (cerosidade) na superfície das unidades estruturais (torrões) ou dos poros. Outra feição comum desse tipo de horizonte diagnóstico, quando tem textura argilosa é a estrutura, geralmente em blocos ou mesmo prismática composta de blocos (OLIVEIRA et al, 1992).

ESWARAN \& SYS (1979) dão ênfase também, além da cerosidade, à presença de cutãs como características principais para a classificação destes horizontes como Bt e afirmam que os três processos envolvidos na formação do horizonte Bt são: dispersão, transporte e acumulação de argila, sendo que cada um deles requer condições específicas do solo. Segundo esses autores, a floculação e a dispersão são propriedades eletro-químicas do colóide e são influenciadas pelo $\mathrm{pH}$, concentração dos eletrólitos e a natureza do colóide. Para que haja o transporte é necessário que haja circulação hídrica. As observações indicam que os solos com condições úmidas e secas alternadas têm melhor desenvolvimento do horizonte $\mathrm{Bt}$, que aquelas que são constantemente secas ou úmidas, além da textura do material ser também importante. A acumulação pode se dar por dois mecanismos: deposição física ou floculação, ou pela associação desses processos. 
FEDOROFF \& ESWARAN (1985) apresentam três características que podem ser utilizadas para classificar um Bt no campo: presença de um horizonte eluvial acima do horizonte $\mathrm{Bt}$, estrutura em blocos e ausência de microagregação, característica dos latossolos. Ainda segundo esses autores, cujas idéias foram muito bem sintetisadas por COOPER (1996), a argila dos horizontes Bt pode se originar de: a) um material transportado e misturado no solo; b) um material intemperizado; c) um material iluviado fino misturado pela fauna do solo; d) um material herdado de um horizonte óxido; e) feições pedológicas na forma de cutãs de iluviação ou preenchimentos correspondendo à argiluviação presente; f) fragmentos de feições argilosas, provavelmente herdados do material de origem e formados quando o horizonte foi perturbado ou transportado e g) feições pedológicas perturbadas correspondentes a argiluviações passadas. Esses autores atentam para o fato de que muitas vezes os cutãs não são identificados no campo, mas aparecem nas lâminas delgadas, durante o estudo micromorfológico.

NETTLETON et al (1969) já afirmavam que os cutãs de iluviação são ausentes em horizontes com alto potencial de contração-expansão, mas micromorfologicamente aparecem como separações plásmicas em ilhas (insépica) e separações plásmicas em agrupamentos de ilhas (mossépica), enquanto nas separações plásmicas estriadas (massépica e omnissépica) eles não aparecem.

ESWARAN \& SYS (1979) explicam que a argila que se move em suspensão na água é absorvida pelas paredes dos torrões ou dos poros como um filtro retendo as plaquetas de argila, que são depositadas nestas superfícies. As plaquetas são paralelamente orientadas na superfície dos poros e paredes dos torrões, resultando oticamente em cutãs orientados. No caso das argilas serem depositadas por floculação, a orientação é ao acaso e muitas vezes a argila é incorporada ao fundo matricial, não formando cutãs.

No Brasil, alguns autores têm indicado a degradação das argilas como um importante processo pedogenético na formação de solos com Bt. (VIDAL 
TORRADO, 1994) Assim, CASTRO (1989) em estudo realizado em Marília conclui que os horizontes A e E são originários da degradação dos $B$ anteriores, acarretados por ampla eluviação e iluviação restrita e com sinais de desmantelamento, observado pelas figuras de iluviação ligadas à hidromorfia suspensa do topo do $\mathrm{Bt}$, inicialmente por dissolução e posterior transporte das argilas, deixando uma forte porosidade cavitária coalescente (CASTRO \& CURMI (1987) no topo dos Bt e na base das bandas onduladas. 


\section{PROCEDIMENTOS DE ESTUDO}

\subsection{Critérios de seleção da área específica}

O setor inicial de estudo compreendeu o trecho centro-sul do glacis, mais precisamente sua transição para a zona dissecada, no interflúvio dos Ribeirões do Meio-Samambaia. A escolha deste setor deveu-se ao fato do reconhecimento preliminar expedito (de campo) e fotointerpretação anterior (OLIVEIRA, 1992) terem revelado a presença de um sistema pedológico constituído por: Areias Quartzosas(AQ), Areias Quartzosas com bandas onduladas intermediárias para Podzólico Vermelho-Amarelo (AQ/PV), Podzólicos Vermelho-Amarelos (PV) e Litossolos (Li).

A área específica de estudo, ou seja, a vertente do Córrego do Retiro (Fazenda Retiro) foi escolhida por ser representativa do setor de transição do glacis para a zona dissecada tanto em termos de forma do relevo, como por apresentar, já no topo do interflúvio principal, perfis de Areias Quartzosas com inúmeras bandas onduladas no volume subsuperficial, bem contrastadas, acima de um volume profundo com características de Areia Quartzosa sem bandas, similares aos do topo do glacis preservado. (FOTO 1)

\subsection{Levantamento de campo: macromorfologia}

O levantamento de campo foi feito em duas etapas: a inicial, para a cartografia dos solos da vertente e a subsequente, para todos os detalhamentos necessários para melhorar a precisão de limites e transições laterais entre os solos presentes, bem como para coletas complementares ou sistemáticas de amostras. 


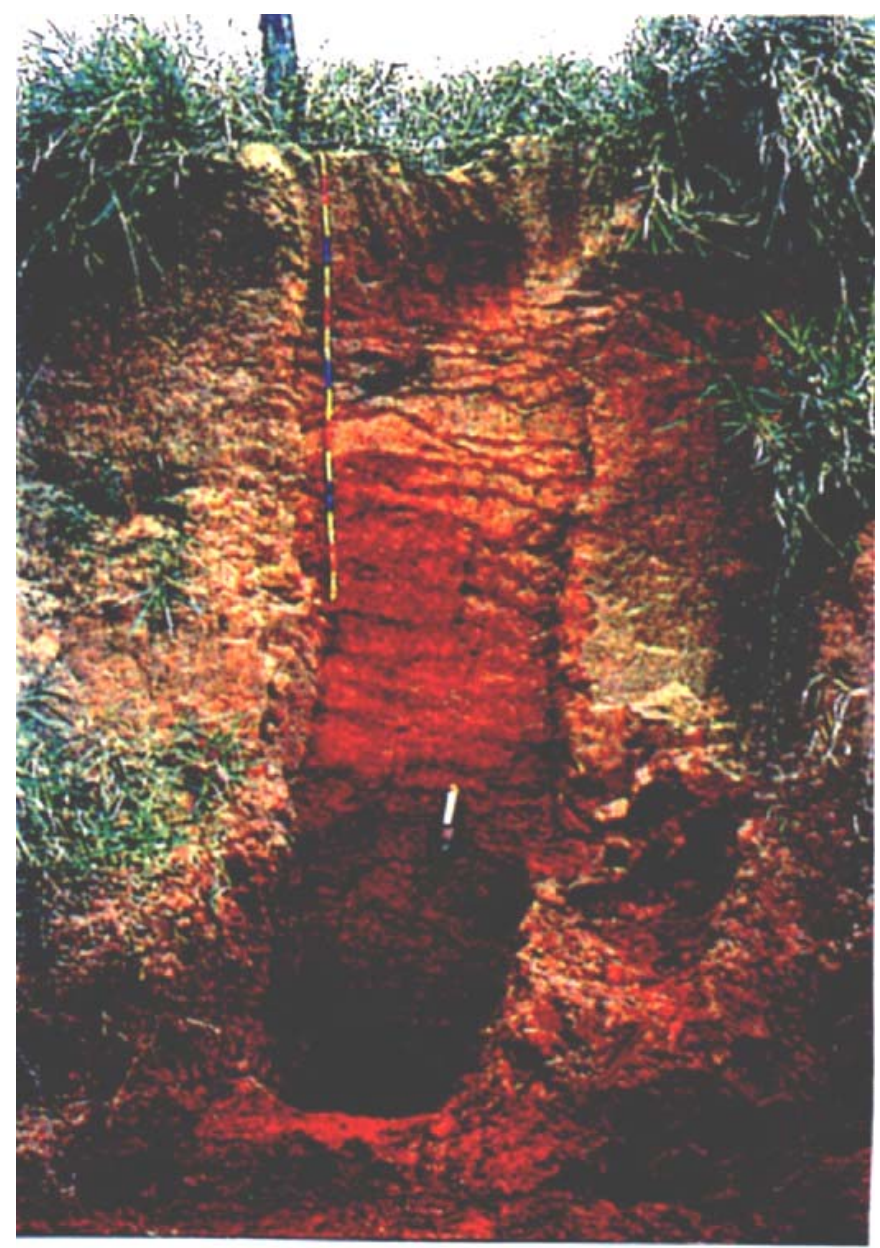

FOTO 1 - Perfil de Areia Quartzosa intermediária para Podzólico Vermelho Amarelo da transição glacis -zona dissecada. Nota-se que as bandas são mais coalescentes para a base do perfil. 
A etapa inicial foi desenvolvida durante um curso para treinamento em análise bi e tridimensional da cobertura pedológica ministrado por Ruellan, Boulet, Castro e Dias Ferreira, em 1993, conforme o já exposto.

O procedimento adotado nesta etapa foi o que segue:

a)Descrição morfológica dos perfis com bandas onduladas do barranco da estrada do interflúvio que marca o segmento montante da vertente estudada, adaptando-se os critérios gerais contidos em LEMOS e SANTOS (1982), no que se refere ao maior detalhe dado à descrição e desenho das organizações macroscópicas e em particular, dos diversos volumes observados nos perfis;

b)Sondagens a trado e abertura das trincheiras SPFR (ㅌão Pedro Fazenda Retiro) 14 e 8, imediatamente atrás do barranco da estrada para verificar se as bandas onduladas apareciam nas tradagens e também nas trincheiras;

c)Traçado de 4 topossequências dispostas do topo à base da vertente a partir dos pontos mais altos de montante, originalmente identificadas por números romanos (I-II; III-IV; V-VI; VII-VIII) representando os pares compostos dos segmentos montante e jusante de cada topossequência;

d)Realização de tradagens e do levantamento topográfico expedito com bússola, clinômetro e trena, ao longo dos eixos das topossequências e seqüências de amarração para a elaboração da base cartográfica;

e)Elaboração da base topográfica (FIGURA 5);

f)Realização de tradagens e aberturas de trincheiras (TR-1 e TR-2, próximas ao final do $\mathrm{Bt}$ ) no eixo da então sequência $\mathrm{V}-\mathrm{VI}$, central na vertente (ora denominada Topossequência Retiro I);

g)Comparação entre as amostras coletadas por tradagens ao longo das topossequências e das trincheiras com auxílio de pedocomparadores;

h)Tradagens ao longo dos demais eixos para amarrações laterais de distribuição dos horizontes, em especial do $\mathrm{Bt}$ e mapeamento das curvas de isodiferenciação (de aparecimento e de desaparecimento do Bt);

i)Construção do desenho das topossequências em papel milimetrado e estudo comparativo das distribuições encontradas; 


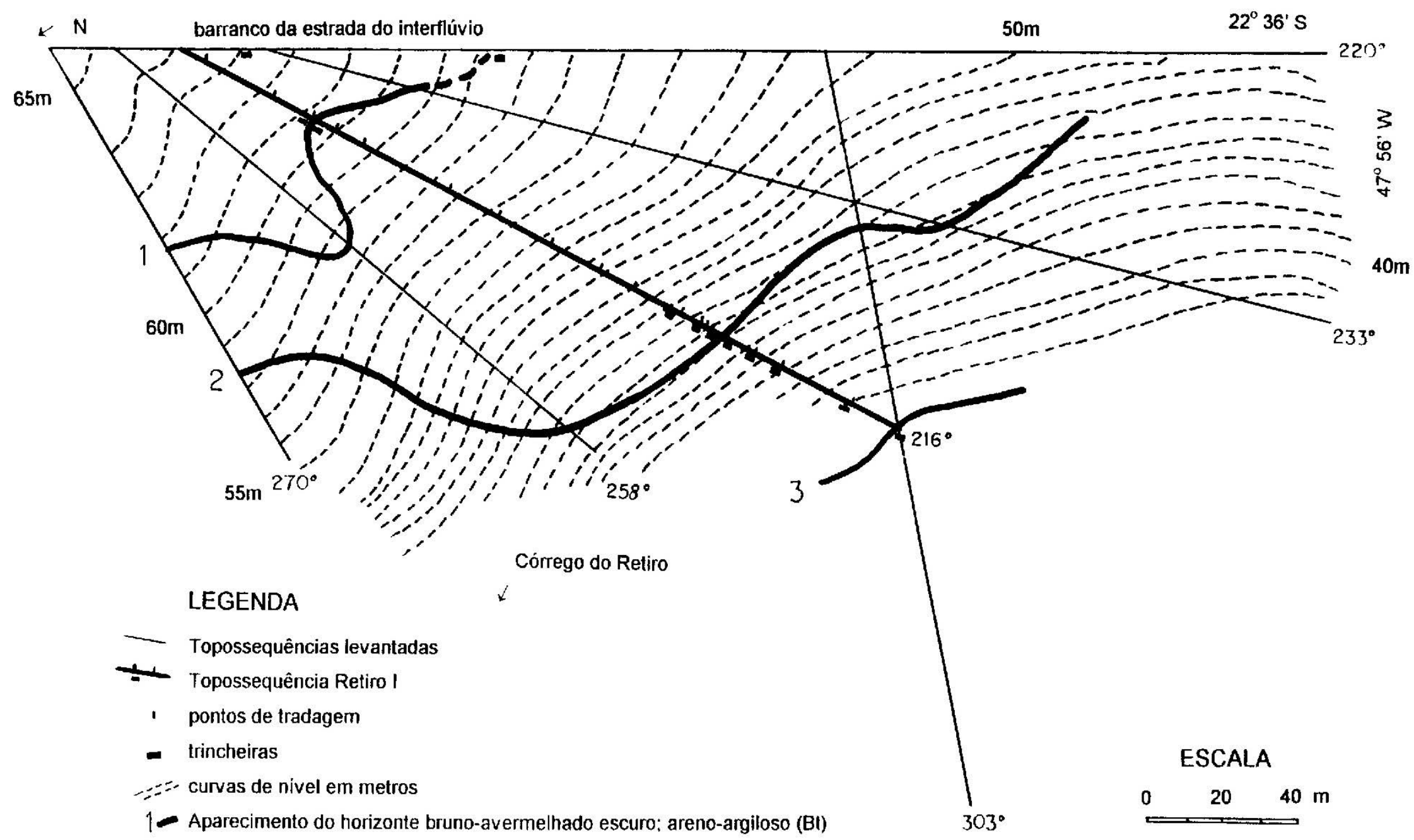

2- Desaparecimento da cobertura podzólica

3 - Aparecimento da alterita de justaposição com rede bruno-acinzentada clara englobando volumes amarelo-avermelhados com periferia branca

Org.: BOULET, R.; DIAS FERREIRA, R.P. \& OLIVEIRA, D. de, 1993-94. 
j)Escolha da topossequência representativa da vertente para estudo micromorfológico e analítico de rotina;

k)Coleta de amostras de trincheiras para micromorfologia e análises de laboratório (rotina);

k)Lançamento das curvas de isodiferenciação e dos eixos das topossequências com todos os pontos de observação por tradagem ou trincheira sobre a base cartográfica.

Os trabalhos de campo posteriores se deram para coleta sistemática ou complementar de amostras para:

a)Realização de análises granulométricas por tradagens sistemáticas profundas a intervalos de $10 \mathrm{~cm}$ até e inclusive o material basal similar à $A Q$ do topo da vertente, ou o assoalho do lençol mais à jusante) nos mesmos pontos de tradagens realizados na fase inicial de levantamento, com vistas à elaboração de curvas de isovalores sobretudo de argila ao longo da topossequência;

b)Abertura de novas trincheiras e coletas de amostras dos horizontes e transições para granulometria e micromorfologia, de montante à jusante: a TR10 e a TR 3, próximas ao início do Bt; a TR 5 e TR 6, próximas ao final do Bt; a TR7 e a TR 8, na zona de hidromorfia, à jusante do Bt e a TR 4 e a TR 9, na zona de ocorrência do horizonte ligado ao arenito alterado;

c)Detalhamento do segmento jusante da topossequência (denominado VI-100), onde aparece o horizonte de alteração do arenito, ligado ao ravinamento da vertente;

d)Estudo de uma trincheira de $3,5 \mathrm{~m}$ de comprimento para analisar o aparecimento do $\mathrm{Bt}$ e suas relações com as Areias Quartzosas com bandas onduladas (intermediárias para PV), a TR 11;

e)Busca da terceira curva de isodiferenciação, correspondente ao aparecimento do horizonte de alteração do arenito, a jusante da topossequência. 


\subsection{Micromorfologia}

Esta análise foi desenvolvida em duas etapas, a de preparação de amostras e a de observação e descrição das lâminas, conforme a seguir:

1-Impregnação de amostras indeformadas

Foi realizada no Instituto de Geociências, na Sala de Impregnação com a orientação do Prof. Dr. René Boulet, segundo procedimento de CHAUVEL resumido por CASTRO (1985), totalizando 61 amostras.

2- Polimento de amostras impregnadas

Corresponderam ao polimento de amostras reimpregnadas para tomada de fotos de amostras consideradas representativas das organizações visíveis sob lupa binocular, no Laboratório de Pedologia-FFLCH-USP, conforme o proposto por René Boulet, utilizando-se querosene e lixas d'água $n^{\text {os }} 100$ (grossa), 180 (média) e 600(fina).

3- Fabricação das lâminas delgadas

Foram fabricadas 58 lâminas no total, sendo que 25 lâminas médias, de tamanho $5 \times 7 \mathrm{~cm}$ foram fabricadas no Departamento de Planejamento Regional da UNESP-Rio Claro, em máquina politriz francesa de marca BROT.

As outras 33 lâminas foram fabricadas no Instituto de Geociências-USP de tamanho $2,5 \times 4,5 \mathrm{~cm}$.

4- Descrição Micromorfológica

Para a descrição micromorfológica utilizou-se a apostila compilada por CASTRO (1989), empregando-se a terminologia de STOOPS \& JONGERIUS (1975) para as estruturas de base (distribuição relativa entre plasma, esqueleto e poros) e BREWER (1964) para a análise do esqueleto e da porosidade, dando-se sempre especial atenção às transições verticais e laterais entre horizontes.

A descrição obedeceu a critérios gerais propostos por CASTRO (1989) como:

a)Ordenação das lâminas por perfil e na topossequência;

b)Observação inicial sob baixo aumento seguido de aumentos progressivamente maiores, sob luz natural (L.N.) e polarizada (L.P.), em 
especial para as estruturas plásmicas e as feições pedológicas, sobretudo cutânicas;

c)Seleção de campos representativos das organizações presentes com elaboração de croquis;

d)Construção de quadros-síntese e de desenhos para caracterizar a evolução lateral dos arranjos (estruturas);

e)Tomada de fotomicrografias;

f)Correlação das organizações observadas com aquelas de campo (macromorfológica dos perfis e da topossequência) e com os demais dados analíticos.

A quantificação dos componentes foi obtida por estimativa visual.

\subsection{Análises rotineiras e convencionais de laboratório}

As análises foram realizadas com o intuito de auxiliar a compreensão dos mecanismos físicos e químicos da topossequência estudada, tendo em vista melhor caracterizar as variações morfológicas verticais e laterais e correlacionálas com os prováveis processos formadores das estruturas pedológicas.

\section{Granulometria}

Correspondeu à preparação de 207 amostras no Laboratório de Pedologia-USP para o encaminhamento ao Laboratório da ORSTOM em Caiena, Guiana Francesa, conforme acordo estabelecido dentro do convênio CAPES $X$ COFECUB, já citado. As amostras foram preparadas conforme o exposto por MONIZ (1972) e o método utilizado para a realização da análise foi o da pipeta de Robinson para os finos (silte, argila) e tamisagem para a fração grosseira. A escala granulométrica adotada foi:

$<2 \mu, 2-20 \mu, 20-50 \mu$ (pipetagem) e 50-200 $\mu, 200-2000 \mu$ (peneiragem), respectivamente: argila, silte fino, silte grosso, areia fina, areia grossa. 
A coleta de amostras para granulometria foi realizada em todos os pontos de tradagem ao longo da topossequência Retiro I, de montante à jusante, para determinação da distribuição percentual das partículas do solo. (QUADRO 4ANEXO I)

Os resultados das análises permitiram:

1)Construção de gráficos verticais de valores simples e valores acumulados em profundidade (amostrados por tradagem) para os resultados da granulometria, correspondentes às frações presentes;

2)Elaboração das curvas de isovalores de argila e da relação textural areia fina/areia grossa.

\section{Análises Químicas}

As amostras utilizadas para as análises químicas somaram um total de 147 amostras. Estas foram separadas e pesadas no Laboratório de Pedologia-USP e encaminhadas à ESALQ-USP, onde sofreram as análises químicas convencionais conforme CAMARGO et al (1986). (QUADRO 5-ANEXO I)

Foram escolhidos perfis intercalados a partir do perfil da montante (V1, V4, V5a, V3b, VI 6, VI 7, VI 4, VI 11) por se considerar que seriam suficientes para uma amostragem das relações químicas na topossequência como um todo.

Foram realizadas as seguintes análises:

-pH em cloreto de cálcio: por determinação potenciométrica;

-matéria orgânica: por oxidação com bicarbonato de potássio;

-bases trocáveis: $\mathrm{Ca} 2+$ e $\mathrm{Mg} 2+$ trocáveis por espectrofotometria de absorção atômica e K+ trocável por fotometria de chama;

-acidez titulável e alumínio trocável: $\mathrm{AL3}+$ e $\mathrm{H}+$ trocáveis por titulação e $\mathrm{H}^{+}$ calculado por diferença.

Os resultados das análises permitiram:

1)Construção de gráficos de variação em profundidade para todos os resultados; 
2)Curvas de isovalores em classes de distribuição dos resultados de $S, T, V \%$ e Ki.

O fluxograma a seguir (FIGURA 6) ilustra o conjunto global de etapas, conforme o acima exposto e foi adaptado de CASTRO (1989). 
FIGURA 6 - Fluxograma das etapas da pesquisa (cf. CASTRO, 1989)

PROSPECÇÃO

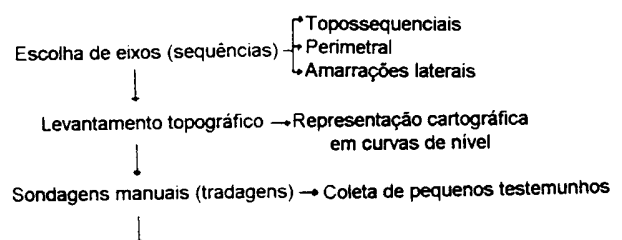

1

Locação e descrição de trincheiras em pontos-chave das sequèncias

Controle suplementar das
curvas para amarraçáo por - Identificaçăo das curvas $\rightarrow$ Lançamento dos pontos de interjecçäo das curvas nas sequèncias bidimensionais

tradagem com base em de isodiferenciação

volumes-guia

+dentificaçăo e caracterização dos volumes pedológicos e suas transiç̄es

Representação gráfica bidimensional das sequências

CARTOGRAFIA (sintese) $\rightarrow$ Representaçáo das sequéncias

Escolha de topossequência representativa da área cartografada

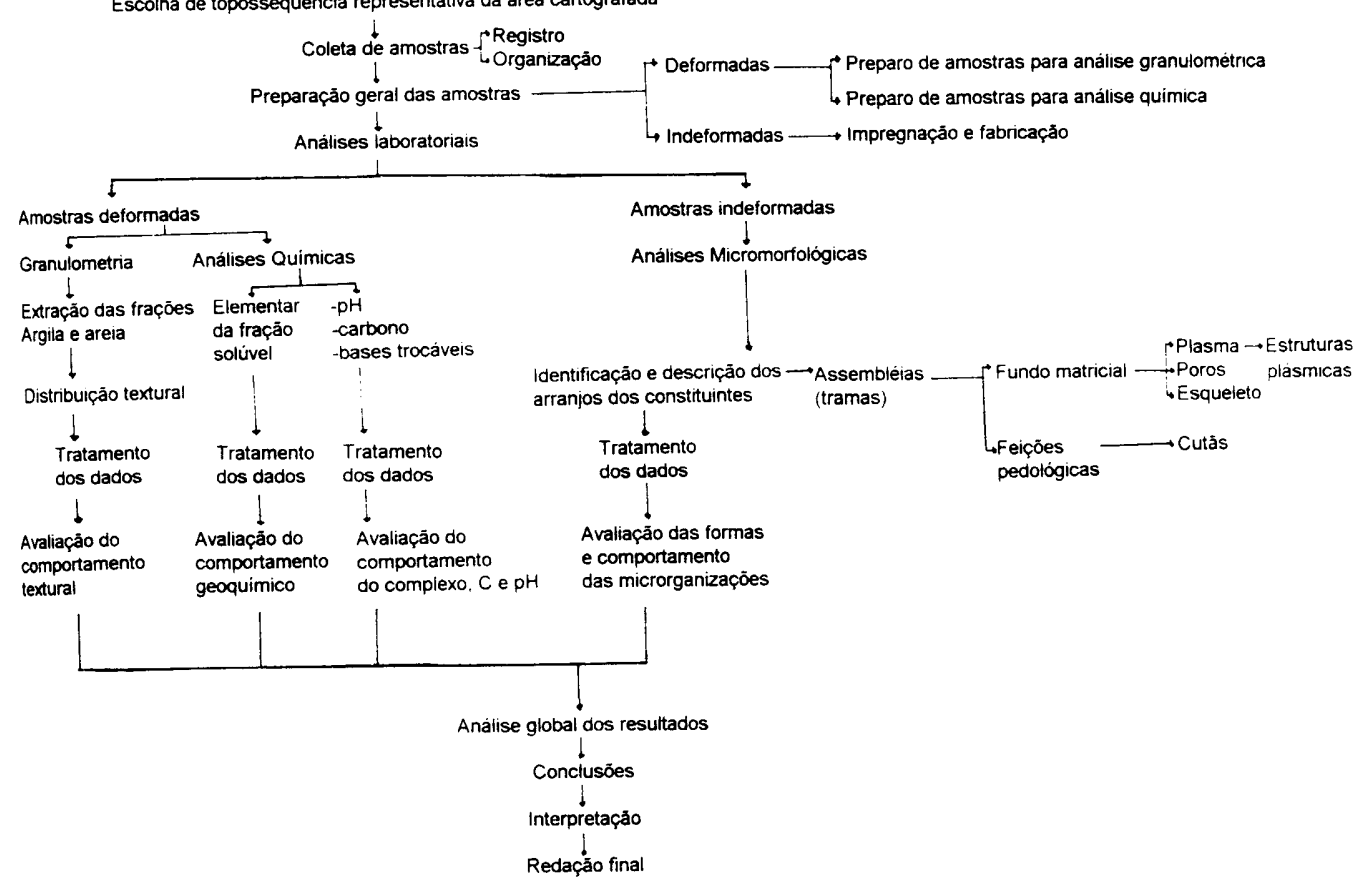




\section{RESULTADOS OBTIDOS}

\subsection{Macro e micromorfologia da Topossequência Retiro I}

A vertente onde se encontra o sistema pedológico estudado apresenta extensão total de $550 \mathrm{~m}$, altitude de 560 a $495 \mathrm{~m}$ e declividade da ordem de $14 \%$ do topo à média vertente e $20 \%$ daí em diante, até o sopé.

A topografia da vertente como um todo é convexa no topo e côncava a partir da ruptura de declive da média vertente, a partir da qual ocorre ravinamento e, para jusante, próximo ao Córrego do Retiro, termina por cornijas com afloramento do arenito.

À montante apresenta uma cobertura arenosa espessa (Areia Quartzosa), vermelha-amarela dominante com volumes de areia lavada na superfície e bandas onduladas na subsuperfície, que passa lateral e verticalmente para a média vertente a uma organização podzólica mais e mais definida. Para a baixa vertente passa aos Litossolos, onde foram observados os fenômenos de "piping" na base dos perfis junto à alterita.

A FOTO 2 apresenta uma visão geral da vertente.

A topossequência ora estudada - Retiro I - situa-se no eixo central dessa vertente (rever FIGURA 5); apresenta 224 m de extensão, direção NE-SO e corresponde apenas ao setor superior e médio da vertente, da qual foi excluida a parte do setor inferior, conforme o já exposto anteriormente.

A FIGURA 7 apresenta a topossequência Retiro I.

De forma geral, a topossequência apresenta a seguinte sucessão de horizontes:

O horizonte A (superficial) aparece em quase toda a extensão da vertente, com espessura de aproximadamente $20 \mathrm{~cm}$, variando ao longo da topossequência de 10 a $30 \mathrm{~cm}$; é arenoso com areia lavada. O horizonte E (subsuperficial) é vermelhoamarelo, também arenoso com areia lavada; sua espessura é de $80 \mathrm{~cm}$ no topo da vertente, diminuindo para jusante até o ponto VI 14, onde passa ao Eg, já arenoargiloso e com sinais de hidromorfia. 


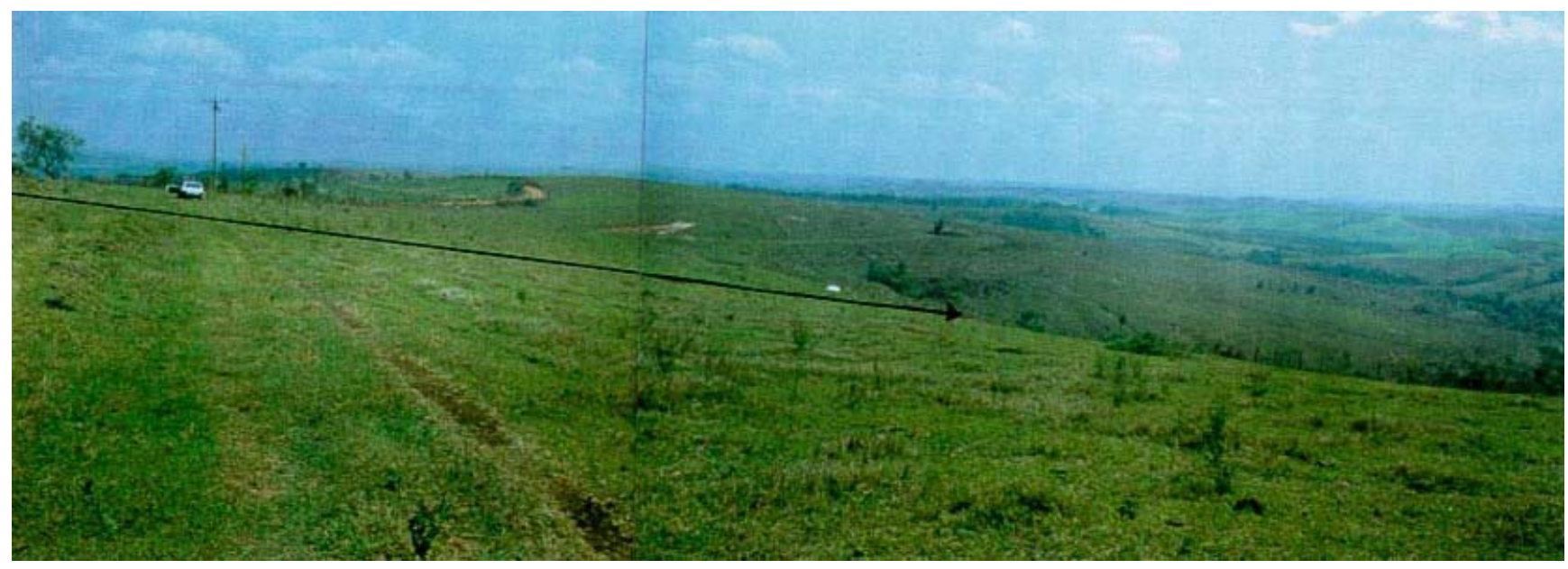

FOTO 2 - Visão geral da vertente.Tomada do Norte para o Sul da área (zona dissecada), apresentando em primeiro plano os segmento smédio e inferior da Topossequência Retiro I, que aparece demardada.

$\rightarrow$ Topossequência Retiro I 


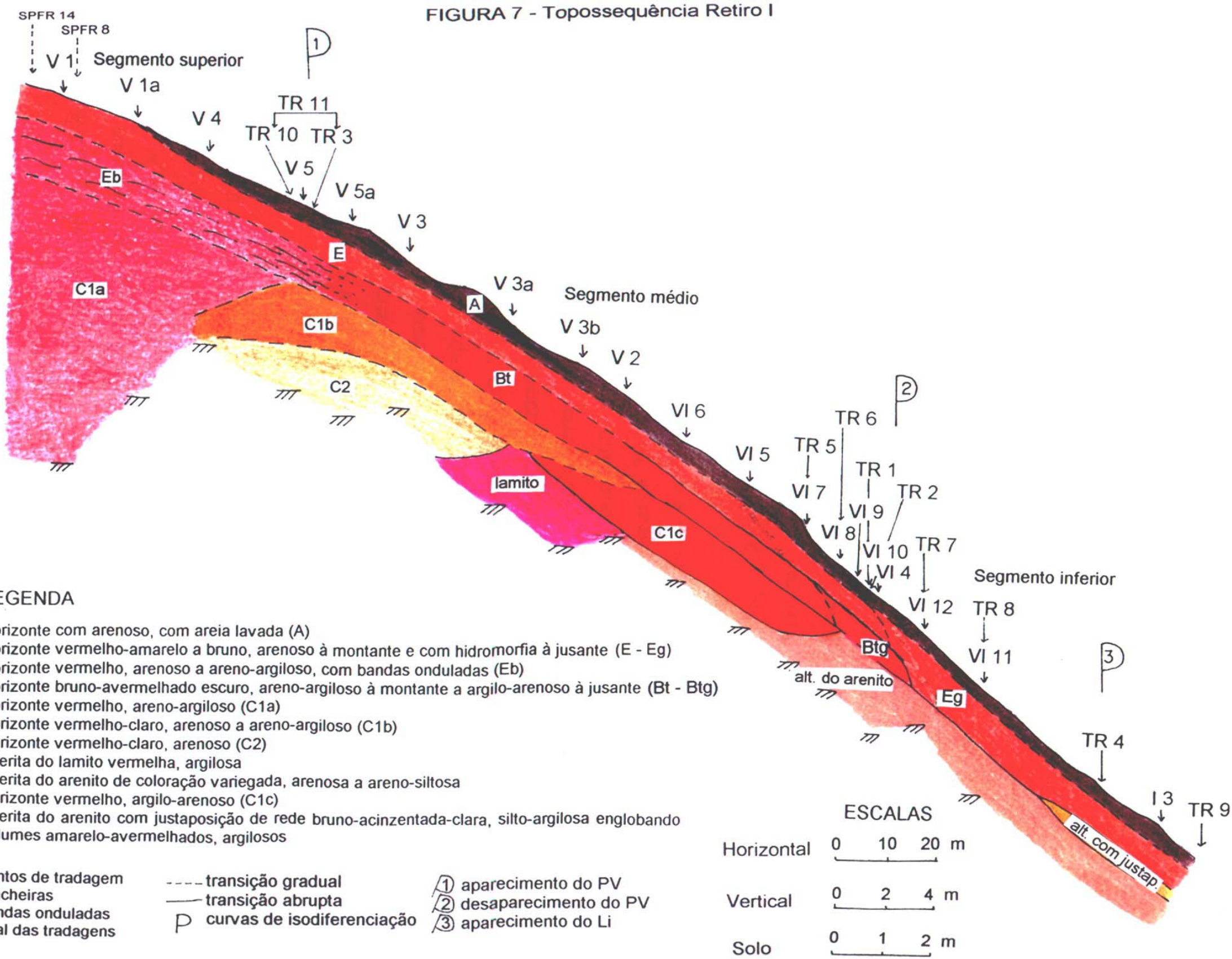


O horizonte $\mathrm{Eb}$ (bandas) aparece apenas no topo da vertente e corresponde ao horizonte vermelho com bandas (Areia Quartzosa do topo) com espessura de $1 \mathrm{~m}$ no ponto $\mathrm{V} 1$. Este passa progressivamente ao horizonte $\mathrm{Bt}$ arenoso a areno-argiloso na média vertente, com $60 \mathrm{~cm}$ de espessura aproximadamente, do ponto $\mathrm{V} 4$ até $\mathrm{VI} 7$, onde passa ao Btg, areno-argiloso a argilo-arenoso, com rede bruno-avermelhada, até o ponto VI 4, onde termina a cobertura podzólica. O horizonte $\mathrm{C} 1 \mathrm{a}$ é vermelho, areno-argiloso e encontra-se na base da $\mathrm{AQ}$ com bandas onduladas do topo; sua espessura não foi determinada e termina em cunha no ponto $\mathrm{V} 5$, a partir de onde aparece o horizonte $\mathrm{C} 1 \mathrm{~b}$, vermelho-claro e arenoso a areno-argiloso, com espessura de $1,2 \mathrm{~m}$, tornando-se mais estreito para jusante, terminando em cunha no ponto $\mathrm{V} 2$. No ponto $\mathrm{V} 3 \mathrm{a}$ aparece o horizonte $\mathrm{C} 1 \mathrm{c}$, que é argilo-arenoso, homogêneo, com espessura variando de 1,8 a 2,3m e apresenta seixos de quartzo e nódulos de manganês. Abaixo do horizonte $\mathrm{C} 1 \mathrm{~b}$ aparece o horizonte $\mathrm{C} 2$, vermelho-claro e mais arenoso que o $\mathrm{C} 1 \mathrm{~b}$, sem espessura determinada, terminando no ponto $\mathrm{V} 3 \mathrm{a}$, onde aparece $\mathrm{a}$ alterita do lamito, com forma lenticular e espessura, até o fim da tradagem, de $3 \mathrm{~m}$. A alterita do arenito corresponde ao arenito Pirambóia alterado, que é de cor variegada bruno-escura, bruno-avermelhada e amarelada, com volumes esbranquiçados e nódulos de argila.

A alterita com justaposição aparece apenas próximo ao ponto III-3 e corresponde a um horizonte bifásico, com uma rede bruno-acinzentada-clara englobando volumes amarelo-avermelhados com periferia branca e está ligado ao Litossolo da baixa vertente.

A seguir, a descrição macromorfológica da topossequência inicia-se pela descrição do perfil representativo do segmento superior e prossegue em direção ao de jusante pelas variações verticais e laterais observadas por tradagens e nos perfis expostos nas trincheiras situados ao longo do eixo topossequencial. Segue-se a apresentação dos resultados do estudo micromorfológico das 
amostras em lâminas delgadas, coletadas nas trincheiras. As descrições das trincheiras encontram-se no ANEXO II, ao final.

\section{Segmento superior:}

Corresponde ao trecho montante da Topossequência (rever FIGURA 7), onde predomina a Areia Quartzosa com bandas onduladas, cujas trincheiras representativas estão na FIGURA 8.

$\mathrm{Na}$ escala macroscópica, a Areia Quartzosa com bandas onduladas de montante é representativa do trecho entre os pontos $\mathrm{V} 1$ a $\vee 5$ e aparece nas trincheiras SPFR 14 E SPFR 8, embora um pouco deslocadas do eixo topossequencial. Apresenta a seguinte sucessão vertical de horizontes, nesse setor:

-o horizonte superficial arenoso (E): espesso $(0-45 \mathrm{~cm})$, de cor brunoavermelhada (5YR 4/4), não se destacando nitidamente um horizonte humífero superior mais escuro; textura muito arenosa no topo, com ligeiro aumento do teor de argila para a base; presença de areia lavada, sobretudo na parte mais superficial; estrutura muito fraca média poliédrica; porosidade tubular e intergranular forte.

-o horizonte subsuperficial arenoso com bandas onduladas (Eb): espesso (45$145 \mathrm{~cm}$ ), diminuindo progressivamente a $115 \mathrm{~cm}$ para jusante ( $V$ 5); apresenta-se vermelho $(2,5 Y R 4 / 6)$ e caracteriza-se pela presença de um empilhamento composto de numerosas bandas onduladas subhorizontais relativamente paralelas entre si, mais e mais espessas e coalescentes em profundidade, intercaladas por volumes arenosos denominados de interbandas, mais claros, embora progressivamente em profundidade sejam mais avermelhados, menos contrastados com as bandas e menos espessos. Estas bandas são pouco contrastadas quando o solo está úmido e fortemente contratadas quando seco (rever FOTO 1); caracterizam-se principalmente por uma resistência um pouco maior à faca, uma textura com pouco mais de argila (arenosa a areno-argilosa); uma porosidade menor e uma intensa atividade biológica; as bandas 
FIGURA 8 - Perfis de Areia Quartzosa com bandas onduladas intermediária para Podzólico Vermelho Amarelo do segmento superior da Topossequência Retiro I

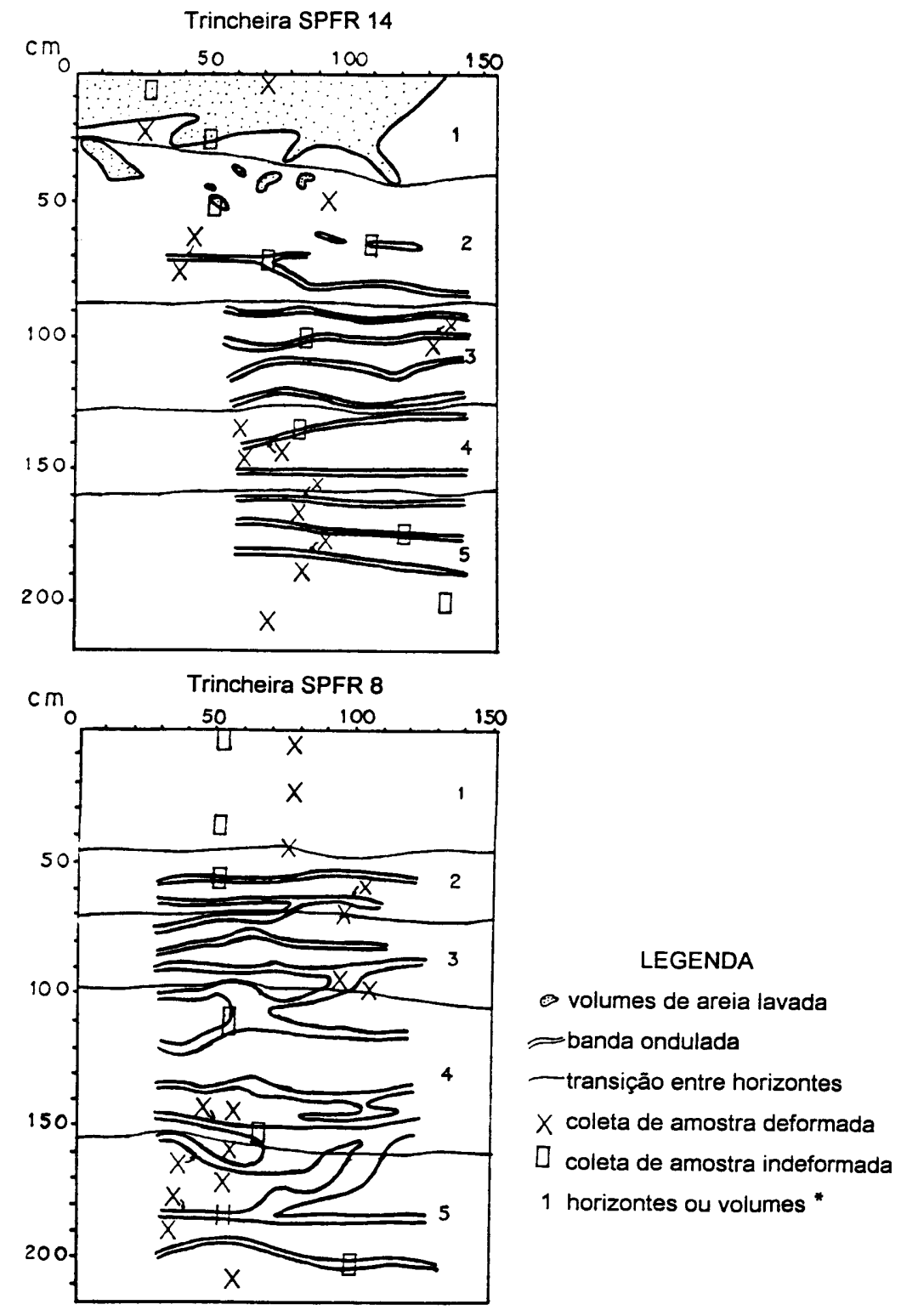

* os números correspondem à descrição dos horizontes por trincheira em ANEXO ॥ 
apresentam de 1 a $3 \mathrm{~cm}$ de espessura quando bem contrastadas, como na parte superior dos perfis e tornam-se mais espessas e anastomosadas rumo à base dos perfis. No material interbandas a cor é vermelho-escuro-acinzentado $(2,5 \mathrm{YR}$ 3/4) e com a lupa de bolso percebe-se a ocorrência de um retículo milimétrico vermelho vivo, contendo domínios de areia quase desprovida de fração argila (areia lavada); apresentam textura arenosa a areno-argilosa constante e volumes milimétricos isolados, similares às bandas (relíquias?); a estrutura passa progressivamente em profundidade de fraca poliédrica nas bandas para maciça com fratura cada vez mais plana nas interbandas.

-o horizonte profundo (C1a): muito espesso $(145-945 \mathrm{~cm}+)$; vermelho-escuro (2,5YR 4/4, 4/6 e 4/8); textura arenosa a areno-argilosa com areia lavada; estrutura maciça com fratura ligeiramente conchoidal, localmente com tendência à poliédrica; a porosidade é intergranular bem desenvolvida com alguns poros tubulares que contêm areia lavada.

A FIGURA 8 a seguir apresenta o desenho das trincheiras desse segmento.

Em síntese, o perfil representativo do segmento superior apresenta um horizonte superficial arenoso (E) com areia lavada sobre um horizonte com bandas onduladas subhorizontais centimétricas (Eb), areno-argilosas intercaladas por um material arenoso a areno-argiloso (interbandas), sendo mais espessas para a base do perfil até passar a um horizonte também arenoso a areno-argiloso $(\mathrm{C} 1 \mathrm{a})$, similar ao material interbandas mais profundo, com estrutura maciça. Fora das bandas o material é muito poroso e permeável, o que confirma a presença de areia lavada nos poros tubulares. As bandas são responsáveis pela diminuição da drenagem vertical por serem menos permeáveis que o material interbandas.

$\mathrm{Na}$ escala microscópica seus horizontes apresentam as seguintes características: o horizonte subsuperficial $(\mathrm{E})$ na TR 3 apresenta fundo matricial 
pobre em plasma com cerca de $5 \%$, além de cerca de $30 \%$ de poros e $60 \%$ de esqueleto.

Há predomínio de esqueleto ligado por pontes de plasma (estrutura gefúrica) que atingem cerca de $65 \%$ da lâmina e que formam um reticulado geométrico em cujo interior aparecem grãos limpos (estrutura mônica), que correspondem a cerca de $30 \%$ da lâmina, visíveis na FOTOMICROGRAFIA 1 1; há também pequenos agregados com grãos do esqueleto cimentados por argila (estrutura porfírica) de aproximadamente $1 \mathrm{~mm}$ de diâmetro com esqueleto mais fino em seu interior (5\%), esparsos no fundo matricial da lâmina.

O plasma é vermelho-amarelo sob luz natural e opaco sob luz polarizada, provavelmente pela presença da matéria orgânica e do ferro.

A porosidade mais importante é a de empilhamento simples dos grãos (80\%), seguida pela de cavidades (20\%). As cavidades são do tipo ortoporos, isto é, suas paredes são formadas pelo arranjo natural do plasma e esqueleto, apresentam formas irregulares no topo do horizonte e arredondadas na base, variam de $0,250 \mathrm{~mm}$ a $1,0 \mathrm{~mm}$ (macroporos muito finos) e são moderadamente comunicantes entre si nas duas dimensões da lâmina, mas são provavelmente comunicantes nas três dimensões.

O esqueleto é constituido basicamente de grãos de quartzo fino $(0,25$ a 0,125mm), com cerca de $98 \%$ de quartzo e de $2 \%$ de manganês e/ou carvões. Os grãos são subarredondados, lisos e com distribuição aleatória.

Há ainda a presença de poucos pedotúbulos tubulares simples do tipo granotúbulo com $1,6 \mathrm{~mm}$ de diâmetro em média, com densidade solta contínua em seu interior, individualização discreta (com limite bem nítido em relação ao fundo matricial); o agente de escavação pode ter sido minhoca ou raízes (não diferenciada na lâmina), a composição do preenchimento é de material proveniente do mesmo horizonte (ortotúbulo).

\footnotetext{
${ }^{1}$ A PRANCHA 1 apresenta as FOTOMICROGRAFIAS 1 a 7 , representativas do segmento superior da Topossequência Retiro I.
} 


\section{LEGENDA}

\section{PRANCHA 1:}

FOTOMICROGRAFIA 1 - L.N. 30X. Aspecto geral do horizonte E da TR 3 com predomínio de esqueleto ligado por pontes de plasma (estrutura gefúrica) formando um reticulado com grãos limpos em sel interior (estrutura mônica). FOTOMICROGRAFIA 2 - L.N. 30X. Aspecto geral do material interbandas do horizonte Eb do perfil SPFR 8 , onde predominam grãos de quartzo cimentados por plasma (estrutura porfírica) e que formam um reticulado com esqueleto ligado por pontes de plasma (estrutura gefúrica) em seu interior.

FOTOMICROGRAFIAS 3 a e b - L.N. e L.P. 80X. Topo de banda ondulada do horizonte $\mathrm{E}$ com bandas onduladas do perfil SPFR 8 com ferriargiläs iluviais de cavidades, com zonação posterior ao depósito devido a más condições de drenagem no interior de estrutura porfírica. Note-se a ferruginização (hidromorfia) e microfissuração posteriores às suas formaçōes.

FOTOMICROGRAFIAS 4 a e b - L.N. e L.P. 80X. Cutãs de iluviação da base da banda ondulada do horizonte Eb do perfil SPFR 8 . Note-se que a passagem é nítida da estrutura com esqueleto cimentado por plasma (estrutura porfírica) da banda para grãos ligados por pontes de plasma (estrutura gefúrica) do material interbandas; note-se ainda a fissuração dos cutãs e a quase ausência de zonações posteriores ao depósito.

FOTOMICROGRAFIA 5 - L.P. 125X. Cutãs de iluviação do interior da banda ondulada do horizonte Eb do perfil SPFR 8. Note-se a microlaminação dos cutãs de iluviação orientada em várias direções e algumas microfissuras posteriores ao depósito do plasma.

FOTOMICROGRAFIA 6 - L.N. 80X. Detalhe de um cutã de iluviação do limite inferior da banda do horizonte Eb do perfil SPFR 8, fissurado e se quebrando em pequenos fragmentos (pápulas) incorporadas ao fundo matricial porfírico. FOTOMICROGRAFIA 7 - L.P. 125X. Aspecto geral do horizonte C1a do perfil SPFR 14 com esqueleto ligado por pontes de plasma (estrutura gefúrica), forte porosidade de empilhamento e cavitária intercomunicante e plasma opaco. 
PRANCHA 1-Micromorfologia do segmento superior da Topossequência Retiro I

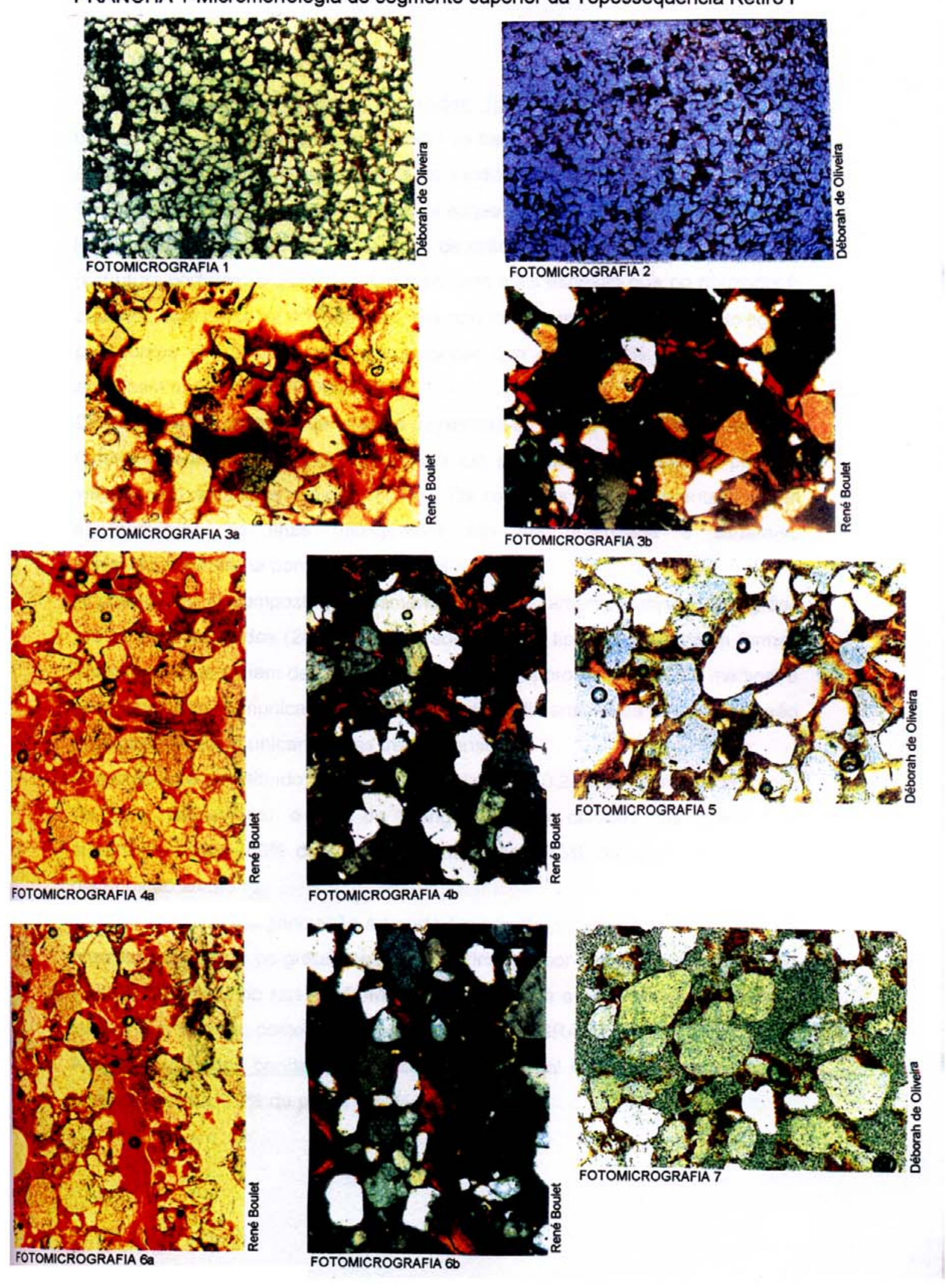


-o horizonte $\mathrm{E}$ com bandas onduladas (Eb) apresenta dois tipos de organização, uma externa e outra interna às bandas onduladas.

A organização interbandas apresenta um fundo matricial constituído de cerca de $15 \%$ de plasma, $30 \%$ de poros e $55 \%$ de esqueleto.

Predomina uma rede (reticulado) onde os grãos estão cimentados por plasma (estrutura porfírica) e que forma um reticulado mais espesso que no horizonte $\mathrm{E}$ superior, com cerca de $40 \%$ do total, em cujo interior apresenta esqueleto ligado por pontes de plasma (estrutura gefúrica) que atinge $60 \%$ do total e que aparecem na FOTOMICROGRAFIA 2.

Cerca de $85 \%$ do total de plasma apresenta-se bruno-avermelhado sob luz natural, predominantemente opaco sob luz polarizada e apresenta pápulas visíveis sob aumentos maiores (125x). Os restantes $15 \%$ apresentam-se em agrupamentos de ilhas (mossépico) sob luz polarizada e situam-se preferencialmente na porosidade de empilhamento.

A porosidade é composta basicamente de empilhamento simples dos grãos $(80 \%)$ e de cavidades $(20 \%)$. As cavidades são do tipo ortoporos, com formas irregulares, que variam de $0,5 \mathrm{~mm}$ a $2,0 \mathrm{~mm}$ (macroporos muito finos a médios) e são fracamente comunicantes entre si nas duas dimensões da lâmina, mas são provavelmente comunicantes nas três dimensões.

O esqueleto é constituído de grãos de quartzo fino $(0,25$ a $0,125 \mathrm{~mm})$, com cerca de $98 \%$ de quartzo e $2 \%$ de manganês e/ou carvões, os grãos são subarredondados ( $85 \%$ do total) a arredondados ( $15 \%$ do total), lisos e com distribuição aleatória.

A passagem desta organização à banda é marcada por um grande aumento de plasma cimentando os grãos (estrutura porfírica) e por cutãs de poros tanto no limite superior, como nas FOTOMICROGRAFIAS 3a e 3b e também no limite inferior das bandas, como o visto nas FOTOMICROGRAFIAS 4a e 4b.

A organização das bandas apresenta fundo matricial constituído por cerca de $35 \%$ de plasma, $10 \%$ de poros e $55 \%$ de esqueleto. 
Apresenta grãos de quartzo envolvidos numa matriz argilosa (estrutura porfírica) predominante e bem mais fechada do que na organização externa às bandas.

O plasma apresenta-se em dois tipos, um não cutânico (15\% do total) e um cutânico de poros e grãos predominante ( $85 \%$ do total). Ambos são brunoavermelhados, mas o plasma não cutânico apresenta separações em agrupamentos de ilhas (mossépico) que lembram pápulas fortemente integradas ao fundo matricial.

A porosidade é constituída basicamente de empilhamento simples dos grãos $(80 \%)$ e de cavidades (20\%). As cavidades são do tipo metaporos (com as paredes submetidas à pressões), apresentam formas irregulares, variam de $0,5 \mathrm{~mm}$ a $1,0 \mathrm{~mm}$ (macroporos muito finos) e são fracamente comunicantes entre si.

O esqueleto é semelhante ao externo às bandas.

Os cutãs de poro do topo das bandas são do tipo crescente (de fundo de poro), apresentam contraste forte, limite nítido em relação ao fundo matricial, distribuição laminada (por segregação do ferro), orientação forte, padrão estriado. Os cutãs de grãos são englobados ao fundo matricial, interligando grãos, com distribuição laminada e padrão estriado. Os cutãs do interior das bandas parecem ter sofrido estágios diferentes de acumulação, pois são crescentes, microlaminados, com contraste forte, limite nítido em relação ao fundo matricial e padrão estriado, mas assemelham-se a um empilhamento de vários cutãs interligados e orientados em direções diferentes, como os da FOTOMICROGRAFIA 5. Todas essas características se referem à cutãs de iluviação.

Para a base das bandas os cutãs laminados apresentam uma porosidade fissural geradora de pápulas ligadas aos cutãs relativamente preservados e que vão sendo incorporados ao fundo matricial porfírico, como o cutã que aparece nas FOTOMICROGRAFIAS $6 a$ e $6 \mathrm{~b}$.

-o horizonte de profundidade (C1a) apresenta cerca de $15 \%$ de plasma, $35 \%$ de poros e $50 \%$ de esqueleto. 
Os grãos estão ligados por pontes de plasma não cutânico (estrutura gefúrica) predominante, com cerca de $90 \%$ e também pequenos agregados de aproximadamente $0,6 \mathrm{~mm}$ que possuem grãos mais finos (silte) em seu interior envolvidos por plasma (estrutura porfírica) que alcançam cerca de $10 \%$ da lâmina.

O plasma é vermelho sob luz natural e sob luz polarizada é opaco e não cutânico, como é possível notar na FOTOMICROGRAFIA 7.

A porosidade predominante é a de empilhamento simples dos grãos (95\%), com contribuição de poucas cavidades $(5 \%)$, que variam de $0,5 \mathrm{~mm}$ a $2,0 \mathrm{~mm}$ (macroporos muito finos a grosseiros, predominando os muito finos), são do tipo ortoporos, arredondados e fracamente comunicantes entre si.

O esqueleto é constituído de grãos de quartzo fino $(0,25$ a $0,125 \mathrm{~mm})$, com $97 \%$ de quartzo e $3 \%$ de manganês e/ou carvões. Os grãos são subarredondados, lisos e com distribuição aleatória.

Em síntese, o segmento superior mostra um horizonte $\mathrm{E}$ pobre em plasma (cerca de $5 \%$ ), com predomínio de esqueleto ligado por pontes de plasma (estrutura gefúrica), que forma um reticulado com grãos sem plasma no interior dos retículos (estrutura mônica). A porosidade de empilhamento simples dos grãos é a mais importante, sendo que esses grãos são subarredondados e lisos em todo o perfil. O horizonte subsuperficial Eb (bandas onduladas) apresenta cerca de $15 \%$ de plasma, com uma organização onde os grãos estão cimentados por plasma (estrutura porfírica), formando também um reticulado que apresenta pápulas que podem corresponder a restos de bandas em cujo interior há esqueleto ligado por pontes de plasma (estrutura gefúrica); há presença de cavidades. As bandas onduladas apresentam cerca de $35 \%$ de plasma, com grãos de quartzo envolvidos numa matriz argilosa (estrutura porfírica), com muitos cutãs de poros e de grãos associados a iluviação; há presença de cavidades. O horizonte de profundidade ( $\mathrm{C} 1 \mathrm{a}$ ) apresenta cerca de $15 \%$ de plasma e esqueleto ligado por pontes de plasma (estrutura gefúrica); a 
porosidade mais importante é a de empilhamento simples dos grãos e há poucas cavidades.

A transição para o segmento médio se faz pela passagem do horizonte Eb (bandas onduladas) para o horizonte $\mathrm{Bt}$ lateral e progressivamente. Neste trecho, as bandas onduladas do $\mathrm{Eb}$ aparecem associadas ao $\mathrm{Bt}$, tanto na sua superfície e base, como no interior deste horizonte. A partir daí, o horizonte Bt torna-se mais desenvolvido e estruturado no rumo jusante, caracterizando um solo Podzólico.

A FIGURA 9 mostra as trincheiras TR 10, TR 11 e TR 3, representativas da passagem da Areia Quartzosa com bandas onduladas do segmento superior para o Podzólico do segmento médio. Tanto na TR10, como na TR3, as bandas pouco nítidas aparecem dentro do horizonte Bt. A TR11, que apresenta um detalhamento maior em relação às outras duas, mostra que o Bt aparece para jusante entre as bandas de superfície da Areia Quartzosa, tornando-se cada vez mais nítido e mais espesso ao longo dessa trincheira. As bandas tornam-se cada vez menos nítidas dentro do $\mathrm{Bt}$, que se desenvolve para jusante. Ainda não foi possível realizar o estudo micromorfológico das amostras da TR 11, mas apenas da TR 10 e TR 3, que representam respectivamente, a parte montante e a jusante da TR 11.

\section{Segmento médio:}

Neste segmento ocorre o Podzólico Vermelho-Amarelo. $\mathrm{Na}$ escala macroscópica ele se caracteriza por apresentar 4 horizontes sobre 0 arenito alterado, entre os pontos V 5 e VI 4. As trincheiras TR 10, TR 11, e TR3 são representativas da passagem do segmento superior para o médio (rever FIGURA 9) e as trincheiras representativas do segmento médio são: TR 5, TR 6, TR 1 e TR 2, representadas na FIGURA 10. As trincheiras TR 6 e TR 2 não 
FIGURA 9 - Perfis da passagem lateral das bandas onduladas ao Bt da Areia Quartzosa com bandas onduladas para Podzólico Vermelho Amarelo do segmento superior da Topossequência Retiro I

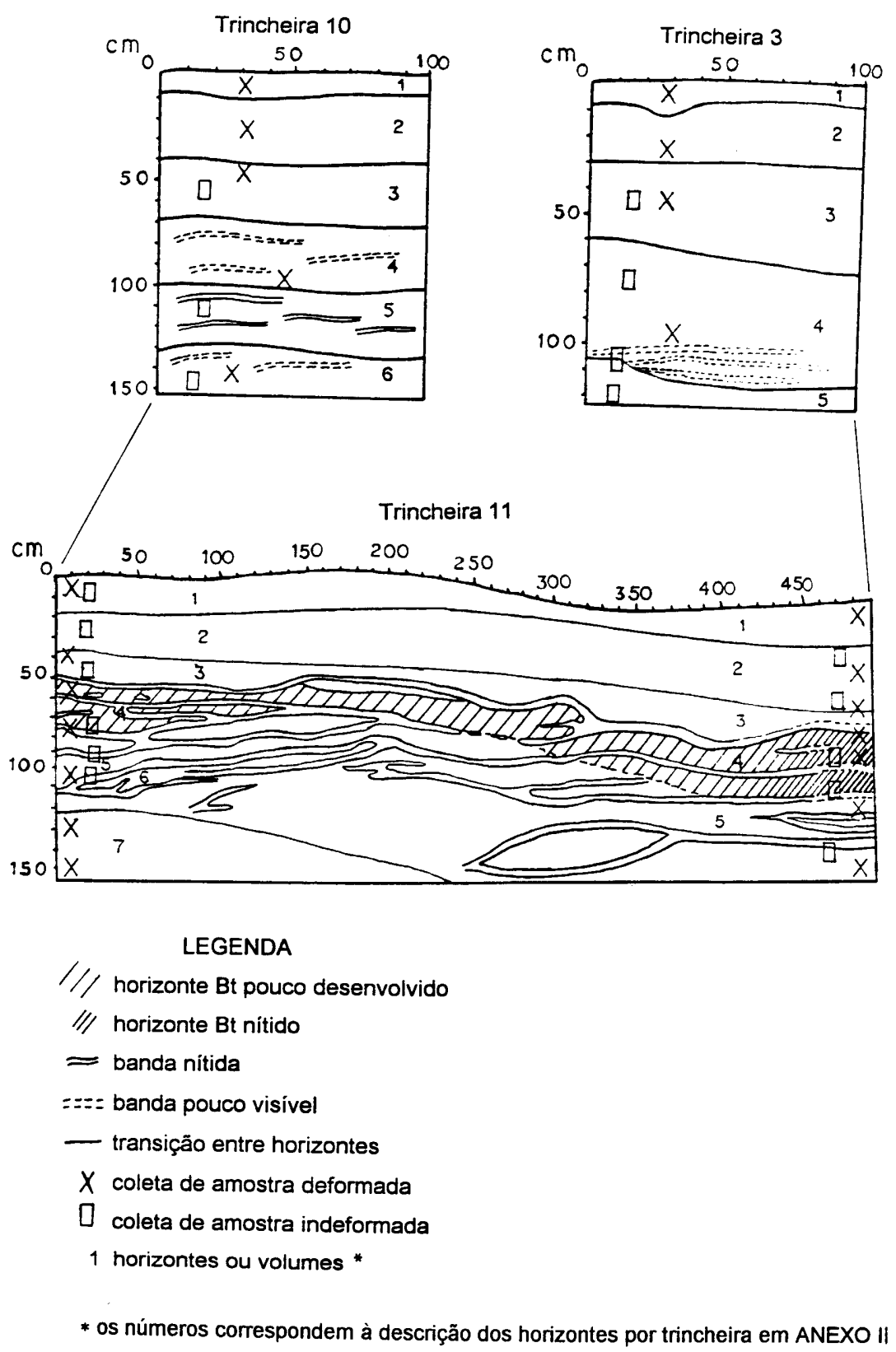


FIGURA 10 - Perfis do Podzólico Vermelho Amarelo do segmento médio da Topossequência Retiro I
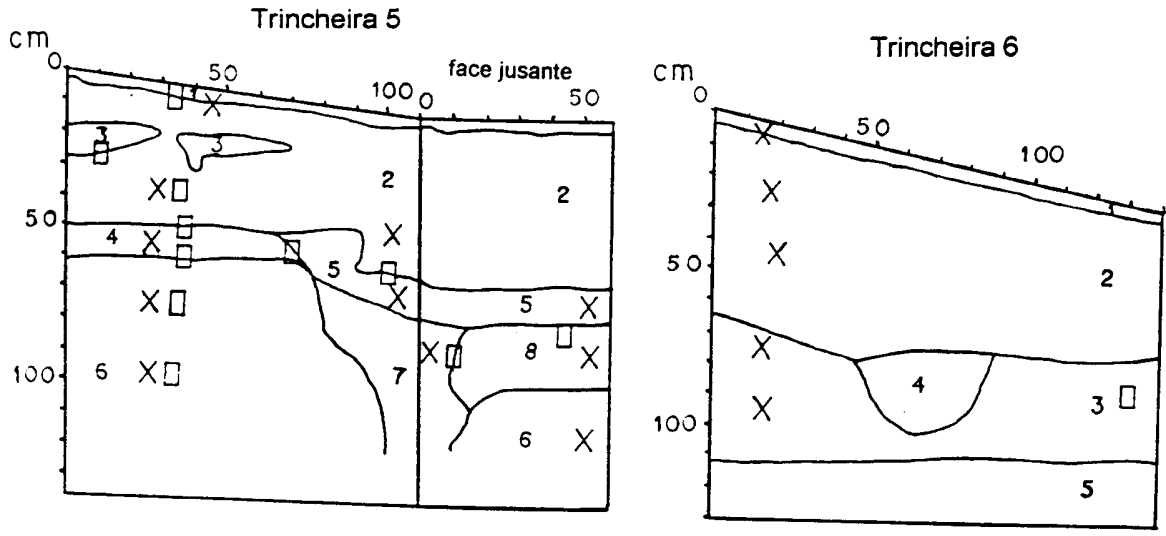

Trincheira 1

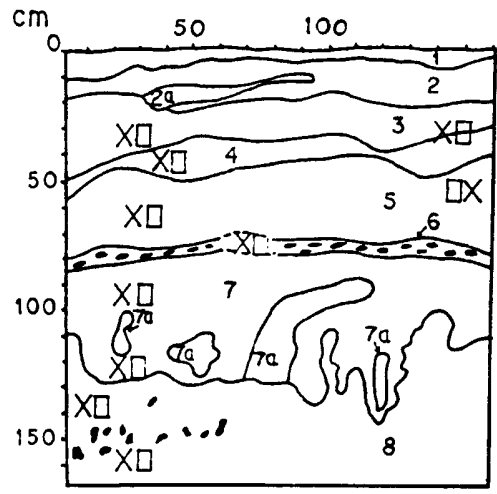

Trincheira 2

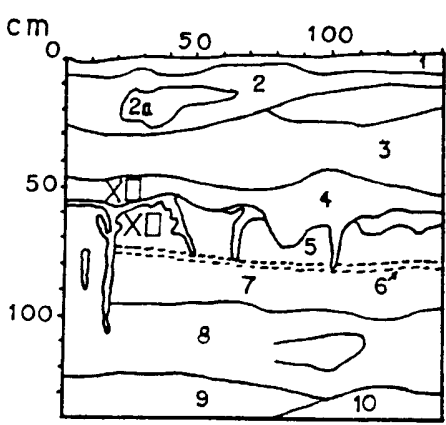

\section{LEGENDA}

- litorrelíquias vermelhas do arenito

linha de seixos continua

..:- linha de seixos pouco continua

- transição entre horizontes

$X$ coleta de amostra deformada

C coleta de amostra indeformada

1 horizontes ou volumes *

* os números correspondem à descrição dos horizontes por trincheira em ANEXO If 
foram analisadas por serem muito semelhantes às TR 5 e TR 1, respectivamente.

-o horizonte superficial (A): 0-10/30cm; bruno (7,5YR 4,5/3). A partir da TR11 aparecem volumes difusos centimétricos vermelho-amarelados (5YR 5/6) e a partir da TR-6 a cor muda para bruno-amarelado-escuro a bruno (10YR 4/4, 4/3); textura arenosa; estrutura fraca grande granular.

-o horizonte subsuperficial (E): 10/30-50/70cm; inicia-se com textura arenosa e passa a arenosa a areno-argilosa para jusante a partir do ponto V3. A partir do ponto VI 6 aparecem nódulos ou relíquias do arenito no seio da massa arenosa, pequenos volumes milimétricos de areia lavada e presença de manganês. Um pouco à jusante do ponto VI 5 , torna-se bruno (7,5YR 5/3) e cada vez mais úmido para jusante, onde é visível a presença de pontuações vermelhas formando uma rede bruno-acinzentada e bruno-avermelhada ligada à hidromorfia.

-o horizonte (Bt): 50/70-75/95cm. Aparece pela coalescência e espessamento progressivo, acima e abaixo dele, de bandas onduladas na base do perfil. As tricheiras TR 10, TR 3 e TR 11 são representativas desse aparecimento (rever FIGURA 9). Na TR 10, as bandas onduladas já aparecem no topo, base e dentro do $\mathrm{Bt}$, porém ligeiramente mais escuras que este e de cor vermelhoescuro (2,5YR 3/6) e textura arenosa a areno-argilosa. Na TR-11 à montante, este horizonte é bruno-avermelhado (5YR 3,5/4) a vermelho-escuro em profundidade (2,5YR 4/6); areno-argiloso; estrutura maciça com fratura conchoidal e mais resistente à faca que os demais horizontes do perfil; a porosidade é tubular e começa a aparecer por entre as bandas mais superficiais. Estas bandas são mais compactas, bruno-avermelhadas (5YR 3,5/4), porém mais escuras que o $\mathrm{Bt}$ e apresentam textura arenosa a arenoargilosa. Para jusante da TR 11, as bandas incluídas no Bt tornam-se pouco visíveis, conservando somente uma resistência ligeiramente maior à faca que o material do Bt que as separa. As bandas neste trecho são vermelho-escuras (2,5YR 4/6), têm textura arenosa a areno-argilosa, estrutura fraca média 
poliédrica e porosidade intergranular e tubular bem desenvolvidas. O horizonte Bt neste trecho torna-se bruno-avermelhado escuro (5YR 3/4) a vermelhoescuro (2,5YR 4/6); a textura continua areno-argilosa e também a estrutura continua maciça com fratura ligeiramente conchoidal. $\mathrm{Na}$ TR 3 as bandas aparecem na base do Bt e são contínuas, paralelas na base e pouco contrastadas com o $\mathrm{Bt}$, que é vermelho-escuro $(2,5 \mathrm{YR}, 4,6)$ e areno-argiloso. $\mathrm{Na}$ TR 5, mais à jusante, a textura do Bt passa a argilo-arenosa, onde foram observados revestimentos argilosos bem nítidos nas paredes dos agregados (cerosidade); a estrutura passa a forte grande poliédrica e a porosidade continua tubular (rever FIGURA 10). Aparecem aí ainda nódulos de manganês milimétricos e volumes bruno-acinzentados e bruno-avermelhados com fragmentos de quartzo milimétricos. Na TR 1 (Btg) há sinais de hidromorfia e manchas bruno-amareladas contrastadas com o horizonte $\mathrm{E}$ superior.

-o horizonte C1b: 75/95-195/215cm; vermelho-escuro $(2,5 Y R \quad 4 / 6,4 / 8)$; textura arenosa a areno-argilosa. Aparecem ainda volumes milimétricos de areia lavada e volumes mais vermelhos (bandas residuais?). No ponto $\mathrm{V} 3$ aparecem pequenos volumes de carvão (milimétricos a centimétricos). No ponto $\vee 3 \mathrm{~b} a$ textura passa a argilosa a areno-argilosa, dando lugar ao horizonte C1c: 100$190 \mathrm{~cm}$, que é mais homogêneo, bruno-escuro (2,5YR 4/8), argilo-arenoso, com alguns seixos de quartzo subarredondados centimétricos, assim como nódulos ferruginosos e de manganês esparsos (milimétricos). Entre os pontos V 2 e VI 6 o horizonte se torna mais espesso $(1 \mathrm{~m})$. No ponto VI 6 os nódulos de manganês aparecem no topo do horizonte e os seixos de quartzo na base. A partir da TR-5 sua cor muda para vermelho-amarelado (5YR 5/6, 5/8), diminuindo progressivamente a espessura até seu desaparecimento no ponto VI 4.

-o horizonte C2: 195/215cm+; horizonte de profundidade que tem seu início no ponto V5; é vermelho-escuro (2,5YR 4,5/8); com textura areno-argilosa e volumes milimétricos de areia lavada. No ponto V3a este horizonte desaparece em bisel em contato com o horizonte $\mathrm{C} 1 \mathrm{c}$ e com a alterita do lamito. 
-a alterita do lamito: $215 \mathrm{~cm}+$; aparece em forma de lente entre os pontos $\mathrm{V}$ 3a e V 2. Na base é vermelho-escuro a vermelho $(10 \mathrm{R} 3 / 6,4 / 6$ e 4/8) e na parte superior, de cores variegadas em vermelho (10R 4/8), branco-acinzentado (10YR 8/1), amarelo-brunado (10YR 6/6 a 6/8) e bruno-amarelado-claro (10YR 6/4) devido à alteração. Possui níveis de seixos quartzosos e quartzíticos/areníticos centimétricos arredondados e fragmentos laminares violáceos. Ocorrem ainda nódulos de manganês centimétricos e arredondados. -a alterita do arenito: $215 \mathrm{~cm}+$; se inicia a partir do ponto $\mathrm{V} 2$, e se estende até o final da topossequência; é vermelho-escuro (2,5YR 4/8) variegado bruno-escuro, bruno-avermelhado, amarelado e esbranquiçado em virtude da alteração. No ponto VI 6 a textura é argilo-arenosa a argilosa. No ponto VI 5 surgem volumes vermelhos (2,5YR 6/8), vermelho-claro-acinzentados (10R 6/3), vermelhoamarelados (5YR 5/8) com contraste nítido entre eles. A textura passa em profundidade de argilosa para argilo-siltosa e argilo-arenosa, ocorrendo ainda presença de volumes de areia lavada e pontuações de manganês (milimétricos); a estrutura é maciça e a porosidade não é visível. Localmente ocorrem canais de raízes fasciculadas finas e médias bordejadas de branco, revelando a perda de finos e sobretudo de ferro.

Em síntese, o segmento médio apresenta horizonte superficial arenoso (A), seguido de horizonte subsuperficial arenoso a areno-argiloso $(E)$ sobre horizonte $\mathrm{Eb}$ (bandas onduladas) que ocorrem sobre e sob o Bt, entre as trincheiras $10 \mathrm{e}$ 3, ampliadas na trincheira 11 ( rever FIGURA 9). As bandas vão se tornando cada vez menos contrastadas em relação ao $\mathrm{Bt}$, que passa de arenoso a arenoargiloso à montante para argilo-arenoso à jusante. Lateralmente o Bt torna-se acinzentado por hidromorfia, onde termina.

Abaixo do horizonte Bt aparecem os seguintes horizontes: C1b arenoso a arenoargiloso que passa lateralmente a C1c argilo-arenoso e em profundidade ao horizonte C2 areno-argiloso e à alterita do lamito. Todos esses volumes são 
avermelhados, dispostos e assentados sobre a alterita do arenito, que é de cores variegadas.

$\mathrm{Na}$ escala microscópica, o horizonte subsuperficial (E) na TR 1 apresenta cerca de $10 \%$ de plasma, $30 \%$ de poros e $60 \%$ de esqueleto.

Os grãos aparecem ligados por pontes de plasma (estrutura gefúrica) em cerca de $35 \%$ da lâmina, formando um reticulado, cujo interior apresenta grãos de esqueleto rodeado por plasma (estrutura quitônica), atingindo cerca de 65\% da área, porém não tão visível como o reticulado que aparece no mesmo horizonte do segmento superior.

O plasma é bruno sob luz natural e sob luz polarizada é opaco (55\% do total), com domínios cintilantes (silassépico), que alcança cerca de $30 \%$ da lâmina e somente é visível sob aumentos maiores (125x); aparecem ainda restos de cutãs com extinção ausente (15\% do total), ligando grãos do reticulado e muito amarelados sob luz polarizada.

A porosidade predominante é a de empilhamento simples dos grãos.

O esqueleto se mantém como o do horizonte $E$ do segmento superior.

-o horizonte Bt, na TR 3, trecho inicial do segmento médio, apresenta cerca de $30 \%$ de plasma, $25 \%$ de poros e $45 \%$ de esqueleto.

Os grãos de quartzo estão ligados por pontes de plasma (estrutura gefúrica) predominantes $(60 \%)$ e também estão cimentados por uma matriz mais argilosa (estrutura porfírica), que atinge os cerca de $40 \%$ restantes da lâmina.

O plasma varia de vermelho-amarelo a vermelho sob luz natural e sob luz polarizada aparece opaco.

A porosidade mais importante é a de empilhamento simples dos grãos (60\%), mas há também cavidades importantes ligadas às raízes do tipo ortoporos (sem plasma orientado em suas paredes), com formas irregulares e diâmetros que variam de $0,5 \mathrm{~mm}$ a $7 \mathrm{~mm}$ (macroporos muito finos a grosseiros, mas predominando os muito finos) e são medianamente comunicantes entre si. 
O esqueleto é constituído basicamente de grãos finos de quartzo $(0,25$ a $0,125 \mathrm{~mm}$ ), com cerca de $98 \%$ de quartzo e $2 \%$ de manganês e/ou carvões. Os grãos são subarredondados, lisos e com distribuição aleatória.

Nas bandas onduladas que aparecem junto ao $\mathrm{Bt}$, o plasma total aumenta para $40 \%$, com $15 \%$ de poros e $45 \%$ de esqueleto. Predominam os grãos de quartzo cimentados por plasma (estrutura porfírica). As demais características idem, mas sob luz polarizada observa-se cutãs quase opacos somente visíveis sob maiores aumentos (125x) e que aparentemente não apresentam sinais de iluviação.

Os revestimentos argilosos (cerosidade) observados na TR 5 apareceram em forma de cutãs na porosidade cavitária bem vísiveis nas FOTOMICROGRAFIAS $8 \mathrm{a}$ e $8 \mathrm{~b}{ }^{1}$ e são do tipo crescente (de fundo de poro); apresentam contraste forte, limite nítido em relação ao fundo matricial, distribuição laminada, orientação forte, padrão estriado, interpretados como de iluviação e estão ligados à estrutura em agrupamentos de ilhas (mossépica) que é menos importante.

Na TR1, trecho final do segmento médio no $\mathrm{Bt}(\mathrm{Btg})$, a quantidade de plasma alcança cerca de $40 \%$, com $15 \%$ de poros e $45 \%$ de esqueleto, como nas bandas onduladas de montante.

Os grãos de quartzo estão totalmente cimentados por plasma (estrutura porfírica).

O plasma é vermelho-amarelo sob luz natural e sob luz polarizada apresenta $60 \%$ da área com separações plásmicas em agrupamentos de ilhas (mossépico) e no restante cutãs de poros e de grãos (40\%).

A porosidade mais importante é a de cavidades $(60 \%)$, formadas pelo arranjo normal do plasma e esqueleto (ortoporos) e também poros com plasma orientado em suas paredes (metaporos), com cerca de $40 \%$. Essas cavidades

\footnotetext{
${ }^{1}$ A PRANCHA 2 apresenta as FOTOMICROGRAFIAS 8 a 11, representativas do segmento médio da Topossequência Retiro I.
} 


\section{LEGENDA}

\section{PRANCHA 2:}

FOTOMICROGRAFIA 8 a e b- L.P. 60X. Cutãs de iluviação, alguns fissurados nas cavidades e canais com segragação fraca do ferro no horizonte Bt da TR 5. Note-se as zonações parciais de alguns dos cutãs e o seu descolamento da parede dos poros cavitários indicando más condiçöes de drenagem e retração e o arranjo circular do esqueleto ao redor do poro (centro). Note-se ainda a porosidade fissural descontínua e o desenvolvimento de cavidades conectadas, apresentando estrangulamentos e preenchimentos.

FOTOMICROGRAFIAS 9 a e b - L.N. e L.P. 80X. Cutã de iluviação de cavidade do Bt hidromórfico (Btg) da TR 1. Note-se as zonações e estriações parciais e descontínuas e o desmantelamento do cutã originando pápulas na porosidade e algumas já incorporadas pelo fundo matricial porfírico (à direita). Note-se, sob luz polarizada, que a orientação expressa pela extinção forte e contínua permanece apenas junto às paredes do poro e que a segregação do ferro é forte, formando pequenos nódulos arredondados e alongados na zona fragmentada com arranjo circular do esqueleto.

FOTOMICROGRAFIAS 10 a e b - L.N. e L.P. 60X. Cutã de iluviação do Btg da TR 1 com segregação do ferro (centro à esquerda), já separado do fundo matricial por meio de fissura perpendicular. Note-se, sob luz polarizada, a fissuração do cutã e do plasma sendo transformados em pápulas (centro à esquerda), a estrutura plásmicaesquelsépica descontinua na opacidade dominante do plasma descolorido, além da tendência de arranjo circular do esqueleto.

FOTOMICROGRAFIA 11 - Aspecto geral das litorreliquias encontradas na alterita do arenito Pirambóia da TR 1, onde o plasma é negro e porfírico, num fundo matricial também porfírico e plasma amarelo. Note-se a estratificação composta de areia mais grossa e mais fina. 
PRANCHA 2- Micromorfologia do segmento médio da Topossequência Retiro I

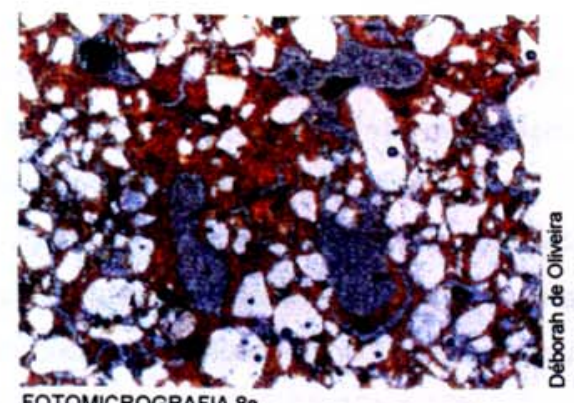

FOTOMICROGRAFIA 8a
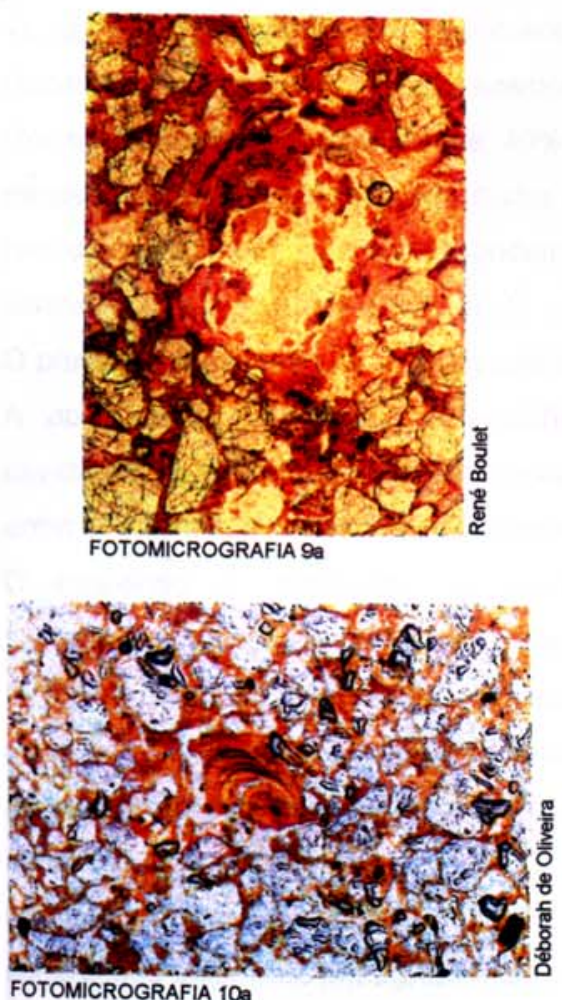

FOTOMICROC

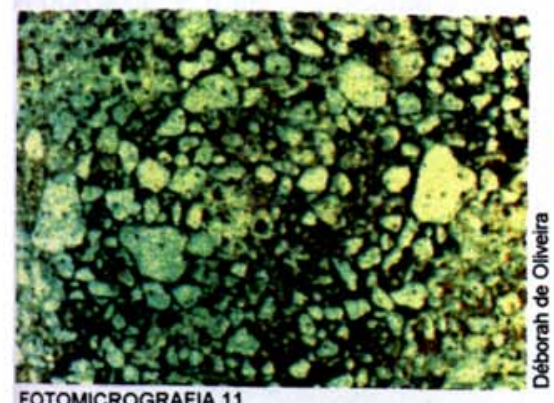

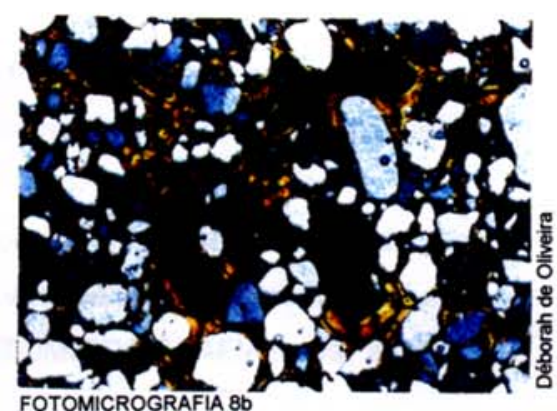
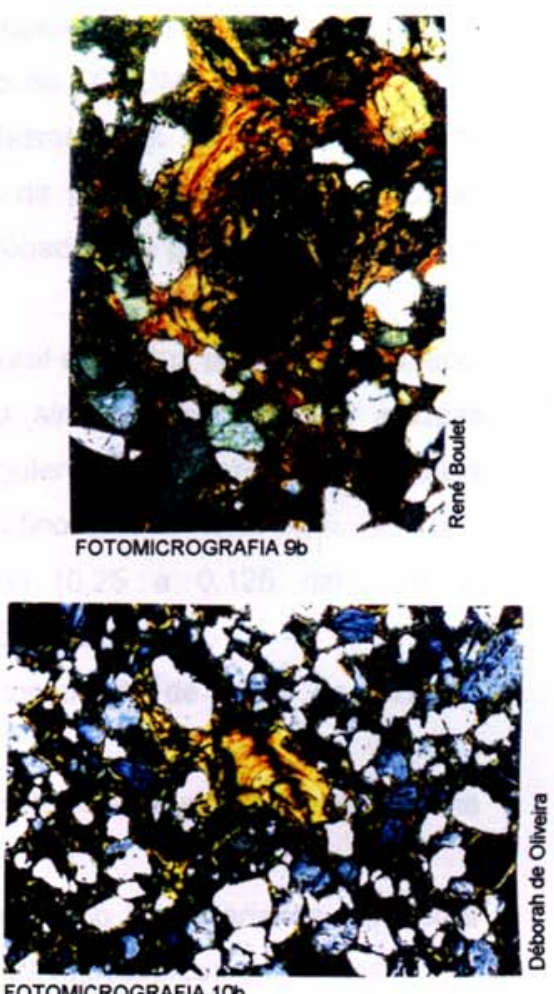

FOTOMICROGRAFIA $10 b$ 
variam de $0,5 \mathrm{~mm}$ a $2,5 \mathrm{~mm}$ (macroporos muito finos a médios), predominando os de $0,5 \mathrm{~mm}$ (muito finos) e são medianamente comunicantes entre si.O esqueleto se mantém semelhante aos anteriores.

Alguns cutãs aparecem originando pápulas, que são inicialmente separadas dos cutãs preservados por meio de fissuras e vão sendo incorporados ao fundo matricial porfírico, como aparece nas FOTOMICROGRAFIAS 9a e 9b e FOTOMICROGRAFIAS 10a e 10b.

-a alterita do arenito na TR 1 apresenta mosqueamentos que correspondem a litorrelíquias do arenito, como o exemplificado na FOTOMICROGRAFIA 11. As litorrelíquias são constituídas de $40 \%$ de plasma, $10 \%$ de poros e $50 \%$ de esqueleto, apresentando grãos numa matriz de plasma em pequenas zonas (estrutura porfírica), que correspondem a agregados de plasma mais escuro e vermelho que o do fundo matricial.

O plasma é bruno-escuro a negro sob luz natural e sob luz polarizada é opaco. A porosidade é formada de empilhamento simples dos grãos e poucas cavidades do tipo ortoporos, com formas irregulares, fracamente comunicantes entre si e com 1,35 mm em média (macroporos finos).

O esqueleto é constituido de quartzo fino $(0,25$ a $0,125 \mathrm{~mm})$, sendo subarredondados, lisos com distribuição de base aleatória.

O fundo matricial fora das litorrelíquias é constituido de cerca de $30 \%$ de plasma, $30 \%$ de poros e $40 \%$ de esqueleto.

Apresenta um arranjo onde os grãos do esqueleto estão numa matriz de plasma (estrutura porfírica).

O plasma é vermelho-amarelo sob luz natural e sob luz polarizada apresenta separações plásmicas em agrupamentos de ilhas (mossépico).

A porosidade mais importante é a de cavidades do tipo ortoporos, semelhantes às das litorrelíquias.

Os grãos do esqueleto são semelhantes aos existentes nas litorrelíquias. 
Em síntese, o segmento médio apresenta um horizonte subsuperficial E com cerca de $10 \%$ de plasma; com reticulado semelhante ao segmento superior, formado por esqueleto ligado por pontes de plasma (estrutura gefúrica) e com esqueleto rodeado por plasma (estrutura quitônica) em seu interior; a porosidade mais importante é a de empilhamento simples dos grãos. O horizonte Bt à montante, na TR 11 aparece progressivamente entre as bandas superficiais, tornando-se cada vez mais nítido e espesso para jusante em relação às bandas onduladas ao longo dessa trincheira. A TR 3 apresenta cerca de $30 \%$ de plasma opaco e aparentemente não cutânico e uma organização onde os grãos do esqueleto estão ligados por pontes de plasma (estrutura gefúrica) predominantemente; a porosidade mais importante é a de empilhamento simples dos grãos, mas há também cavidades ligadas às raízes. As bandas do Bt apresentam cerca de $40 \%$ de plasma cutânico (visto sob aumentos maiores - 125x), com esqueleto cimentado por plasma (estrutura porfírica); a porosidade mais importante é a de empilhamento simples dos grãos, mas há também algumas cavidades; observa-se cutãs de poros e de grãos quase opacos sob luz polarizada. Na TR 5 aparecem cutãs de iluviação nas cavidades com contraste forte e limite nítido em relação ao fundo matricial. Na TR 1, à jusante, a quantidade de plasma total, que é iluvial, passa a cerca de $40 \%$, com esqueleto cimentado por plasma (estrutura porfírica); a porosidade mais importante é a de cavidades e há vários cutãs de poros e de grãos inteiros e outros fragmentados por influência da hidromorfia. Esses cutãs aparecem originando pequenos fragmentos na porosidade (pápulas) que são incorporados ao fundo matricial porfírico. O horizonte de profundidade (alterita do arenito) apresenta litorrelíquias com cerca de $40 \%$ de plasma não cutânico e esqueleto cimentado por plasma (estrutura porfírica).

A transição para o segmento inferior se dá pelo desaparecimento da cobertura podzólica, onde o horizonte $\mathrm{Bt}$ aparece hidromorfizado e pelo aparecimento de 
perfis com sequência de horizontes A sobre Eg, seguidos da alterita do arenito (até o Córrego do Retiro, à jusante).

\section{Segmento inferior:}

Neste trecho, do ponto VI 12 à TR 9, ocorre o solo similar a Litossolo, cujas trincheiras estudadas (TR 7 e TR 4) estão representadas na FIGURA 11, que se caracterizam macroscopicamente como a seguir:

-o horizonte superficial (A): 0-20cm; é bruno-acinzentado muito escuro (10YR 3/2); arenoso, rico em volumes milimétricos de areia lavada; estrutura fraca pequena poliédrica; porosidade intergranular forte.

-o horizonte subsuperficial $(E)$ : $20-45 \mathrm{~cm}$; bruno-amarelado-escuro a brunoamarelado (10YR 4/4 e 5/4) com pontuações bruno-acinzentadas; textura arenosa; estrututa maciça.

-o alterita com justaposição: 45-55cm; corresponde à justaposição de volumes de 5 a $15 \mathrm{~cm}$ de cor vermelho (10R 4/8) e amarelo-avermelhado (7,5YR 6/8) bordejados de material branco; textura arenosa fina; estrutura fraca média poliédrica; porosidade não visível. Esses blocos estão separados entre si por um material cinzento-brunado-claro (10YR 6/2), formando uma rede de 1 a $2 \mathrm{~cm}$; arenosa a areno-argilosa; porosidade tubular com presença de raízes.

-a alterita do arenito: $55 \mathrm{~cm}+$; neste trecho, continua apresentando as mesmas características do trecho médio da topossequência.

Em síntese, o segmento inferior apresenta horizonte superior arenoso (A), horizonte subsuperficial arenoso (E) sobre alterita com justaposição, que apresenta matriz bruna intercalada por volumes de cores variegadas com textura arenosa a areno-argilosa para a matriz bruna e arenosa muito fina para os volumes de cores variegadas, que se assemelha a alterita, que aparece em profundidade. Desse trecho em diante da vertente até a jusante aparecem os Litossolos propriamente ditos. 
FIGURA 11-Perfis do Litossolo do segmento inferior da Topossequência Retiro I

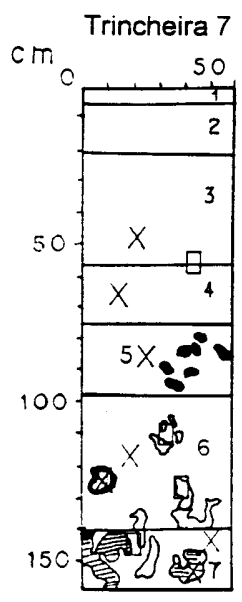

Trincheira 4

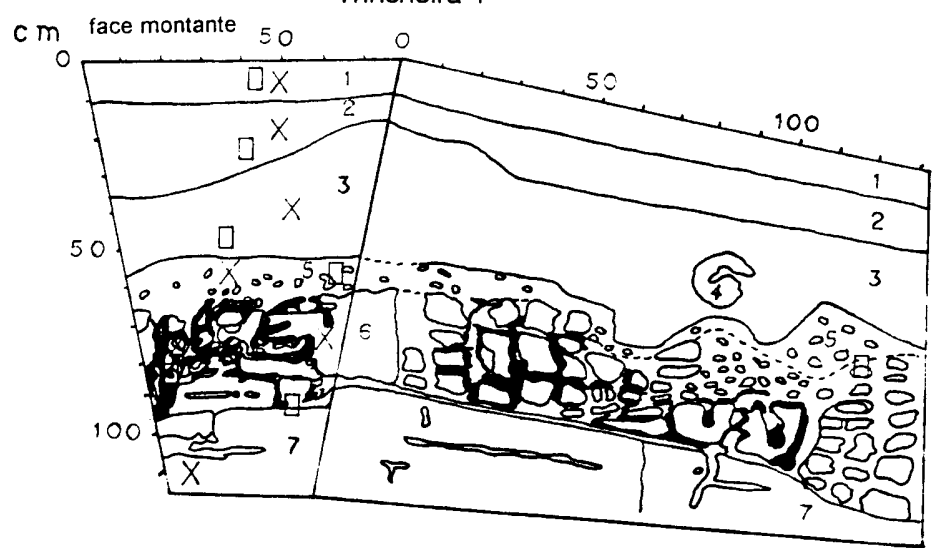

LEGENDA

$\because$ volumes vermelho-escuros do arenito

alterita do arenito estratificada

- volumes bruno-acinzentados

$\checkmark$ volumes amarelo-avermelhados

- transição entre horizontes

$X$ coleta de amostra deformada

7 coleta de amostra indeformada

1 horizontes ou volumes *

* os números correspondem à descrição dos horizontes por trincheira em ANEXO II 
Na escala microscópica, o horizonte subsuperficial (E) é constituido de $5 \%$ de plasma, $35 \%$ de poros e $60 \%$ de esqueleto. Na passagem deste horizonte para alterita do arenito, a quantidade de plasma aumenta para $15 \%$, diminuindo a porosidade para $25 \%$.

Pode-se ver que os grãos de esqueleto estão ligados por pontes de plasma (estrutura gefúrica) e que na passagem para o arenito a tendência é de que os grãos estejam envolvidos por plasma (estrutura porfírica).

O plasma é amarelo sob luz natural e sob luz polarizada apresenta nitidamente domínios cintilantes (silassépico) e plasma orientado ao redor dos grãos (esquelsépico) dominante, como mostram as FOTOMICROGRAFIAS 12a e $12 b^{1}$.

A porosidade é constituida de cavidades, que são do tipo ortoporos, na maior parte ligadas às raízes, são irregulares, variam de $0,5 \mathrm{~mm}$ a $2,5 \mathrm{~mm}$ (macroporos muito finos a médios).

O esqueleto é constituido de quartzo fino $(0,25$ a $1,125 \mathrm{~mm})$, subarredondados a subangulares lisos, com pequena contribuição de manganês e/ou carvões e distribuição aleatória.

-a alterita com justaposição é constituída por 2 zonas: uma que corresponde a um material de cores variegadas amarelo-avermelhado com periferia branca que é envolvido por outra que corresponde a uma rede bruno-acinzentada-clara. A zona de cores variegadas é constituida por $25 \%$ de plasma, $15 \%$ de poros e $60 \%$ de esqueleto.

O esqueleto está distribuido numa matriz de plasma (estrutura porfírica).

Há dois tipos de plasma: um amarelo-avermelhado e outro vermelho a negro, que sob luz polarizada apresentam-se, respectivamente, com plasma não orientado (argilassépico) e opaco, como mostra a FOTOMICROGRAFIA 13. A porosidade é contituída de fissuras, que aparecem no interior da zona de cores variegadas e na passagem para a zona bruno-acinzentada-clara.

${ }^{1}$ A PRANCHA 3 apresenta as FOTOMICROGRAFIAS 12 a 15, representativas do segmento inferior da Topossequência Retiro I. 


\section{LEGENDA}

\section{PRANCHA 3:}

FOTOMICROGRAFIAS 12 a e b - L.N. e L.P. 80X. Plasma amarelo cimentando grãos de esqueleto fino (estrutura porfírica) do horizonte $\mathrm{E}$ da TR 4, com forte porosidade de empilhamento. Note-se, sob luz polarizada, a estriação do plasma em torno do esqueleto, assim como as fraturas, as figuras de dissoluçāo dos grãos de quartzo e a pseudomorfose da mica e do plagioclásio pouco alterados (centro).

FOTOMICROGRAFIA 13 - L.N. 30X. Aspecto geral da alterita com justaposição da TR 4. Note-se um plasma amarelo, que corresponde à zona brunoacinzentada-clara e um plasma negro a vermelho, que corresponde à zona com cores variegadas. Note-se ainda que o fundo matricial das duas zonas é porfírico.

FOTOMICROGRAFIAS 14 a e b - L.N. e L.P. 80X. Plasma amarelo da alterita do arenito da TR 4, com domínios cintilantes (silassépico) e orientações ao redor do esqueleto (esquelsépico). Note-se a presença de minerais primários preservados no interior do fundo matricial (muscovita, plagioclásio).

FOTOMICROGRAFIA 15 - L.P. 30X. Estratos alternados de areia fina e média com plasma amarelo e negro da alterita do arenito da TR 7. Note-se a heterogeneidade do fundo matricial porfírico (variegado), constituido por zonas nodulares associadas ao esqueleto fino e zonas acinzentadas com plasma buno-acinzentado e esqueleto médio predominante. 
PRANCHA 3- Micromorfologia do segmento inferior da Topossequência Retiro I
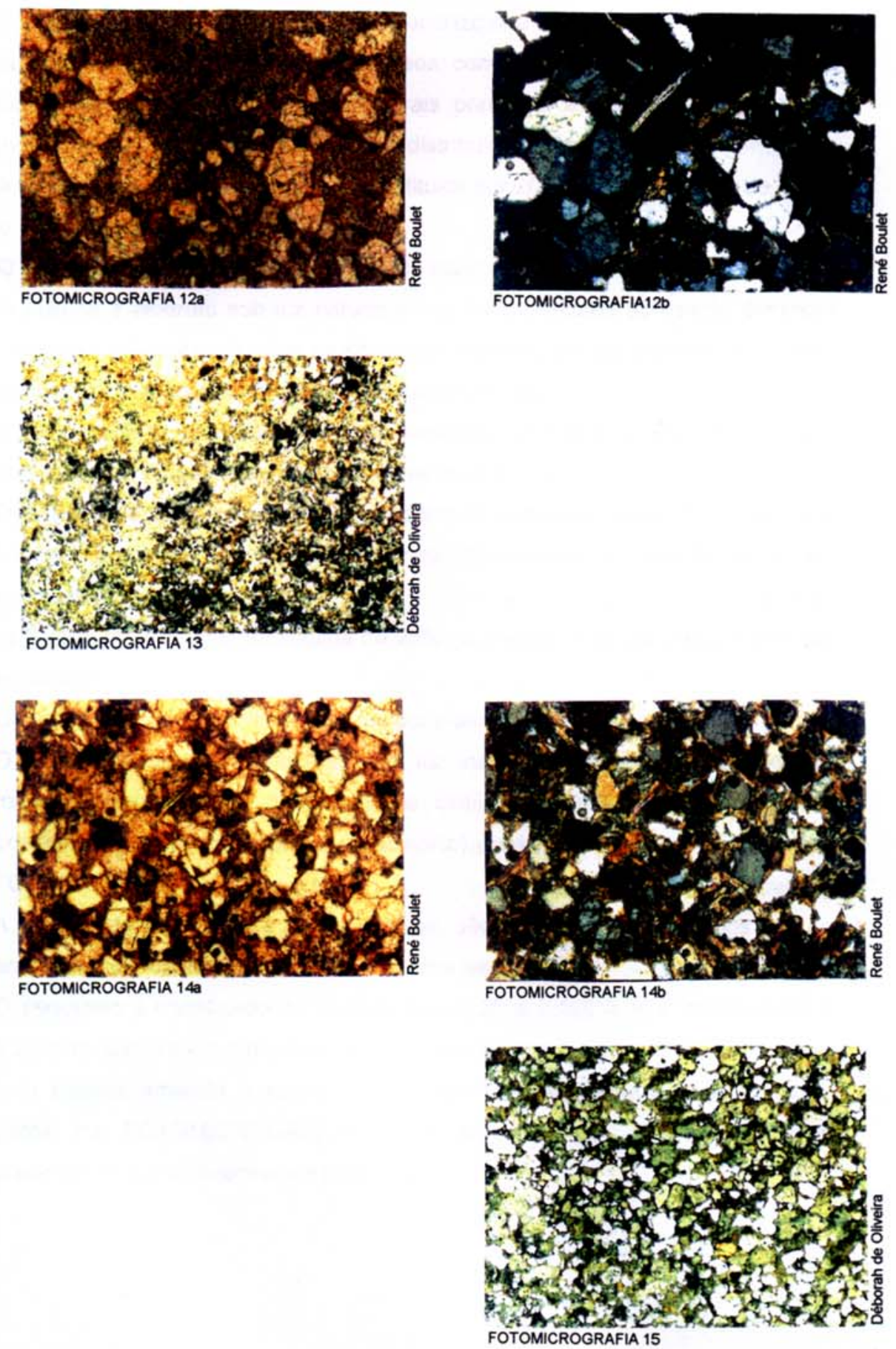
O esqueleto é constituido de grãos de quartzo fino $(0,25$ a $0,125 \mathrm{~mm})$, variando de subarredondados a subangulares lisos, com contribuição de outros minerais como manganês e/ou carvões, minerais primários ainda preservados como muscovita e plagioclásio e apresentam distribuição aleatória.

A zona bruno-acinzentada-clara é constituida por $20 \%$ de plasma, $35 \%$ de poros e $45 \%$ de esqueleto.

O esqueleto está distribuido na matriz de plasma (estrutura porfírica).

O plasma é amarelo sob luz natural e sob luz polarizada apresenta domínios cintilantes (silassépico), mas predomina o plasma com agrupamentos de ilhas (mossépico) em toda a zona bruno-acinzentada-clara.

A porosidade é constituida de empilhamento complexo e algumas fissuras, localizadas principalmente no contato das duas zonas.

O esqueleto é muito semelhante ao da zona de cores variegadas. É possível ver minerais primários intemperizáveis ainda preservados em ambas as zonas, como muscovita e plagioclásio.

-a alterita do arenito é constituida de $25 \%$ de plasma, $15 \%$ de poros e $60 \%$ de esqueleto.

Os grãos de quartzo estão envolvidos por plasma (estrutura porfírica).

O plasma é negro e amarelo sob luz natural e sob luz polarizada é, respectivamente opaco, com domínios cintilantes (silassépico) e esqueleto orientado ao redor dos grãos (esquelsépico) predominante, como aparece nas FOTOMICROGRAFIAS 14a e 14b.

A porosidade dominante é a de ortoporos, são macroporos muito finos que se encontram principalmente onde há o plasma amarelo.

$\mathrm{O}$ esqueleto é constituido de quartzo fino $(0,25$ a $0,125 \mathrm{~mm})$ e médio $(0,50 \mathrm{a}$ $0,25 \mathrm{~mm}$ ) subarredondados lisos em estratos alternados de areia fina e média, com plasma amarelo e negro, distribuídos aleatoriamente nesses estratos, vistos na FOTOMICROGRAFIA 15 e presença de minerais primários preservados como muscovita e plagioclásio. 
Em síntese, o segmento inferior apresenta horizonte subsuperficial E pobre em plasma (cerca de $5 \%$ ), mas aumentando para $15 \%$ em profundidade no contato com a alterita do arenito, que apresenta $25 \%$ de argila e estratificação de plasma negro e amarelo com areia média e fina. A matriz bruna da alterita de justaposição apresenta cerca de $20 \%$ de plasma e grãos distribuídos numa matriz de plasma amarelo (estrutura porfírica); os volumes de cores variegadas apresentam cerca de $25 \%$ de plasma branco, amarelo-avermelhado, vermelho, onde os grãos estão distribuídos numa matriz de plasma (estrutura porfírica), não apresentando plasma cutânico, mas é visível a presença de minerais primários intemperizáveis ainda preservados dentro do fundo matricial.

\subsubsection{Síntese da macro e micromorfologia da Topossequência Retiro I}

O que se percebe de modo geral, no que se refere à macromorfologia, pelas descrições e pela FIGURA 7 é que:

1- Os horizontes $\mathrm{C} 1 \mathrm{a}, \mathrm{C} 1 \mathrm{~b}$ e $\mathrm{C} 2$ do segmento superior da vertente apresentam limites relativamente angulosos entre si, cuja geometria não parece ter relação com a topografia da vertente atual; esse arranjo lembra uma seção de estratificação cruzada semelhante à arenito Pirambóia. Seus teores de argila aumentam em profundidade e lateralmente rumo ao lamito e se de fato são litoherdados, sugerem a idéia de ambiente de deposição mais úmido com mais finos, como eram os interdunários (SOARES, 1973);

2- Os horizontes dos segmentos médio e inferior são concordantes com a topografia da vertente atual, com exceção do lamito;

3- Os horizontes superficiais (A, E) são também concordantes com a vertente atual, apresentam espessura quase que constante e grande quantidade de areia lavada em toda a sua extensão; 
4- O horizonte Eb (bandas onduladas) apresenta um material interbandas mais arenoso no topo do perfil e menos arenoso para a base, onde as bandas se tornam cada vez menos contrastadas nesse sentido;

5- $\mathrm{O}$ horizonte $\mathrm{Bt}$ inicia-se à montante (TR10, TR 3 e TR11) por um espessamento e coalescência de bandas onduladas, que aparecem acima, no seu interior e abaixo deste e torna-se cada vez mais estruturado para jusante;

6- No final do segmento médio, na transição do horizonte E com o Btg aparecem relíquias avermelhadas do Btg e este começa a apresentar interpenetração com o $\mathrm{E}$ (bolsões de areia lavada) e progressivamente sinais de hidromorfia, tornando-se mais espesso e apresentando parentesco com a alterita do arenito na base, confirmando sua degradação e substituição pelos perfis onde aparece a alterita com justaposição de rede bruno-acinzentada clara englobando volumes com cores variegadas, seguidos da alterita do arenito (ANEXO II - TR 1);

7- O horizonte C1c é o que apresenta o maior teor de argila dentre os C, iniciando-se junto ao lamito e terminando na altura da TR 5. Este horizonte ainda apresenta seixos e nódulos de manganês, provavelmente litoherdados;

8- A alterita com justaposição é concordante com a topografia atual da vertente e desenvolve-se sobre a alterita de cores variegadas do arenito, indicando intensa hidromorfia pela coloração bruno-acinzentada clara e sugerindo confinamento do lençol, pelo menos até a ruptura de declive, que marca o final da Topossequência Retiro I.

O resultado das observações micromofológicas, expresso nas descrições, nas PRANCHAS 1, 2 e 3, nas TABELAS 1, 2 e 3 (ANEXO III) e nas FIGURAS 12 e 13 adiante, de modo geral mostram que:

1- A quantidade de plasma está diretamente relacionada à porosidade, como demonstra a FIGURA 12, pois onde há mais plasma cimentando grãos (estrutura porfírica) a porosidade diminui e vice-versa, como o observado nas 
FIGURA 12 - Gráficos da distribuição percentual de plasma, esqueleto, poros e das estruturas de base dos perfis representativos da Topossequência Retiro I

\section{Segmento superior}

Areia Quartzosa com bandas onduladas

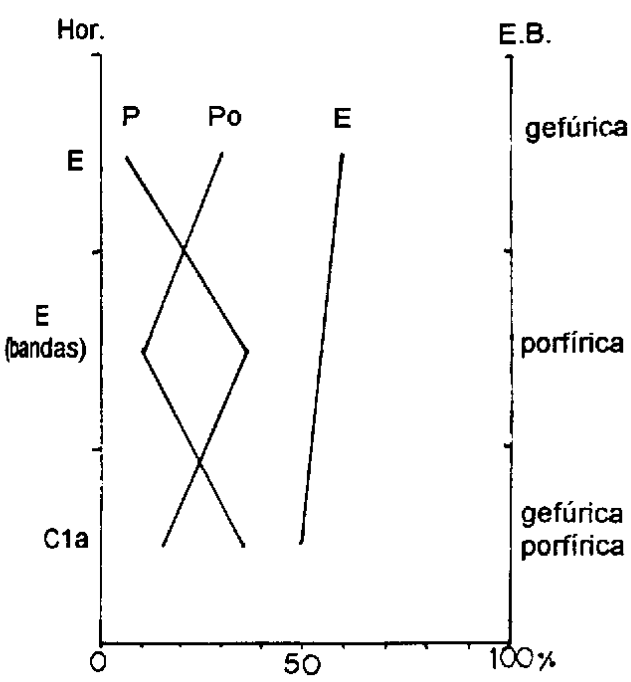

Segmento médio (final)

Podzólico Vermelho-Amarelo(Btg)

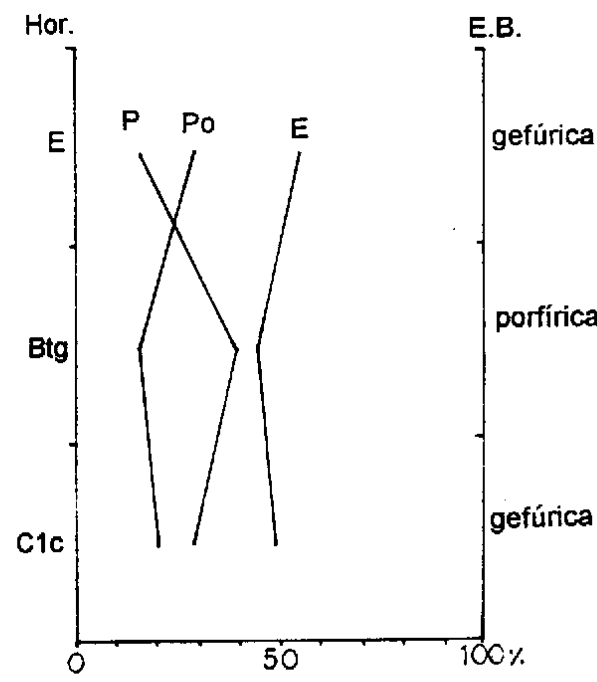

$P=$ plasma $E=$ esqueleto $P o=$ poros

E.B.= estruturas de base
Segmento médio (início)

PodzólicoVermelho-Amarelo(Bt)

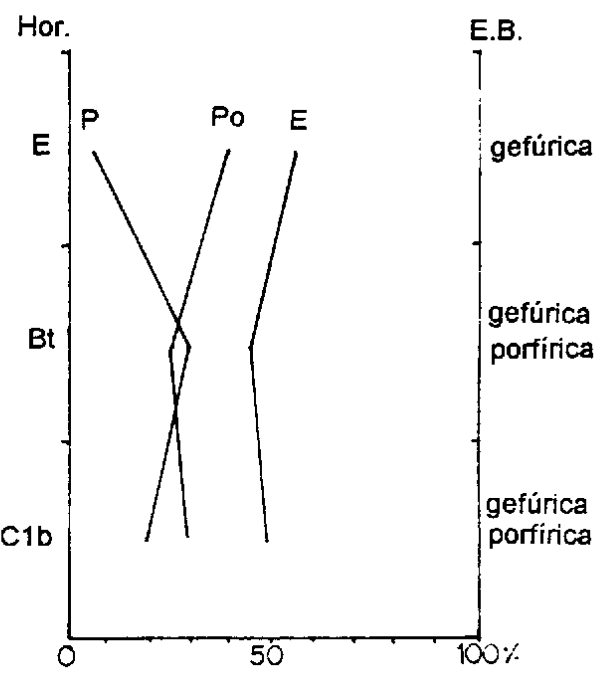

Segmento inferior

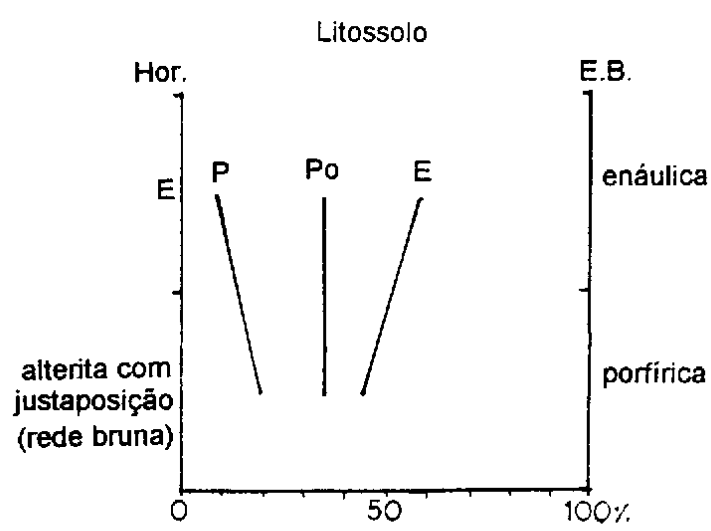


bandas e no $\mathrm{Bt}$ e $\mathrm{Btg}$, que atingem o máximo de argila e a porosidade diminui muito. As bandas onduladas do horizonte Eb apresentam aumento de plasma em relação aos volumes interbandas do mesmo horizonte, ao $\mathrm{E}$ e ao C1a, como mostra a FIGURA 13 e PRANCHA 1, fazendo com que as estruturas de base gefúricas no volume interbandas passem a porfíricas nas bandas e no Bt;

2- A porosidade de empilhamento do volume interbandas e horizonte $\mathrm{C} 1 \mathrm{a}$ passa de uma porosidade de empilhamento a uma macroporosidade cavitária irregular e de canais nas bandas e no Bt (FIGURA 13), sedes da acumulação de argila por iluviação (cutãs de iluviação);

3- Na base das bandas e no Bt aparece uma pedoturbação geradora de uma porosidade microfissural e fissural e também de pápulas, que inicialmente ficam próximas aos restos de cutãs relativamente preservados e colados às paredes dos poros e depois são incorporados ao novo fundo matricial porfírico, como ilustram as FOTOMICROGRAFIAS 6a e 6b, 9a e 9b e 10a e 10b;

4- O fenômeno de argiluviação é notável e ainda está relativamente preservado nas bandas bem como no $\mathrm{Bt}$, mas é notável também a segregação do ferro, pós-deposicional, nos topos das bandas e do Bt, revelando condições de encharcamento, pelo menos temporário. Essa segregação leva a um comportamento de retração/expansão, responsável pelo descolamento das feições cutânicas das paredes dos poros e sua fragmentação, como o observado nas FOTOMICROGRAFIAS 10a e 10b; indica também um certo bloqueio da drenagem vertical nos perfis;

5- Os fenômenos de degradação (desmantelamento, descoloração, estruturação plásmica) relatados ocorrem predominantemente no topo e na base das bandas onduladas e do $\mathrm{Bt}$, revelando uma dinâmica de formação e destruição dessas feições e do horizonte Eb, como mostra a FIGURA 13;

6- Os horizontes C, como mostram as TABELAS 1, 2, 3 e a FIGURA 12, apresentam aumento de plasma vertical e lateralmente, com a passagem das 
FIGURA 13 - Síntese das estruturas micromorfológicas dos principais horizontes da Topossequência Retiro 1

Segmento Superior

Horizonte

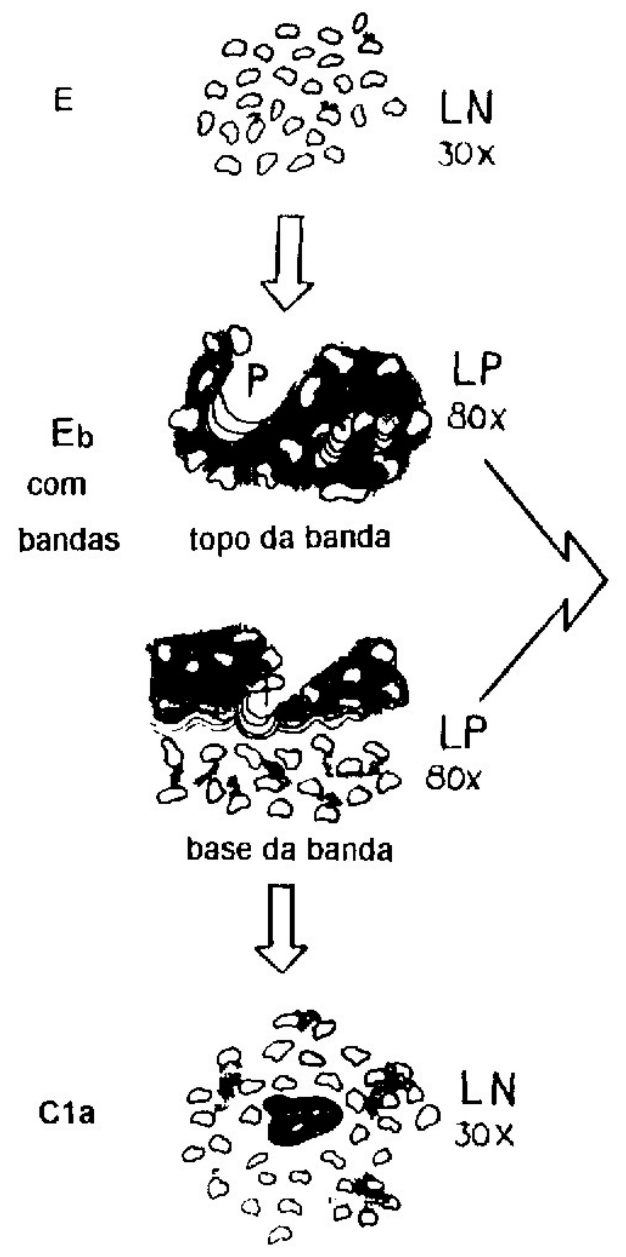

Segmento Médio

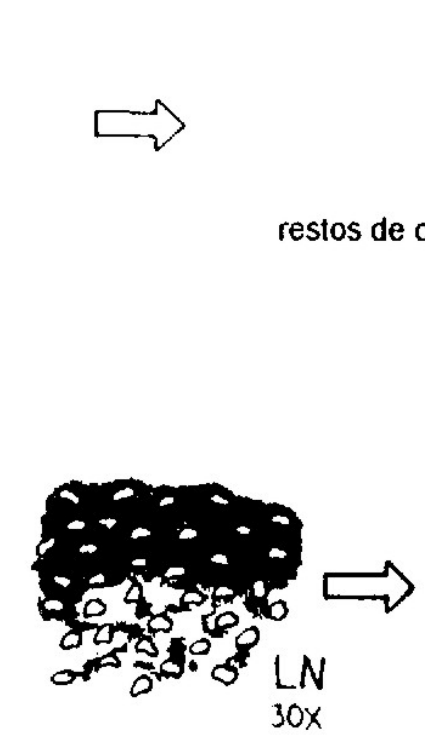

Bt com banda (pontes ligando grãos)
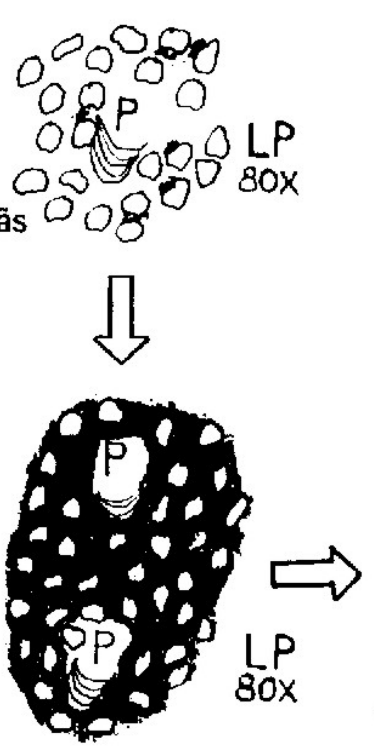

Bt sem banda
Segmento Inferior
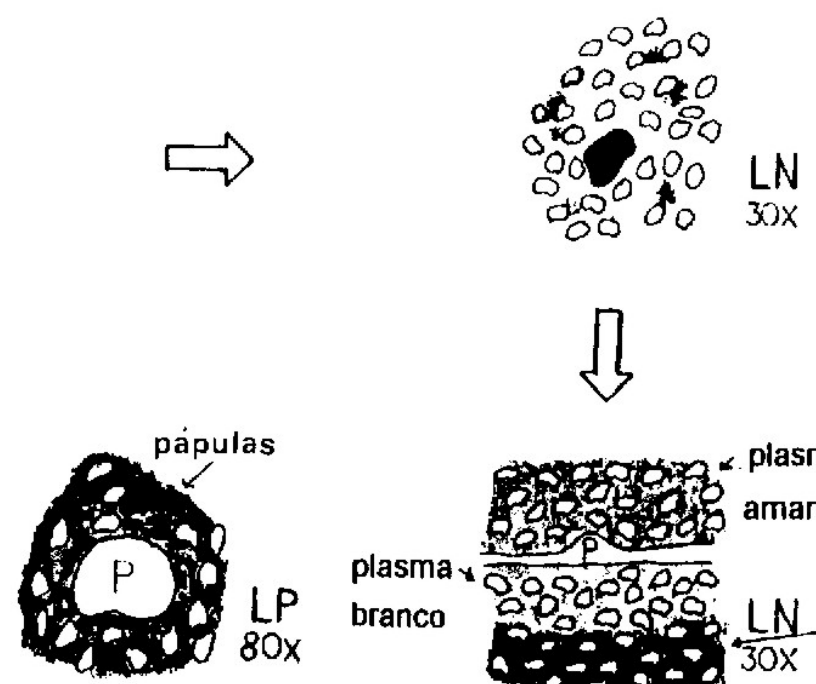

argilã se destruindo final do Btg

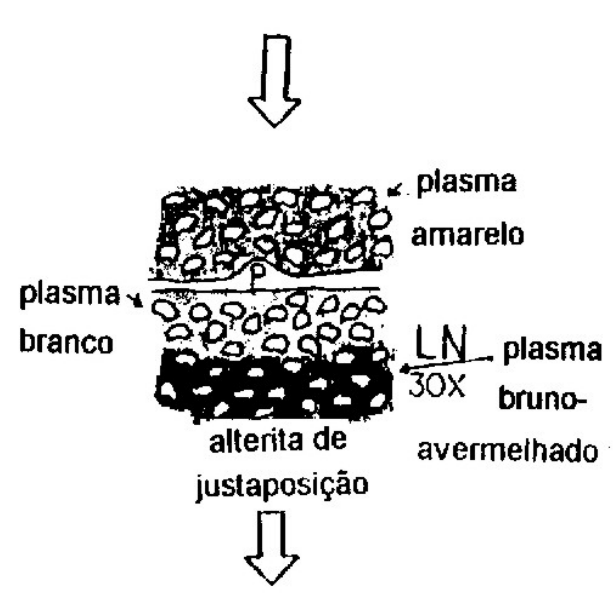

\section{LEGENDA}

0 esqueleto
plasma

(P) poro

L.N. Luz Natural

L.P. Luz Polarizada

30X Aumentos ópticos

$$
00 \text { a } 000
$$

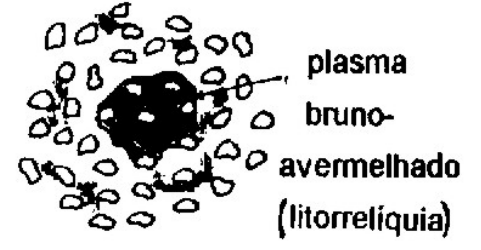

alterita do arenito
(1) cutãs de iluviação

- pápulas

- carvão

$\Leftrightarrow$ direção da evolução 
estruturas de base gefúricas para as porfíricas, além da presença das estruturas plásmicas opacas, não revelando esforços ou tensões, o que reforça a idéia de litodependência;

7-A presença de minerais primários (micas) relativamente preservados nos horizontes $\mathrm{E}$ e alterita do arenito do segmento inferior, como mostra a PRANCHA 3, confirmam também a idéia de litodependência, além da ausência de esforços ou tensões do plasma de alteração;

8- No segmento inferior, a hidromorfia comanda as mobilizações, sobretudo do ferro, criando feições nodulares na alterita do arenito, envolvidos por zonas de perdas, tanto em rede como em volumes, dando origem à alterita com justaposição de uma matriz bruna-acinzentada, que encontra-se deferrificada e mostra separações plásmicas em domínios cintilantes (silassépica). Esse plasma de alteração descolorido, manchado e com extinções ondulantes revela deformações ao lado do plasma ferruginizado, escuro opaco e onde há hidromorfia (segregação do ferro), como mostra a FOTOMICROGRAFIA 13. Trata-se, portanto, de um processo de alteroplasmação por hidromorfia, típico de ambiente relativamente confinado.

A FIGURA 13 consiste numa tentativa de mostrar a evolução vertical e lateral das organizações micromorfológicas em seus aspectos mais relevantes.

Nota-se que no segmento superior há predomínio de esqueleto ligado por pontes de plasma (estrutura gefúrica) e que passa a grãos cimentados por plasma nas bandas, com uma participação importante de cutãs de iluviação tanto no topo como na base das bandas, voltando a esqueleto ligado por pontes de plasma (estrutura gefúrica) no material interbandas e no horizonte $\mathrm{C} 1 \mathrm{a}$, com ausência de cutãs.

A evolução lateral das bandas onduladas demonstra que no início do segmento médio elas apresentam grãos cimentados por plasma (estrutura porfírica) muito mais fechada do que no Bt ainda ligado a essas bandas, visto sob aumentos menores $(30 x)$. Sob aumentos maiores $(80 x)$ nota-se a presença de cutãs 
orientados no Bt e que para jusante, no Btg, aparecem fragmentados originando pequenas pápulas na porosidade devido à hidromorfia.

No segmento inferior há ausência de plasma cutânico, com a participação de plasma de alteração.

\subsection{Estudo Analítico}

\subsubsection{Granulometria}

A partir dos dados apresentados no QUADRO 4 (ANEXO I), relativos aos resultados da análise granulométrica, foram elaborados gráficos de variação textural com valores acumulados por perfil, da argila, silte fino, silte grosso, areia fina e areia grossa (PRANCHA 4 - ANEXO IV), curvas de isovalores da argila, incluindo as amostras das sondagens (FIGURA 14) e da relação textural areia fina/areia grossa (FIGURA 15), tabela da relações texturais B/A e de outros horizontes em relação aos horizontes A e E (TABELA 4).

Os gráficos das trincheiras SPFR 8 e 14 foram confeccionados a partir de amostras coletadas com intervalo definido (horizontes) e procuraram ressaltar a presença das bandas onduladas.

Observando-se os gráficos das trincheiras SPFR 8 e 14, nota-se que as bandas onduladas apresentam mais argila que o restante do perfil, atingindo um máximo de $19 \%$ a $150 \mathrm{~cm}$ de profundidade na trincheira SPFR 8 e 15,9\% a 160 cm de profundidade na trincheira SPFR 14.

Os gráficos mostram que todos os horizontes $C$ apresentam mais argila que os demais horizontes ( $A, E)$, com exceção da alterita do lamito, que apresenta a maior porcentagem de argila de toda a topossequência, atingindo 47,9\%.

O horizonte Bt não é facilmente identificável através dos dados granulométricos, pois não chega a formar um "ventre" bem definido de argila, no início do segmento médio, onde ele aparece no campo, mas somente no final deste 
segmento, a partir do ponto $\mathrm{VI} 4$. Os teores de argila do Bt parecem com os dos horizontes $\mathrm{C}$, que apresentam aumento de argila em profundidade e para jusante. O Bt no ponto $\vee 5 a$ apresenta $13 \%$ de argila a $140-150 \mathrm{~cm}$ de profundidade, o horizonte C1b apresenta $14,3 \%$ de argila a $190-200 \mathrm{~cm}$ de profundidade e o horizonte C2 apresenta um máximo de 16,1\% de argila a 390$400 \mathrm{~cm}$ de profundidade.

O silte fino e grosso se mantêm com teores quase que constantes e em porcentagens muito reduzidas em toda a topossequência, atingindo o máximo de $7,3 \%$ (silte grosso) no ponto $\vee 3 \mathrm{~b}$ a $290-300 \mathrm{~cm}$ de profundidade, na alterita do lamito. Daí em diante, os teores não chegam a atingir $3 \%$. O silte fino atinge um máximo de $16,5 \%$ no ponto $\vee 3 a$ a $290-300 \mathrm{~cm}$ de profundidade, no lamito. Portanto, é no lamito que se encontram os maiores teores de silte.

Com relação à areia fina, esta se mantém com teores sempre elevados em todos os perfis da topossequência, variando entre 60 e 70\%, não apresentando uma tendência a aumento ou diminuição ao longo dos perfis. $\mathrm{O}$ teor mais baixo $(30,1 \%)$ encontra-se no ponto $\mathrm{V} 3 \mathrm{a}$ a $290-300 \mathrm{~cm}$ de profundidade, na alterita do lamito, justamente onde o valor de silte fino atinge seu máximo.

Os teores de areia grossa também se mantém constante em todos os perfis da topossequência, com teores variando entre o mínimo de 12,7\% (no ponto $\vee 5$ ) até o máximo de $21,4 \%$ (no ponto $\vee 1$ ) até o ponto $\vee 3 a$, onde há as maiores oscilações no mesmo ponto variando de $1,7 \%$ (290-300 $\mathrm{cm}$ de profundidade) a $33 \%$ (400-410 $\mathrm{cm}$ de profundidade). Os teores mais elevados de areia grossa estão na alterito do arenito e atingem $54,1 \%$ no ponto VI 4 .

No ponto $\vee$ 3a ocorre a maior oscilação da curva de areia fina, com diminuição desta e também da areia grossa e aumento da argila em profundidade, também associada a alterita do lamito.

$\mathrm{Na}$ base dos pontos VI 4 e VI 12 diminui a areia fina e aumenta a areia grossa, na alterita do arenito. Daí para jusante a areia fina volta a predominar em relação à areia grossa. 
Em síntese, a rocha caracteriza-se pela maior participação de areia grossa (com exceção da alterita do lamito) dando-se o inverso nos horizontes dos solos; já a argila tem participação mais importante no Bt e nos C, embora não caracterize propriamente um "ventre", salvo no final do Bt. Na passagem do horizonte Eb para o Bt no ponto $\mathrm{V} 5$ os teores de argila passam de $13,4 \%$ a $16,15 \%$ em média, notando-se um aumento de argila no sentido jusante.

O silte não parece ter maiores significados.

Do ponto de vista da classificação textural, a maioria dos horizontes classifica-se como arenosos (finos).

Do ponto de vista da mobilidade eventual, é a argila que parece estar sofrendo translocações mais evidentes no segmento médio e em diante, exatamente onde se encontra o Podzólico.

Quanto às bandas onduladas dos perfis das trincheiras SPFR 14 e 8, elas apresentam-se como degraus escalonados, com aumentos crescentes em profundidade para as frações argila, areia grossa e areia fina, com exceção da base do horizonte $E$, onde são degraus invertidos para a areia fina e o silte grosso, indicando diminuição destes. Os seus teores de argila atingem 15\% no topo e aumentam até $18 \%$ na base do horizonte $\mathrm{E}$.

Quanto às curvas de isovalores de argila, pode-se notar, que de modo geral a maioria delas acompanha a topografia da vertente, com uma certa homogeneidade do material e teores situados entre 10 e 15\% (FIGURA 14). A partir do ponto $V 5$ para jusante, aparecem teores maiores que $15 \%$, coincidindo com o final do horizonte Eb e aparecimento do horizonte Bt, como foi constatado em campo.

A faixa entre os pontos $\mathrm{V} 5$ e Vl 4 é a mais diferenciada de toda a vertente e corresponde à presença de Podzólico. Ainda nesta faixa, observa-se uma concentração maior de argila em profundidade, com teores superiores a $25 \%$, onde foi encontrado alterita do lamito. A base da curva de 15\% neste trecho marca o topo da alterita do arenito reproduzindo a mesma morfologia observada em campo. Deste trecho em diante, os teores estão entre 5 e $15 \%$, onde 


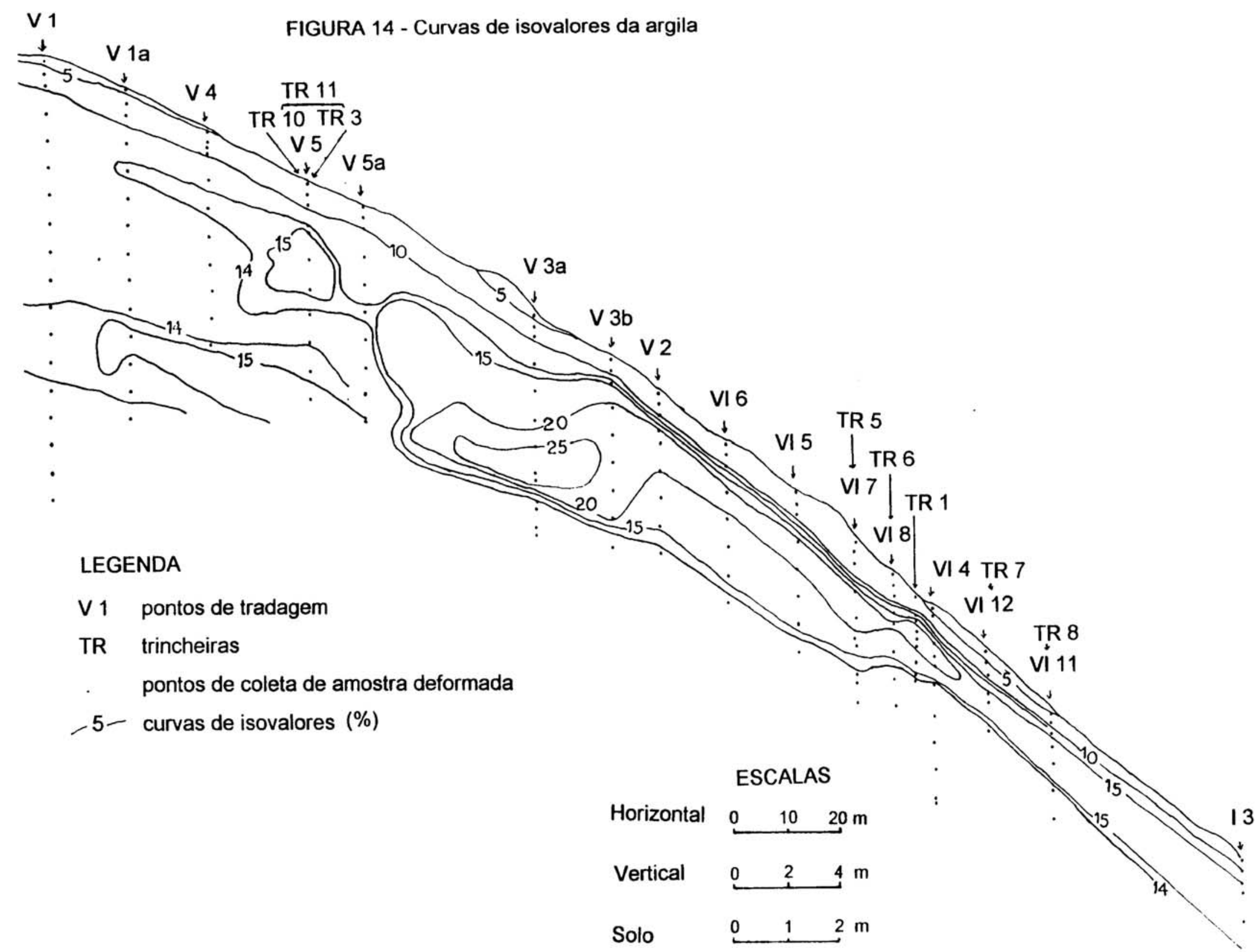


aparece o Litossolo e são também concordantes com a topografia da vertente e com os volumes observados em campo, mas com menor diferenciação que no trecho médio da topossequência.

Nas curvas de isovalores da relação textural areia fina/areia grossa (FIGURA 15) observou-se a grande homogeneidade do material no trecho montante da topossequência, com teores inferiores a 5 , mostrando um certo equilíbrio entre as porcentagens de areia fina e areia grossa. $O$ trecho médio da topossequência apresenta duas "línguas" com teores superiores a 5, que se projetam vertente acima.

Há uma maior porcentagem da areia fina em relação à areia grossa na alterita do lamito e também na base do ponto VI 4 no segmento inferior da topossequência, junto a alterita do arenito. No segmento inferior as curvas são concordantes com a topografia da vertente. 


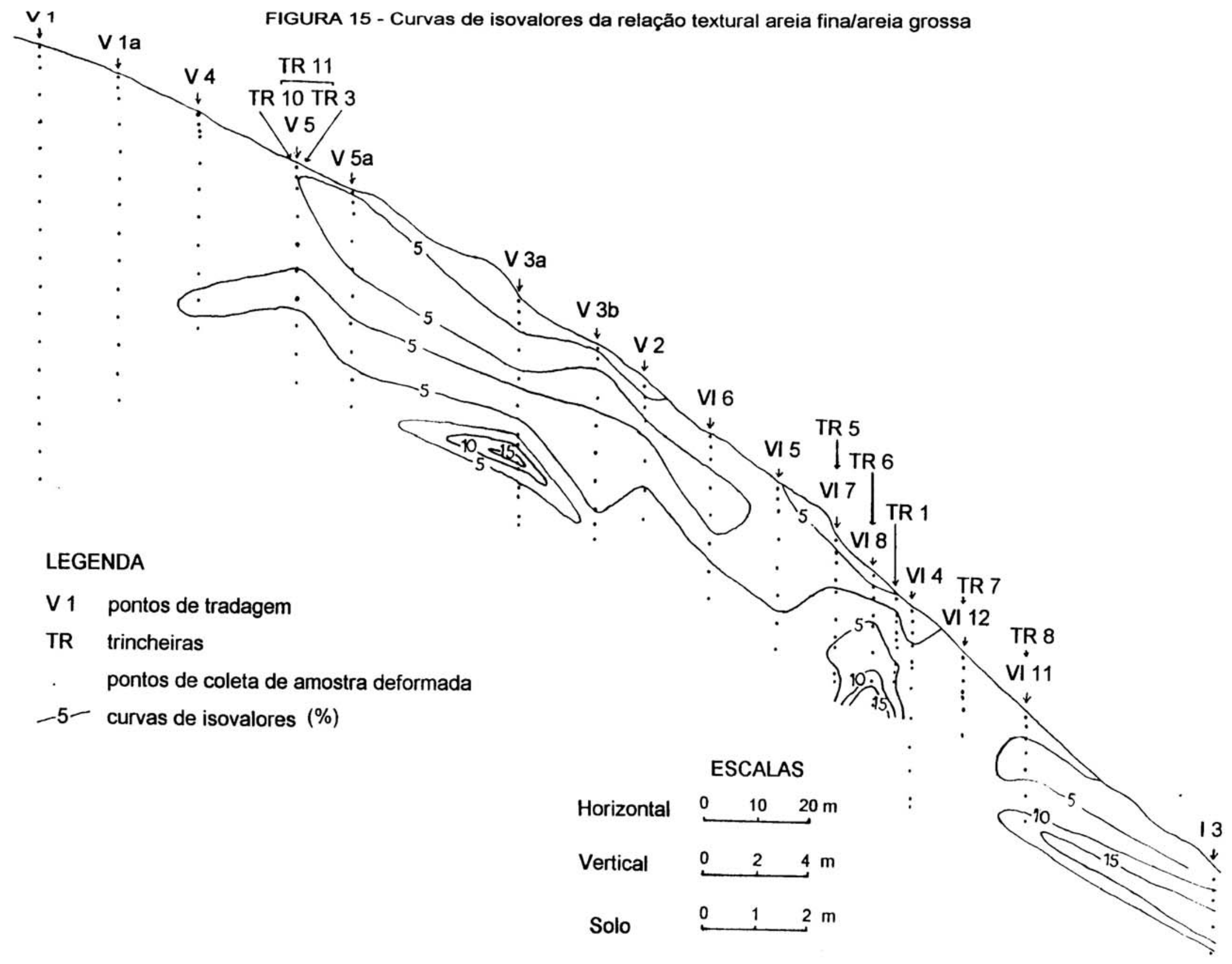


Calculando-se as relações texturais $B / A$ e de outros horizontes em profundidade em relação aos horizontes $\mathrm{A}$ e $\mathrm{E}$ e ao Bt, tem-se o apresentado na TABELA 4, a seguir:

TABELA 4 - Relações texturais B/A e de outros horizontes em relação aos horizontes A e E

\begin{tabular}{|l|l|l|}
\hline tradagem & B/A $^{*}$ & $\begin{array}{l}\text { outros } \\
\text { horizontes }\end{array}$ \\
\hline V 1 & 1,73 & 1,97 \\
\hline V 1a & 1,80 & 1,63 \\
\hline V 4 & 1,69 & 1,62 \\
\hline V 5 & 1,93 & 1,93 \\
\hline V 5a & 1,60 & 1,64 \\
\hline V 3a & 1,92 & 2,42 \\
\hline V 3b & 2,62 & 2,70 \\
\hline V 2 & 2,45 & 2,34 \\
\hline VI 6 & 3,26 & 2,82 \\
\hline VI 5 & 3,92 & 3,34 \\
\hline VI 7 & 3,38 & 2,29 \\
\hline VI 8 & 2,52 & 2,25 \\
\hline VI 4 & 3,31 & 3,31 \\
\hline VI 12 & -- & -- \\
\hline VI 11 & -- & -- \\
\hline I 3 & -- & -- \\
\hline
\end{tabular}

* média aritmética do teor de argila dos horizontes Eb (bandas onduladas), Bt dividida pela média aritmética do teor de argila dos horizontes $\mathrm{A}$ e $\mathrm{E}$.

** média aritmética do teor de argila de todos os horizontes $C$ dividida pela média aritmética do teor de argila dos horizontes $\mathrm{A}$ e $\mathrm{E}$.

A partir desta tabela pode-se observar que os valores da relação textural começam a aumentar a partir do ponto $\mathrm{V} 3 \mathrm{a}$ e/ou $\mathrm{V} 3 \mathrm{~b}$, onde o $\mathrm{Bt}$ e os 
horizontes $\mathrm{C}$ de profundidade apresentam mais argila. Outro fato importante a ser notado é que os valores da relação textural entre os outros horizontes e os horizontes A e E não se comportam diferente, demonstrando que estes outros horizontes refletem relações texturais próximas ao horizonte Bt.

Percebe-se que há um aumento da relação B/A para jusante, o que corrobora com o aumento na diferenciação textural vertical entre os horizontes $A$ e $E$ dos perfis, já assinalada, confirmando o contraste morfológico verificado em campo nessa mesma direção.

No que se refere às relações texturais da fração argila calculada entre os horizontes profundos ( $\mathrm{C}$ em geral) e os subsuperficiais $(\mathrm{Bt})$, percebe-se valores muito próximos, indicando contraste fraco entre eles, o que permite supor que entre o horizonte $\mathrm{Bt}$ e os demais horizontes subjacentes não se evidencia diferenciação textural significativa e sim estrutural, como diagnosticada em campo, além de micromorfológica.

Os teores de argila encontrados para os perfis de Areias Quartzosas intermediária para Podzólico Vermelho-Amarelo corroboram com os dados apresentados por BRASIL (1960) e OLIVEIRA \& MENK (no prelo), expostos no QUADRO 2, quando apresentam teores baixos de argila e perfis arenosos, com teores de argila menores que 15\%. A exceção está nas bandas onduladas, que apresentam teores de até $19 \%$ de argila. Os teores de areia fina maiores que $60 \%$ também confirmam o exposto por BRASIL (1960).

Os teores de argila para os Podzólicos são também similares aos encontrados por BRASIL (1960), com teores entre 5 a 13\% para o horizonte A e 15 a $29 \%$ no horizonte Bt.

\subsubsection{Análises químicas}

Os resultados das análises químicas apresentados no QUADRO 5 (ANEXO I) foram tratados através de gráficos para todos os resultados (PRANCHA 5 - 
ANEXO IV) e de curvas de distribuição dos resultados na topossequência para a soma de Bases (S), Capacidade de Troca de Cátions (T), Saturação em Bases (V\%) e Índice Ki. (FIGURAS 16, 17, 18 e 19)

Os gráficos mostram que os teores de pH encontram-se entre 3,6 (perfil VI 7, alterita do arenito) e 5,2 (perfil $\vee 1$, horizonte $\mathrm{E}$ ), refletindo solos ácidos. Em profundidade os teores se mantém constantes, em torno de 4,0.

Os teores de matéria orgânica variam de 0,6 a 2,6\% em toda a topossequência. Os maiores valores encontram-se entre 1,6 a 2,6\% no horizonte superficial $A$.

Esses solos são muito pobres em elementos trocáveis, onde se destaca o cálcio, com os maiores teores, variando entre $0,1 \mathrm{meq} / 100 \mathrm{~cm}^{3}$ (na base de todos os perfis) a $1,4 \mathrm{meq} / 100 \mathrm{~cm}^{3}$ (perfis $\vee 4,0-10 \mathrm{~cm}$ e $\mathrm{VI} 4,0-10 \mathrm{~cm}$ )

Os teores de Saturação por alumínio $(m), S, T$ e V\% levam em conta os horizontes subsuperficiais ( $\mathrm{Bt}$ e $\mathrm{C}$ ), pois que sofrem pouca ou nenhuma influência do manejo. (PRADO, 1991)

Os teores da saturação por alumínio $(m)$ encontrados nos horizontes Bt e C estão muito acima de $50 \%$, chegando a atingir o máximo de $83 \%$ no perfil VI 11 a $70 \mathrm{~cm}$ de profundidade, mostrando o caráter álico dos solos, confirmando o relatado por OLIVERIA \& MENK (no prelo) e PRADO (1991).

A Soma de Bases Trocáveis (S) nos horizontes Bt e C aparecem com teores abaixo de $1,0 \mathrm{meq} / \mathrm{cm}^{3}$ (FIGURA 16). Os teores menores que 0,5 meq/. $\mathrm{cm}^{3}$ encontram-se na Areia Quartzosa com bandas onduladas à montante e os maiores que 2,0 meq/ $\mathrm{cm}^{3}$ encontram-se no contato do Bt com a alterita do arenito, justamente onde foi encontrada no campo a hidromorfia. Os dados confirmam a pobreza dos solos.

A Capacidade de Troca de Cátions ( $T$ ) apresenta teores maiores que 6,0 $\mathrm{meq} / \mathrm{cm}^{3}$ na alterita do arenito em forma de "língua" que avança em direção ao horizonte $\mathrm{Bt}$ e $\mathrm{C} 1 \mathrm{c}$, onde se encontram os horizontes mais argilosos. (FIGURA 17)

A Saturação em Bases (V\%) apresenta teores menores que 50\% em toda a topossequência, mostrando o caráter distrófico dos solos. (FIGURA 18) 


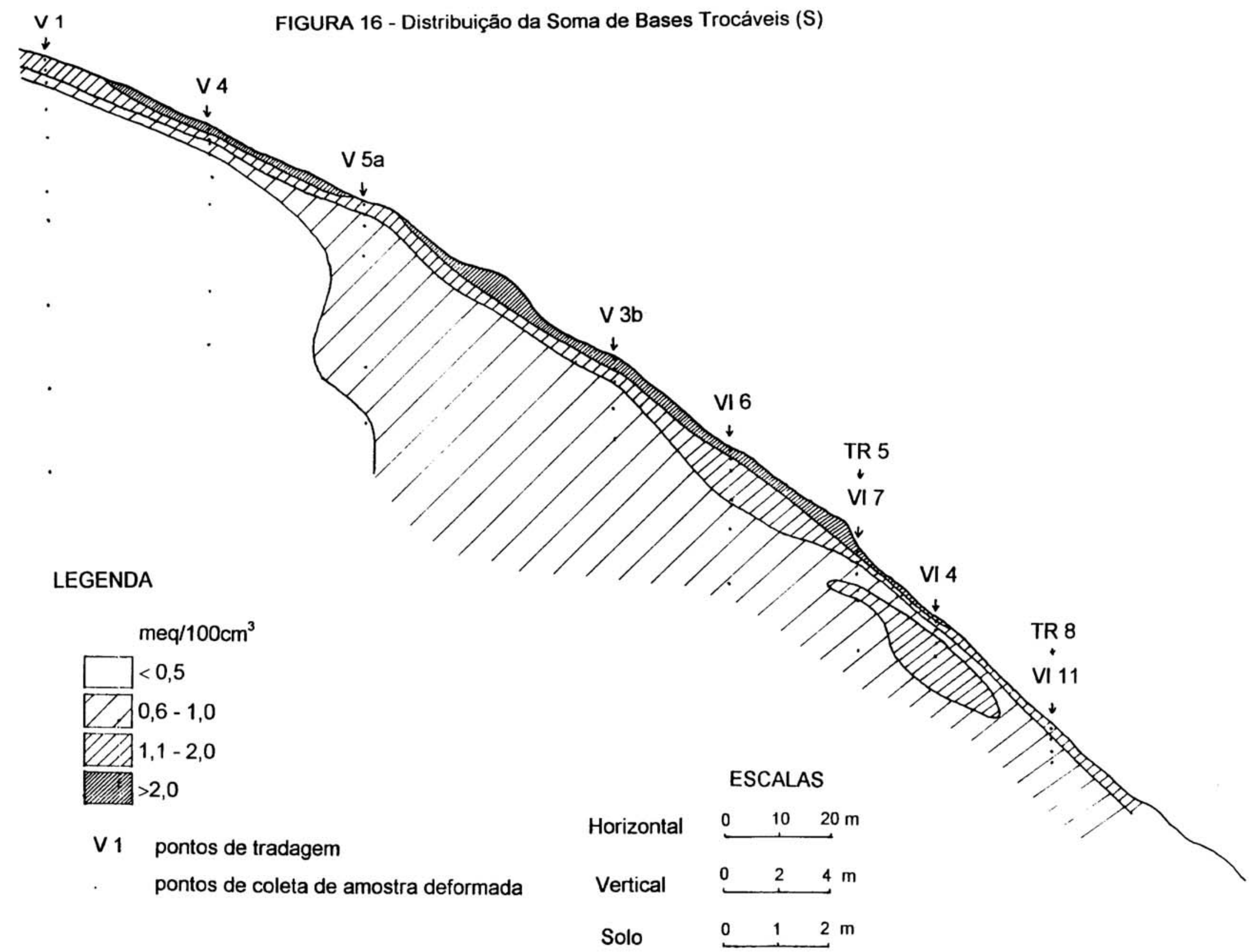


\begin{tabular}{ll}
$\vee 1$ & FIGURA 17 - Distribuição da Capacidade de Troca de Cátions $(T)$ \\
\hline
\end{tabular}

\section{LEGENDA}

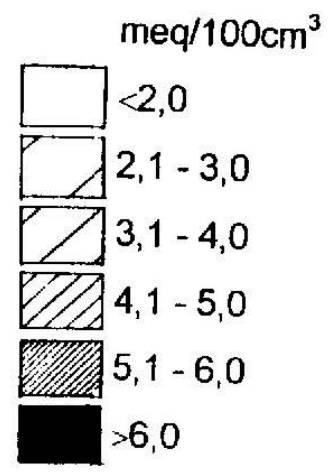

$\checkmark 1$ pontos de tradagem

pontos de coleta de amostra deformada

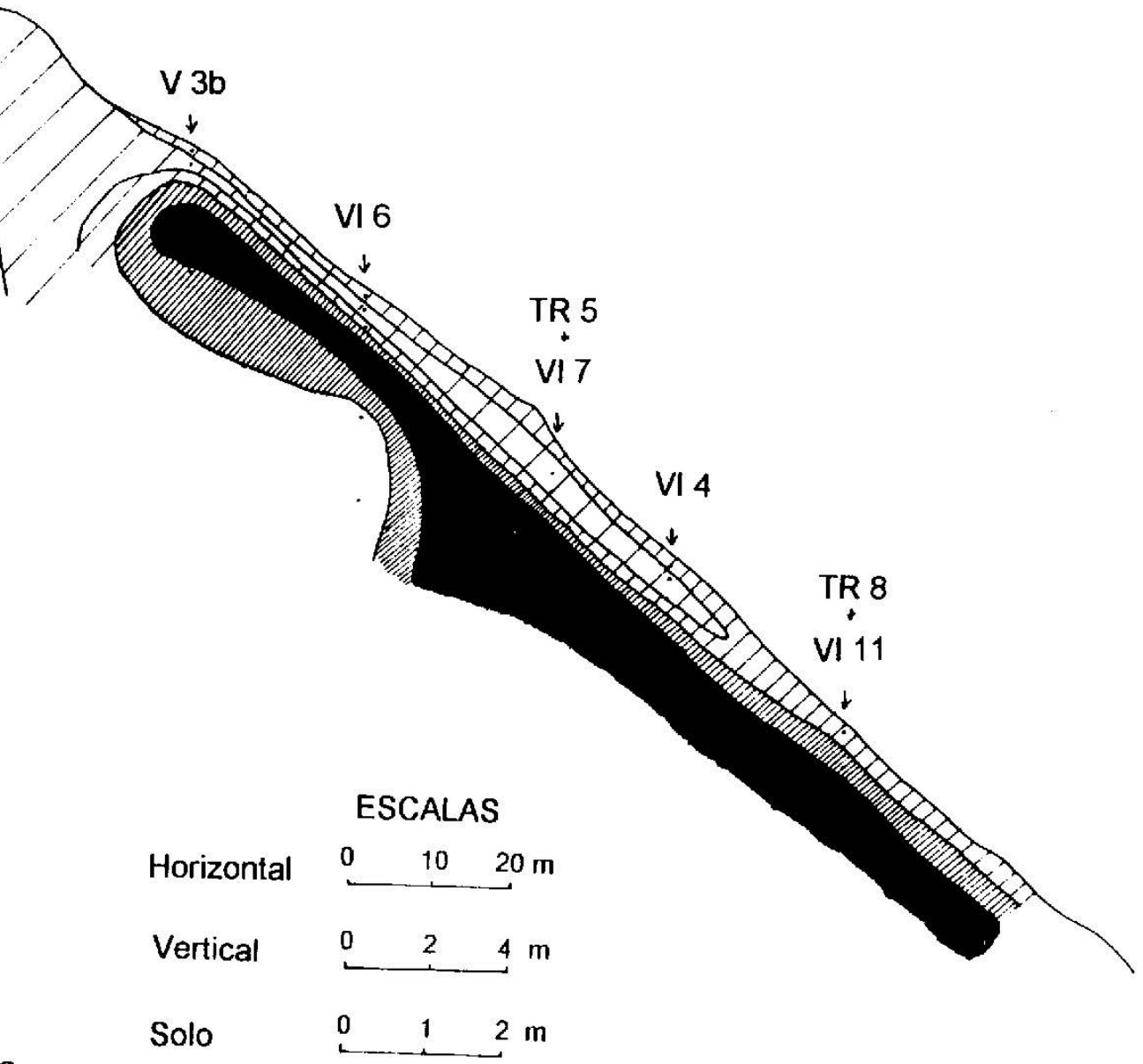




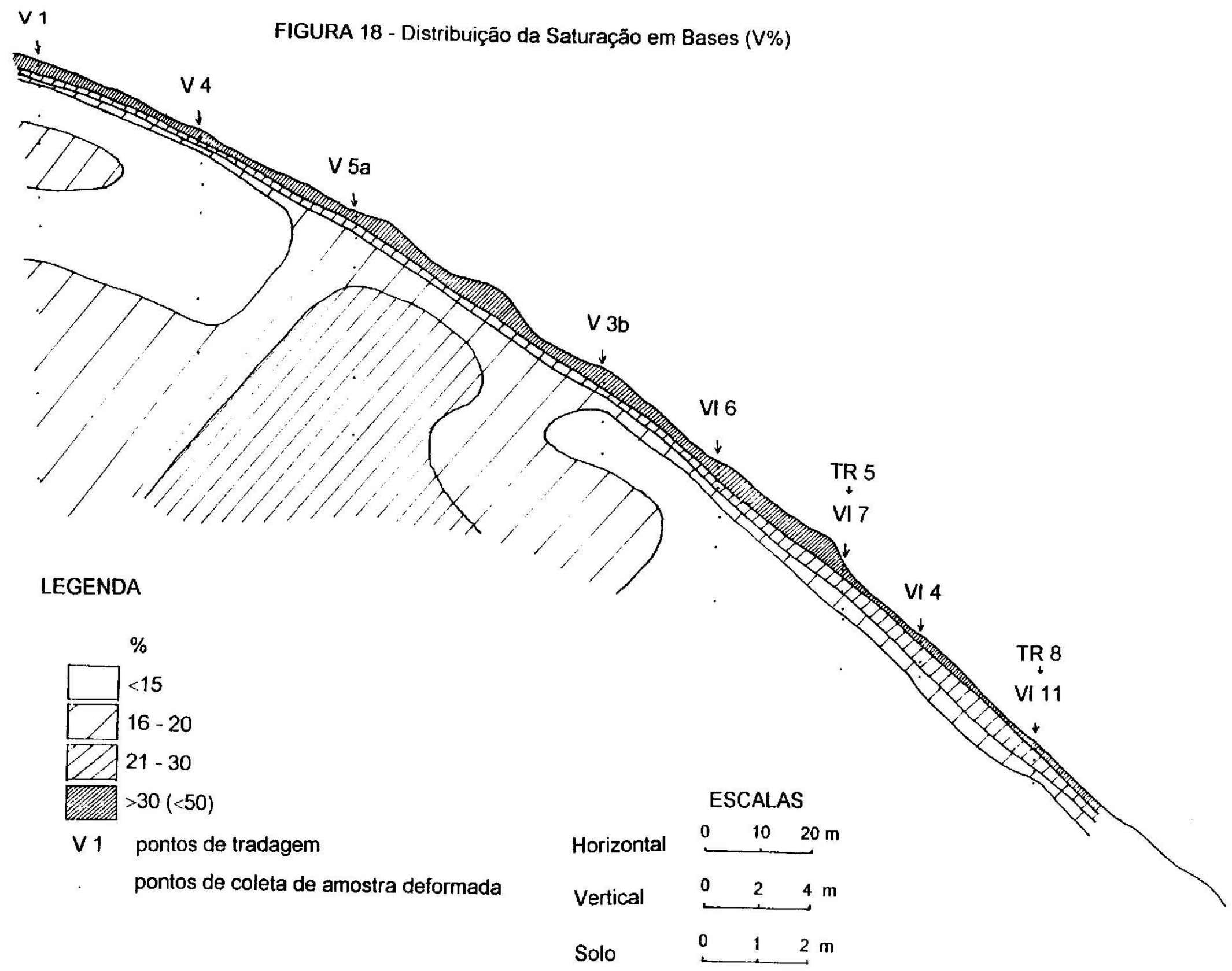


$\mathrm{O}$ índice $\mathrm{Ki}$ mostra teores muito altos maiores que 3,5 no topo da Areia Quartzosa com bandas onduladas da montante, no trecho onde os horizontes $E$ e Bt aparecem hidromorfizados e na alterita do arenito, que é o trecho menos intemperizado da vertente (FIGURA 19). Esses teores são excessivamente altos considerando-se a Capacidade de Troca de Cátions ( $\mathrm{T}), \mathrm{o} \mathrm{pH}$ etc. Contudo, pode ter havido ataque de primários parcialmente intemperizados ou ainda erro de laboratório.

A partir destes resultados pode-se concluir que os solos da Topossequência Retiro I são ácidos, distróficos e álicos, conforme as características exposta por PRADO (1991).

Não se percebe, pelas FIGURAS 16 a 18, nenhuma distribuição em discordância com a morfologia da vertente e dos solos, em particular com a posição dos horizontes na topossequência e com suas texturas, o que corrobora com a idéia de que a mobilidade mais importante é a física (mecânica) e não química dos constituintes.

De forma geral, estes dados concordam com os dados apresentados por BRASIL (1960) e expostos no QUADRO 2 em relação aos baixos valores de pH, $\mathrm{S}$ e $\mathrm{T}$, mas são discordantes quanto aos teores de $\mathrm{V} \%$ e os valores de $\mathrm{Ki}$ encontrados pelos autores, que encontram-se de 60 a $80 \%$ no horizonte $\mathrm{B}$ e em torno de 1,3 a 1,93 , respectivamente.

A posição geomorfológica em que se encontram esses solos e particularmente por se tratar de solos transicionais é que justificaria tais diferenças. Não se trata portanto de Areias Quartzosas típicas e nem tampouco de Podzólicos desenvolvidos. 


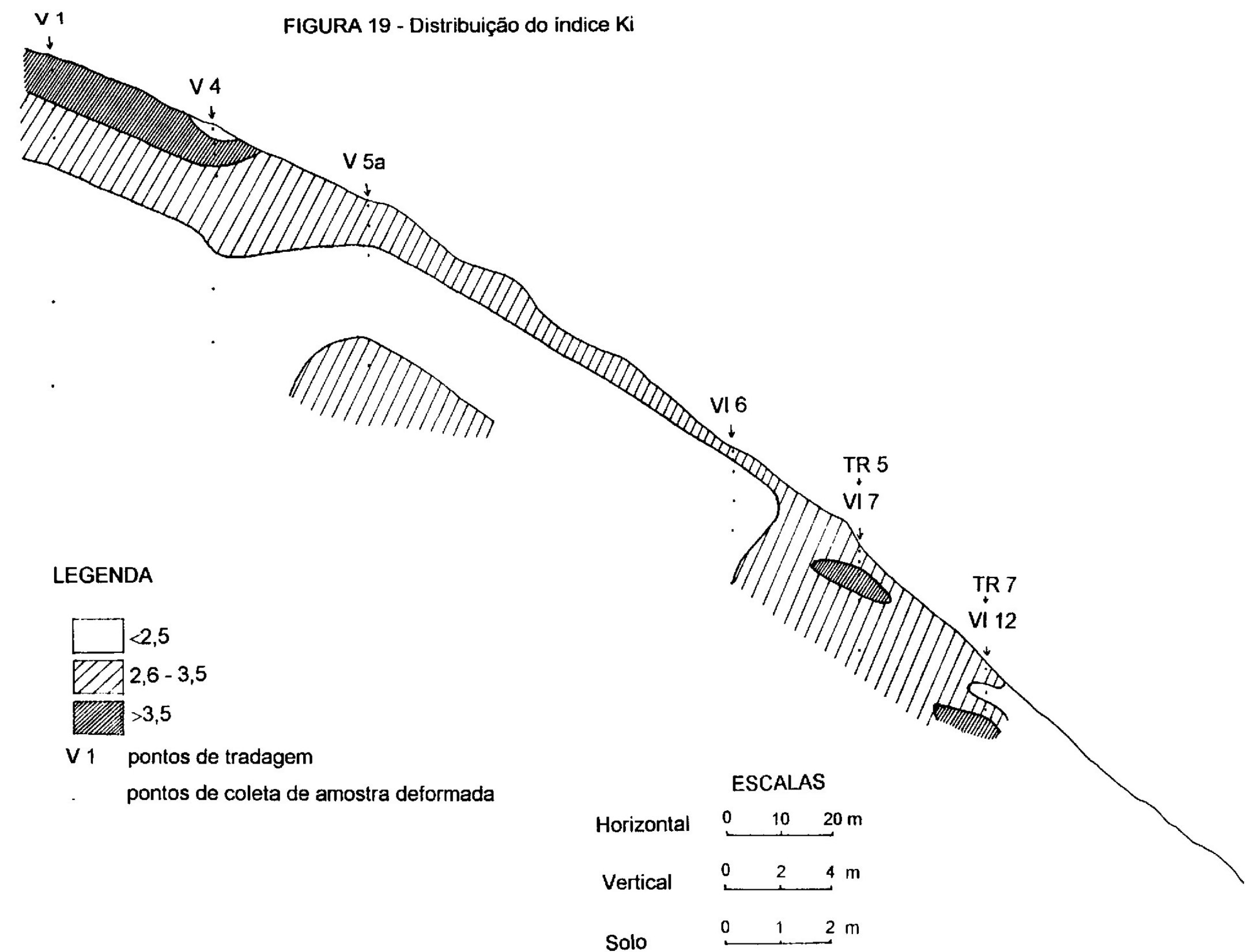




\section{4- INTERPRETAÇÕES E CONSIDERAÇÕES FINAIS}

A transformação das Areias Quartzosas em Areias Quartzosas intermediárias para Podzólico Vermelho-Amarelo e destes para Podzólico Vermelho-Amarelo se dá por processos pedogenéticos de translocação de argila.

Para que as argilas migrem é necessário que haja condições específicas de umidade (água circulante), porosidade (funcional) e do meio (dispersante e floculante com baixo grau de complexação). Essas condições são importantes em ambientes úmidos com solos porosos e que contenham argilas (caulinitas), ainda que em pequenas quantidades e com baixos teores de ferro, como é o caso das Areias Quartzosas da região de São Pedro.

A dissociação plasma/esqueleto resulta na migração da argila seguida da sua acumulação vertical e lateral e numa concentração residual do esqueleto, que progressivamente torna-se mais e mais lavado, à medida que a argila migra.

A presença de cutãs orientados formando pontes entre os grãos, preenchendo poros ou envolvendo grãos, além da cerosidade em campo são as feições que testemunham a translocação da argila.

Tais feições foram encontradas tanto em campo como nas lâminas delgadas, de modo que se trata de um processo de e-iluviação, tanto nas Areias Quartzosas como no Podzólico (não hidromórfico), representativos dos segmentos superior e médio da vertente.

No sistema e-iluvial observa-se que a separação do esqueleto e do plasma caulinítico-ferruginoso, influenciada pela circulação hídrica, promove a exportação do plasma em profundidade e no rumo jusante, onde se acumula. Isso faz com que a drenagem interna se torne cada vez mais interrompida para jusante pela diminuição da porosidade e aumento do plasma e também acarrete mudanças na estrutura, que passa de maciça muito friável nas Areias Quartzosas a poliédrica no Bt pela expansão/retração dos materiais. A presença de quantidades consideráveis de areia (maiores que $75 \%$ ) é também um importante indicador de uma porosidade funcional que irá auxiliar na 
translocação das argilas, mesmo que em pequenas quantidades (menores que $15 \%$ nas Areias Quartzosas).

A formação das bandas onduladas no interior das Areias Quartzosas é facilitada pela ação da gravidade e peneiramento na porosidade de empilhamento, através do fluxo de água, que carrega partículas em suspensão formando uma banda incipiente, que acaba sendo uma barreira para o movimento da água descendente, dado o entupimento dos poros de baixo para cima, conforme o já assinalado por DIJKERMAN et al (1967). Isto acarreta translocações sucessivas ao longo do perfil, graças às condições de clima tropical com estações alternadas presentes na área.

Nos perfis de Areias Quartzosas intermediárias para Podzólico VermelhoAmarelo, as bandas do topo podem ter se formado antes das bandas da base, dada sua estrutura mais desenvolvida (poliédrica) observada em campo e maior contraste em relação aos volumes interbandas do topo do perfil, que aparecem mais lixiviados devido a dissociação plasma/esqueleto e menos lixiviados e contrastados com as bandas da base, caso semelhante estudado por ROLIM NETO \& SANTOS (inédito). Além disso, há uma diferença micromorfológica significativa entre os cutãs do topo das bandas e os cutãs da base. Na parte superior das bandas os cutãs aparecem orientados e preservados, mas na base estes aparecem bastante fragmentados, na forma de pápulas isoladas, reforçando a idéia de formação no topo e degradação na base, no contato com o material interbandas.

Para jusante, observou-se que os cutãs que aparecem no Bt são semelhantes aos encontrados nas bandas onduladas, exceção feita ao Btg (trecho final do Bt) que apresenta cutãs originando fragmentos na porosidade e com perda de ferro, dada sua coloração mais clara devido a sua degradação pela hidromorfia. Assim, nesses casos, a iluviação é mais importante do que a eluviação na formação das bandas onduladas e do Bt na presente área de estudo.

A maior importância da ação da mobilidade física dos constituintes foi reforçada pelos resultados das análises químicas, que ressaltaram uma distribuição 
química concordante de modo geral com a distribuição dos horizontes e suas texturas ao longo da topossequência, também de acordo com os resultados obtidos por BRASIL(1960) e DEMATTÊ et al (1977) na área. Embora os resultados não sejam idênticos aos desses autores, os valores apontam para aumentos ou diminuições a grosso modo semelhantes aos apontados por eles. Dadas as características citadas de e-iluviação, o sistema pedológico estudado é um sistema de transformação com transferência vertical e lateral interna de matéria, consequência das condições climáticas mais úmidas atuais (BOULET et al, 1984).

Portanto, a Topossequência Retiro I corresponde ao sistema pedológico da borda montante do interflúvio Ribeirão do Meio/Samambaia e mostra-se ainda em atividade de transformação pedológica lateral das $A Q$ com bandas onduladas em PV pouco desenvolvido e sua substituição por perfis Li.

Os segmentos superior e médio da topossequência constituem um sistema de transformação pedológica ligado à gênese das bandas onduladas e do Bt da transição glacis-zona dissecada. Já no segmento inferior, a ausência de cutãs e orientações plásmicas e presença de minerais primários (micas) ainda preservados marcaria o início de um novo sistema pedológico de jusante, ligado à formação do Litossolo da zona dissecada. A passagem entre esses dois sistemas é marcada pelo forte aumento da declividade, que passa de $14 \%$ à montante a $20 \%$ para jusante até o Córrego do Retiro, o que reforça o desequilíbrio dos solos do glacis e o equilíbrio dos solos da zona dissecada em relação às condições climáticas atuais. 


\section{5- REFERÊNCIAS BIBLIOGRÁFICAS}

Ab'SABER, A. A. (1969) "A Depressão Periférica Paulista: um setor de circundesnudação pós-cretácica na Bacia do Paraná". São Paulo, IGEOG/USP, 15p. (Geomorfologia 15).

ALARSA, C. (1994) "Estudo das associações entre as formas de relevo e os solos do interflúvio dos ribeirões Samambaia e Araquá na região de Águas de São Pedro-SP". São Paulo, (Trabalho de Graduação Individual) - Depto. de Geografia-FFLCH-USP.

ALMEIDA, F. F. M. de (1964) "Fundamentos geológicos do relevo paulista. Geologia do Estado de São Paulo". São Paulo, Instituto Geográfico e Geológico, (41):167-263.

ALMEIDA, F. F. M. de \& BARBOSA, O. (1953) "Geologia das quadrículas de Piracicaba e Rio Claro". Bol. Div. Geol. Min., Rio de Janeiro, DNPM, (1943):1-96.

BARRETO, M. M. R. (1970) "Geomorfologia da área de São Pedro (SP)". Campinas, Notícia Geomorfológica, 10(19): 47-61.

BOCQUIER, G. (1973) "'Genése et évolution de deux toposéquences de sols tropicaux du Tchad. Mem, ORSTOM, nº 62.

BOND, W. J. (1986) Illuvial band formation in a laboratory column of sand. Soil Sci. Soc. Am. J., Madison, 50(2): 265-267.

BÓSIO, N. J. (1972) "A formação Botucatu na região de São Pedro, SP" IN XXVI Congresso Brasileiro de Geologia (vol. 1), Belém, p. 249-250.

BÓSıO, N. J. (1973) "Geologia da área de São Pedro - SP", Rio Claro (TeseDoutorado), FFLC-UNESP.

BOULET, R. (1974) "Toposéquence de sols tropicaux en Haute Volta. Équilibre et déséquilibre pedobioclimatique. France, 272p. (Tese-Doutorado), Univ. Strasbourg. 
BOULET, R. (1977) "Aperçu sur le milieu pédologique guyanais. Caractères originaux et conséquences sur la mise en valeur." ORSTOM. Cayenne, Cote p.149, Ronéo 36p.

BOULET, R.; CHAUVEL, A.; HUMBEL, F. X. \& LUCAS, Y. (1982) "Analyse structurale et cartographie en Pédologie. I - Prise en compte de l'organisation bidimensionnalle de la couverture pédologique: les études de toposéquences et leurs principaux apport à la connaisance des sols". Cah. ORSTOM Série Pédologie, Vol. XIX, nº 4, p. 309-322.

BOULET, R.; HUMBEL. F. X.\& LUCAS. Y. (1982) "Analyse structurale et cartografie en Pédologie. II - Une méthode d'analyse prenant en compte l'organisation tridimensionnelle des couvertures pédologiques". Cah. ORSTOM Série Pédologie, Vol. XIX, n ${ }^{\circ}$, p. 323-340.

BOULET, R.; HUMBEL, F. X. \& LUCAS Y. (1982) "Analyse structurale et cartographie en Pédologie. III - Passage de la analytique à une cartographie génerale synthétique". Cah. ORSTOM Série Pédologie, Vol. XIX, n 4, p. 341-352.

BOULET, R.; CHAUVEL, A. \& LUCAS, Y. (1984) "Les systemes de transformation en pédologie" AFES, Livre Jubilaire du Cinquantenaire, $p$. 167-179.

BRASIL (1960) "Levantamento de solos do Estado de São Paulo - contribuição à Carta de solos do Brasil" (Boletim 12), SNPA-Comissão de Solos, Rio de Janeiro, Brasil, 350p.

BREWER, R. (1964) "Fabric and mineral analysis of soils" New York, Willy, 470p.

CAMARGO, M. N.; MONIZ, A. C.; JORGE, J. A. \& VALADARES; J. M. A. S. (1986) "Métodos de análise química, mineralógica e física dos solos do Instituto Agronômico do Estado de São Paulo". Campinas, IAC, 94p. (Boletim Técnico 106) 
CAPELLARI, B. (1996) "Estudo das áreas de risco à erosão em São Pedro, SP." São Paulo. (Trabalho de Graduação Individual), Departamento de GeografiaFFLCH-USP.

CARVALHO, A.; CHAUVEL, A.\& GONÇALVES, N. M. M. (1983) "Alteration of basalt and formation of kaolinic and gibbsitic material in the region of Ribeirão Preto (SP), Brazil". In: Intern. Sem. On Later., 2, São Paulo, Proceedings, p. 477-489.

CASTRO, S. S. de (1985) "Impregnação de amostras de solo para confecção de lâmina delgada". Sociedade Brasileira de Ciência do Solo - Boletim Informativo, Campinas, 44p.

CASTRO, S. S. de (1989) "Sistemas de transformação pedológica em Marília: B latossólicos e B texturais" São Paulo, 274p. (Tese - Doutorado), Departamento de Geografia-FFLCH-USP.

CASTRO, S. S. de (1989) "Micromorfologia de solos - pequeno guia para descrição de lâminas delgadas" São Paulo, DG-USP/IPT, 87p.

CASTRO, S. S. de \& CURMI, P. (1987) "Bandas onduladas em solos podzolizados - variação Marília: estruturas de transformação pedológica. Resumo e Com. XV Congr. Bras. Ci. Solo, Campinas.

CHAUVEL, A. (1976) "Recherches sur la transformation des sols ferralitiques dans la zone tropicale à saisons contrastées. Trav. et Doc., 62, 532p. (Tese Doutorado), Univérsité de Strasbourg, ORSTOM.

CHAUVEL, A. (1979) "Iniciação à análise microscópica dos solos." ESALQ-USP, Mimeografado. Piracicaba.

CONTI, J. B. (1971) "Condições climáticas da região das Águas de São Pedro (SP)", Caderno de Ciências da Terra, n 11, USP/IG, São Paulo, 15p.

COOPER, M. (1996) "Sequência de solos com B latossólico e B textural em Piracicaba (SP)". Piracicaba, 102p. (Dissertação - Mestrado), ESALQ-USP.

COUTARD, J. P.; DIAS FERREIRA, R. P.; PELLERIN, J. \& QUEIROZ NETO, J. P. (1978) "Excursão à região da Serra de São Pedro e Vale do rio Piracicaba" in: Guia das Excursões vol. II do Colóquio Interdisciplinar 
Franco-Brasileiro: "Estudo e Cartografia de Formações Superficiais e suas aplicações em regiões tropicais", São Paulo, p. 45-74.

CUNHA, J. E. da (1996) "Caracterização morfológica (macro e micro) e comportamento físico-hídrico de duas topossequências em Umuarama (PR): subsídios para avaliação dos processos erosivos." São Paulo, 129p. (Dissertação - Mestrado) Departamento de Geografia-FFLCH-USP.

DEMATTÊ, J. L. I. \& HOLOWAYCHUK, N. (1977) "Solos da região de São Pedro, Estado de São Paulo. I. Propriedades granulométricas e químicas." Revista Bras. de Ciência do Solo, Campinas, 1(2-3), p. 92-98.

DEMATTÉ, J. L. I. \& HOLOWAYCHUK, N. (1977) "Solos da região de São Pedro, Estado de São Paulo. II. Mineralogia." Revista Bras. de Ciência do Solo, Campinas, 1(2-3), p.99-103.

DEMATTÊ, J. L. I.; WILDING, L. P. \& HOLOWAYCHUK, N. (1977) "Solos da região de São Pedro, Estado de São Paulo. III. Micromorfologia." Revista Bras. de Ciência do Solo, Campinas, (1(2-3), p.104-107.

DIAS FERREIRA, R. P. (1977) "Solos e morfogênese em São Pedro-SP." São Paulo, 157p. (Tese - Doutorado), Departamento de Geografia-FFLCH-USP.

DIJKERMAN, J. C.; CLINE, M.G. \& OLSON, G.W. (1967) "Properties and genesis of textural subsoil lamellae. Soil Sci., 104: 7-16.

DRESCH, J. (1962) "Pedimentos, "glacis" de erosão, pediplanícies e inselbergs." Notícia Geomorfológica 9/10, FFCL/Depto. de Geografia. Campinas, p. 1-23.

DUARTE, U. (1980) "Geologia ambiental da área de São Pedro-SP -vetor águas subterrâneas" São Paulo (Tese - Doutorado), Instituto de Geociências-USP.

EMBRAPA (1988) "Sistema brasileiro de classificação de solos $\left(1^{a}\right.$ aproximação), Rio de Janeiro, SNLCS, 107p.

ESWARAN, H. \& SYS, C. (1979) "Argilic horizon in LAC soils: formation and significance to classification. Pedologie, Ghent, 29: 175-190.

FEDOROFF, N. \& ESWARAN, H. (1985) "Micromorphology of Ultisols." In: Soil micromorphology and soil classification. Proceedings of a symposium 
sponsored by divisions S- 5 and S-9 of the Soil Science Society of America. Anaheim. Ed. L. A. Douglas and M. L. Thompson, SSSA. Madison, p. 145164.

FERNANDES BARROS, O. N. (1985) "Análise estrutural e cartografia detalhada dos solos em Marília, Estado de São Paulo: ensaio metodológico". (Dissertação-Mestrado), Departamento de Geografia-FFLCH-USP.

FERNANDES BARROS, O. N. (1996) "Formação de horizontes pedológicos em solos sobre basalto (Londrina-PR, Brasil) e ação biológica no intemperismo". São Paulo, 201p. (Tese - Doutorado) Departamento de GeografiaFFLCHUSP.

FILIZOLA, H. F. (1994) "O papel da erosão geoquímica na evolução do modelado na bacia de Taubaté/SP". São Paulo, 114p. (Tese - Doutorado), Departamento de Geografia-FFLCH-USP.

IPT (1981) "Mapa Geológico do Estado de São Paulo", Série Monografias n 6, 2 Vol., São Paulo, IPT, 126p.

IPT (1981) "Mapa Geomorfológico do Estado de São Paulo" Série Monografias $\mathrm{n}^{\circ} 5$, 2 Vol., São Paulo, IPT, 94p.

KEMP, R. A. \& McINTOSH, P. D. (1989) "Genesis of texturally banded soil in Southland, New Zealand". Geoderma. Amsterdam, 45(1): 65-81.

KERTZMAN, F. F. (1996) "Modificação na estrutura e no comportamento de um latossolo roxo provocadas pela compactação". São Paulo, 173p. (Tese doutorado) Depto. de Geografia-FFLCH-USP.

LADEIRA, F. S. B. (1995) "Estudo micromorfológico de um latossolo roxo no município de Guaíra-SP". São Paulo, 143p. (Dissertação - Mestrado) Depto. de Geografia-FFLCH-USP.

LEMOS, R. C. \& SANTOS, R. D. (1982) "Manual de descrição e coleta de solo no campo", Campinas, SBCS, 45p.

LUCAS, Y.; CHAUVEL, A.; BOULET, R. RANZANI, G. \& SCATOLINI, F. (1984) "Transição latossolos-podzóis sobre a formação Barreiras na região de Manaus". Revista Bras. Ci. Solo, 8, p. 325-335. 
MELO, M. S. \& PONÇANO, W. L. (1983) "Gênese, distribuição e estratigrafia dos depósitos cenozóicos no Estado de São Paulo“. IPT, São Paulo, Série Monografias 9, 74p.

MONIZ, A. C. (1972) "Elementos de pedologia", São Paulo, Edusp/Polígono, 459p.

MONIZ, A. C. (1980) "Formation of na oxisol-ultisol transition in São Paulo, Brazil". (Tese - Doutorado) Department of Soil Science, Raleigh, 290p.

NAKASATO, E. T. (1992) "Caracterização morfológica da Bacia do Ribeirão do Meio - município de São Pedro-SP. Primeira aproximação com apoio na análise de fotografias aéreas". São Paulo, 75p. (Trabalho de Graduação Individual), Departamento de GeografiaFFLCH-USP.

NASCIMENTO, N. R. (1993) "Sistemas de transformação pedológica solos lateríticos com couraça ferruginosa em silcrete e/ou planossolo: aplicação à cartografia da pedomorfologia do médio vale do Paramirim-BA." São Paulo. (Tese - Doutorado), Instituto de Geociências-USP.

NETTLETON, W. D.; FLACH, K. W. \& BRASHER, B. R. (1969) "Argillic horizons without clay skins." Soil Science Society America Proceedings, 33:121-125.

NICOLA, S. M. C. (1993) "Sistemas pedológicos desenvolvidos sobre basalto na região de llha Solteira (estado de São Paulo-Brasil): gênese e transformação". 2 vol. São Paulo. (Tese de Doutorado), Instituto de Geociências-USP.

OLIVEIRA, E. P. de (1930) "Nota sobre os arenitos de Botucatu e Pirambóia." Bol. Serv. Geol. Min., Rio de Janeiro, (46): 50-54.

OLIVEIRA, D. de (1992) "Estudo da origem dos materiais dos solos da cobertura arenosa do glacis de São Pedro, em São Pedro, SP". São Paulo, 75 p. (Trabalho de Graduação Individual), Departamento de Geografia-FFLCHUSP.

OLIVEIRA, J. B. \& PRADO, H. (1989) "Carta pedológica semi-detalhada do Estado de São Paulo - folha Piracicaba”. Campinas, IAC, (escala 1:100.000). 
OLIVEIRA, J. B. \& van den BERG, M. (1992) "Application of the soter methodology to a semi-detailed survey $(1: 100,000)$ in the Piracicaba region". ISRIC, SOTER, 28p.

OLIVEIRA, J. B.; JACOMINE, P. K. T. \& CAMARGO, M. N. (1992) "Classes gerais de solos do Brasil", Jaboticabal/UNESP, Funep, 201p.

OLIVEIRA, D. de; CASTRO, S. S de \& DIAS FERREIRA, R. P. (1994) "Contribuição ao estudo do material de origem da cobertura arenosa de São Pedro, SP" São Paulo, Boletim Paulista de Geografia $n^{\circ} 73$, AGB (Associação de Geógrafos Brasileiros) , p.149-164.

OLIVEIRA, J. B. \& MENK, J. R. F. (no prelo) "Levantamento semi-detalhado de solos - folha Piracicaba", Campinas, Boletim do Instituto Agronômico de Campinas (IAC).

PACHECO, J. A. de A. (1927) "Relatório elucidativo do esboço geológico da região compreendida entre o meridiano $4^{\circ}$ Rio Itararé e os paralelos $23^{\circ} 34^{\prime}$ e $24^{\circ} 38^{\prime}$." In: Exploração da região compreendida pelas folhas topográficas de Sorocaba, Itapetininga, Bury, Itaporanga, Sete Barras, Capão Bonito, Ribeirão Branco e Itararé. São Paulo, Com. Geogr. Geol., p. 9-12.

PENTEADO, M. M. (1970) "Características dos pedimentos nas regiões quentes e úmidas." Notícia Geomorfológica, Campinas, 10(19): 3-16.

PENTEADO, M.M. (1974) "Fundamentos de Geomorfologia." IBGE, Rio de Janeiro, 158p.

PRADO, H. (1991) "Manejo dos solos - Descrições pedológicas e suas implicações". São Paulo, Nobel, 116p.

PRADO, H. (1995) "Manual de classificação de solos do Brasil." $2^{a}$ ed., Jaboticabal, FINEP, 197p.

QUEIROZ NETO, J. P. (1975) "Observações preliminares sobre perfis de solos com bandas onduladas do Estado de São Paulo." Sedimentologia e Pedologia, 7, IG/USP, São Paulo, 32p.

QUEIROZ NETO, J. P. \& JOURNAUX, A. (1978) "Carta geomorfológica de São Pedro-SP - Memorial Explicativo" IG-USP, São Paulo, (escala 1:50.000). 
ROLIM NETO, F. C. \& SANTOS, M. C. D. (inédito) "Gênese de solos arenoso com lamelas no agreste de Pernambuco."

RUELLAN, A. (1970) "Contribuition a la connaissance de sols des régions mediterranéennes: les sols a profil calcaire différencié des Plaines de la Basse Moulouya (Maroc Oriental), enregistrement au CNRS, 482p. (mimeografado)

RUELLAN, A. (1984-85) "Les sols dans le paysage" Célébration du Cinquantenaire de l'AFES, Cah. ORSTOM, sér. Pédol., vol. XXI, $n^{\text {os }} 213$, p. 133-217.

RUELLAN, A.; DOSSO, M, \& FRITSCH, E. (1989) "L'analyse structurale de la couverture pédologique" Science du Sol, vol. 27, p. 319-334.

RUELLAN, A. \& DOSSO, M. (1993) "Regards sur le sol." Universités Francophones. Édicion Soucher, Paris, 192p.

SALOMÃO, F. X. T. (1994) "Processos erosivos lineares em Bauru, SP: regionalização cartográfica aplicada ao controle preventivo urbano e rural." São Paulo, São Paulo, 200p. (Tese - Doutorado), Departamento de GeografiaFFLCHUSP.

SANTOS, L. J. C. (1995) "Estudo morfológico da Topossequência da Pousada da Esperança, em Bauru, SP: subsídio para a compreensão da gênese, evolução e comportamento atual dos solos. São Paulo, 2 vol. São Paulo, 71 p. (Dissertação-Mestrado), Departamento de Geografia-FFLCH-USP.

SETZER, J. (1949) "Solos do Estado de São Paulo." Rio de Janeiro, IBGE.

SOARES, P. C. (1973) "O mezosóico gondwânico no estado de São Paulo". Rio Claro, 152 p. (Tese-Doutorado), FFLC-UNESP.

SOKOLONSKI, H. H. (1985) "Caracterização e evolução pedogenética de alguns latossolos do vale do Paramirim (Bahia)." Bahia. (Dissertação Mestrado) IG/UFBA.

SOUBIĖS, F.; SOKOLONSKI, H.H. \& AUDRY, P. (1983) "Evolução pedológica e geoquímica das formações superficiais do vale do Paramirim-Bahia." Brasília, CNPq, (relatório), 16p. 
SOUBIĖS, F. \& CHAUVEL, A. (1984-1985) "Présentation de quelques systèmes de sols observès au Brésil” Cah. ORSTOM Série Pédologie, vol. XIX, n 4, p. 237-251.

STOOPS, G. \& JONGERIUS, A. (1975) "Proposal for micromorphological classification in soil materials. I. A classification of related distribuitions of coarse and fine particles". Geoderma, Amsterdam, 13:p.189-200. (a reply Geoderma, 19, p.247-249, 1977).

SUGUIO. K. \& COIMBRA, A. M. "Estudo sedimentológico das "bandas onduladas" de solos da formação Bauru na área balisada pelas cidades de Osvaldo Cruz - Rancharia e Tupã, Estado de São Paulo". Boletim do Instituto de Geociências. IG-USP. São Paulo, 7: 27-38.

TRICART, J.; RAYNAL, R. \& BESANÇON, J. (1972) "Cônes rocheux, pédiments, glacis." Annales de Géographie, 443, LXXXI année, p. 1-24.

VIDAL TORRADO, P. (1994) "Pedogênese e morfogênese no distrito de Tupi (Piracicaba-SP)". Piracicaba, 212 p. (Tese-Doutorado), ESALQ-USP.

WU, F. T. \& SOARES, P. C. (1974) "Minerais pesados nas formações Pirambóia e Botucatu", XXVIII Congresso Brasileiro de Geologia, Porto Alegre, vol. 2, p. 119-127. 


\section{ANEXO I}

QUADRO 4 - Resultados da análise granulométrica ${ }^{1}$

\begin{tabular}{|c|c|c|c|c|c|c|c|}
\hline \multirow{16}{*}{$\begin{array}{l}\text { trinc./trad. } \\
\text { SPFR } 14\end{array}$} & prof. $\mathrm{cm}$ & argila \% & silte fino & silte grosso & areia fina & areia grossa & TOTAL \\
\hline & $0-30$ & 4.3 & 0.2 & 0.9 & 72.7 & 20.5 & 98.7 \\
\hline & $0-30$ & 4.3 & 0.8 & 1.1 & 74.4 & 18.7 & 99.3 \\
\hline & $30-90$ & 7.1 & 1.2 & 1.5 & 67.6 & 21.8 & 99.3 \\
\hline & $30-90$ & 8.6 & 1.3 & 1.7 & 69.6 & 18.4 & 99.7 \\
\hline & $30-90$ & 8.5 & 1.0 & 1.5 & 67.6 & 21.2 & 99.9 \\
\hline & $90-125$ & 14.1 & 0.7 & 1.6 & 65.5 & 17.9 & 99.8 \\
\hline & $90-125$ & 9.7 & 1.2 & 1.6 & 66.8 & 21.0 & 100.4 \\
\hline & $125-160$ & 12.2 & 0.9 & 2.0 & 66.4 & 18.1 & 99.6 \\
\hline & $125-160$ & 15.5 & 0.7 & 1.6 & 64.5 & 16.9 & 99.3 \\
\hline & $125-160$ & 10.9 & 0.6 & 1.8 & 68.8 & 17.4 & 99.6 \\
\hline & $125-210$ & 15.9 & 0.8 & 1.6 & 60.8 & 20.2 & 99.5 \\
\hline & $125-210$ & 12.7 & 1.8 & 1.8 & 66.0 & 17.8 & 100.2 \\
\hline & $125-210$ & 14.8 & 1.2 & 2.0 & 64.2 & 17.8 & 100.0 \\
\hline & $125-160$ & 13.2 & 0.3 & 1.7 & 66.5 & 18.2 & 100.0 \\
\hline & $125-160$ & 13.0 & 0.2 & 2.0 & 68.3 & 16.4 & 100.0 \\
\hline \multirow[t]{15}{*}{ SPFR 8} & $0-45$ & 6.0 & 0.0 & 1.4 & 75.1 & 15.3 & 97.8 \\
\hline & $0-45$ & 9.3 & 0.5 & 1.6 & 69.6 & 16.9 & 97.9 \\
\hline & $0-45$ & 11.4 & 0.3 & 1.6 & 68.7 & 16.3 & 98.4 \\
\hline & $45-70$ & 15.1 & 0.0 & 1.7 & 65.0 & 16.8 & 98.6 \\
\hline & $45-70$ & 12.8 & 0.5 & 1.7 & 67.7 & 15.7 & 98.4 \\
\hline & $70-97$ & 17.5 & 0.3 & 1.6 & 64.4 & 14.8 & 98.6 \\
\hline & $70-97$ & 14.3 & 0.1 & 1.6 & 66.8 & 16.0 & 98.9 \\
\hline & $97-153$ & 13.3 & 0.4 & 1.6 & 66.7 & 16.8 & 98.9 \\
\hline & $97-153$ & 19.0 & 0.6 & 1.6 & 61.7 & 16.3 & 99.2 \\
\hline & $153-220$ & 13.7 & 0.8 & 1.9 & 66.5 & 16.4 & 99.4 \\
\hline & $153-220$ & 17.9 & 0.5 & 1.8 & 64.1 & 14.8 & 99.1 \\
\hline & $153-220$ & 14.8 & 0.4 & 1.9 & 67.6 & 14.7 & 99.5 \\
\hline & $153-220$ & 18.5 & 0.5 & 1.8 & 64.3 & 14.6 & 99.8 \\
\hline & $153-220$ & 14.2 & 0.5 & 1.8 & 65.1 & 17.3 & 99.1 \\
\hline & $153-220$ & 14.2 & 0.5 & 1.8 & 66.3 & 16.7 & 99.6 \\
\hline \multirow[t]{11}{*}{ Trincheira 1} & $0-10$ & 5.7 & 1.3 & 1.8 & 75.6 & 13.9 & 98.5 \\
\hline & 35 & 8.5 & 1.1 & 2.3 & 72.0 & 15.0 & 99.0 \\
\hline & 45 & 21.1 & 0.8 & 2.2 & 63.1 & 11.4 & 98.7 \\
\hline & 65 & 24.1 & 1.4 & 2.4 & 59.3 & 12.1 & 99.3 \\
\hline & 80 & 24.9 & 0.9 & 2.5 & 58.6 & 12.1 & 99.0 \\
\hline & 95 & 21.2 & 1.4 & 2.4 & 62.0 & 12.5 & 99.5 \\
\hline & 125 & 17.0 & 3.5 & 1.9 & 63.5 & 14.1 & 100.0 \\
\hline & 140 & 15.8 & 4.8 & 2.0 & 66.1 & 11.6 & 100.3 \\
\hline & 155 & 13.7 & 6.6 & 1.6 & 61.8 & 16.5 & 100.2 \\
\hline & 35 & 19.7 & 0.3 & 2.6 & 65.4 & 10.9 & 99.0 \\
\hline & 60 & 24.3 & 0.9 & 2.2 & 60.1 & 11.9 & 99.4 \\
\hline
\end{tabular}

${ }^{1}$ Análises realizadas no Centro da ORSTOM - Cayena. 


\begin{tabular}{|c|c|c|c|c|c|c|c|}
\hline |Trincheira 2 & $\begin{array}{l}60 \\
80\end{array}$ & $\begin{array}{l}19.5 \\
23.6\end{array}$ & $\begin{array}{l}0.6 \\
1.6\end{array}$ & $\begin{array}{l}2.4 \\
2.4\end{array}$ & $\begin{array}{l}64.6 \\
60.2\end{array}$ & $\begin{array}{l}11.7 \\
11.6\end{array}$ & $\begin{array}{l}98.9 \\
99.5\end{array}$ \\
\hline \multirow[t]{18}{*}{ TRAD. V-1 } & $0-10$ & 4.4 & 0.9 & 1.3 & 71.5 & 20.7 & 98.9 \\
\hline & $20-30$ & 5.8 & 1.0 & 1.2 & 72.6 & 18.2 & 99.0 \\
\hline & $40-50$ & 9.6 & 0.7 & 1.6 & 69.5 & 17.4 & 98.8 \\
\hline & $90-100$ & 12.0 & 0.2 & 1.8 & 68.9 & 16.7 & 99.5 \\
\hline & $140-150$ & 11.0 & 0.8 & 1.5 & 66.1 & 20.1 & 99.6 \\
\hline & $190-200$ & 11.4 & 1.3 & 1.6 & 66.1 & 19.1 & 99.6 \\
\hline & $240-250$ & 10.9 & 0.7 & 1.6 & 67.6 & 18.9 & 99.7 \\
\hline & $290-300$ & 11.6 & 0.8 & 1.7 & 68.8 & 17.2 & 100.1 \\
\hline & $340-350$ & 13.1 & 0.8 & 1.8 & 68.3 & 16.3 & 100.3 \\
\hline & $390-400$ & 13.4 & 0.4 & 1.8 & 65.7 & 19.0 & 100.3 \\
\hline & $440-450$ & 14.2 & 0.4 & 2.1 & 66.4 & 16.7 & 99.8 \\
\hline & $490-500$ & 14.4 & 0.3 & 1.8 & 65.0 & 18.4 & 99.9 \\
\hline & $540-550$ & 14.3 & 0.4 & 2.0 & 66.2 & 17.2 & 100.1 \\
\hline & $590-600$ & 13.8 & 1.2 & 1.7 & 65.9 & 17.9 & 100.5 \\
\hline & $610-650$ & 14.3 & 0.9 & 1.8 & 65.9 & 17.6 & 100.5 \\
\hline & $690-700$ & 14.0 & 0.6 & 1.9 & 66.8 & 16.8 & 100.1 \\
\hline & $740-750$ & 13.2 & 0.8 & 1.7 & 63.1 & 21.4 & 100.2 \\
\hline & $790-800$ & 13.7 & 1.0 & 1.7 & 65.1 & 18.4 & 99.9 \\
\hline \multirow[t]{14}{*}{ TRAD. V-1a } & $0-10$ & 5.1 & 0.6 & 0.9 & 72.0 & 20.2 & 98.8 \\
\hline & $20-30$ & 7.0 & 0.6 & 1.4 & 72.1 & 18.2 & 99.3 \\
\hline & $40-50$ & 8.9 & 0.8 & 1.5 & 67.8 & 19.8 & 98.8 \\
\hline & $90-100$ & 11.3 & 0.5 & 1.6 & 65.3 & 20.9 & 99.6 \\
\hline & $140-150$ & 14.6 & 1.3 & 2.0 & 65.5 & 16.2 & 99.6 \\
\hline & $190-200$ & 11.4 & 0.7 & 1.9 & 69.6 & 15.8 & 99.4 \\
\hline & $240-250$ & 11.0 & 0.4 & 1.6 & 67.9 & 18.7 & 99.6 \\
\hline & $290-300$ & 11.6 & 0.4 & 1.8 & 68.1 & 17.3 & 99.2 \\
\hline & $340-350$ & 12.7 & 0.4 & 1.9 & 66.0 & 18.6 & 99.6 \\
\hline & $390-400$ & 13.4 & 0.2 & 1.9 & 64.7 & 19.1 & 99.3 \\
\hline & $440-450$ & 15.5 & 0.5 & 2.3 & 65.5 & 16.1 & 99.9 \\
\hline & $490-500$ & 13.7 & 1.7 & 2.0 & 64.7 & 18.3 & 100.4 \\
\hline & $540-550$ & 14.2 & 1.9 & 2.2 & 68.1 & 14.5 & 100.9 \\
\hline & $590-600$ & 13.5 & 1.2 & 2.0 & 64.4 & 18.8 & 99.9 \\
\hline \multirow[t]{11}{*}{ TRAD. V-4 } & $0-10$ & 5.0 & 0.6 & 1.1 & 70.2 & 20.9 & 97.8 \\
\hline & $20-30$ & 8.4 & 1.1 & 1.5 & 70.2 & 17.3 & 98.5 \\
\hline & $30-40$ & 8.6 & 1.4 & 1.7 & 70.3 & 16.9 & 98.9 \\
\hline & $40-50$ & 9.7 & 0.2 & 1.8 & 66.9 & 20.3 & 98.9 \\
\hline & $90-100$ & 12.9 & 0.4 & 1.7 & 67.3 & 16.8 & 99.1 \\
\hline & $140-150$ & 13.9 & 1.0 & 1.8 & 64.2 & 18.9 & 99.8 \\
\hline & $190-200$ & 12.0 & 1.2 & 1.9 & 68.8 & 16.0 & 99.9 \\
\hline & $240-250$ & 11.8 & 0.5 & 1.7 & 69.3 & 16.4 & 99.7 \\
\hline & $290-300$ & 12.5 & 0.5 & 1.8 & 69.0 & 15.5 & 99.3 \\
\hline & $340-350$ & 12.3 & 0.3 & 1.9 & 72.2 & 13.0 & 99.7 \\
\hline & $390-400$ & 14.8 & 0.1 & 2.2 & 68.2 & 14.7 & 100.0 \\
\hline \multirow[t]{2}{*}{ TRAD.V-5 } & $0-10$ & 6.4 & 0.1 & 1.2 & 74.3 & 16.6 & 98.6 \\
\hline & $20-30$ & 8.4 & 0.3 & 1.8 & 73.6 & 14.5 & 99.6 \\
\hline
\end{tabular}




\begin{tabular}{|c|c|c|c|c|c|c|c|}
\hline & $40-50$ & 8.8 & 0.7 & 2.2 & 71.9 & 16.0 & 99.6 \\
\hline & $90-100$ & 15.2 & 0.3 & 1.8 & 65.8 & 16.4 & 99.5 \\
\hline & $140-150$ & 17.1 & 0.1 & 1.8 & 64.5 & 15.7 & 99.2 \\
\hline & $190-200$ & 15.5 & 0.1 & 2.0 & 68.7 & 13.1 & 99.4 \\
\hline & $240-250$ & 13.5 & 0.2 & 2.0 & 70.6 & 13.8 & 100.1 \\
\hline & $290-300$ & 14.0 & 0.8 & 2.1 & 69.0 & 14.7 & 100.6 \\
\hline & $340-350$ & 14.7 & 1.4 & 2.2 & 68.1 & 14.2 & 100.6 \\
\hline & $390-400$ & 16.1 & 0.3 & 2.3 & 68.8 & 12.7 & 100.2 \\
\hline TRAD. V-5a & $0-10$ & 5.6 & 0.1 & 1.3 & 76.4 & 15.2 & 98.6 \\
\hline & $20-30$ & 7.0 & 0.5 & 1.5 & 76.2 & 13.9 & 99.1 \\
\hline & $40-50$ & 10.2 & 0.5 & 2.0 & 72.7 & 13.4 & 99.9 \\
\hline & $90-100$ & 12.2 & 0.7 & 2.3 & 70.6 & 13.9 & 99.7 \\
\hline & $140-150$ & 13.0 & 0.3 & 1.9 & 70.8 & 13.7 & 96.7 \\
\hline & $190-200$ & 14.3 & 0.5 & 1.8 & 68.9 & 14.7 & 100.2 \\
\hline & $240-250$ & 13.0 & 1.4 & 2.1 & 70.0 & 13.6 & 100.1 \\
\hline & $290-300$ & 13.3 & 0.6 & 2.3 & 70.2 & 13.3 & 99.7 \\
\hline & $340-350$ & 8.4 & 6.3 & 2.2 & 68.4 & 13.7 & 99.0 \\
\hline & $390-400$ & 16.1 & 1.2 & 2.2 & 67.1 & 13.9 & 100.5 \\
\hline TRAD. V-3a & $0-10$ & 4.8 & 1.5 & 1.4 & 72.8 & 18.3 & 98.8 \\
\hline & $20-30$ & 5.6 & 0.7 & 1.5 & 74.3 & 17.0 & 99.1 \\
\hline & $40-50$ & 9.6 & 1.0 & 1.8 & 71.6 & 15.7 & 99.7 \\
\hline & $90-100$ & 12.8 & 6.2 & 2.4 & 66.8 & 11.2 & 99.4 \\
\hline & $140-150$ & 18.4 & 1.4 & 2.4 & 64.4 & 13.5 & 100.1 \\
\hline & $190-200$ & 17.3 & 1.1 & 2.6 & 66.3 & 12.2 & 99.5 \\
\hline & $240-250$ & 25.5 & 7.2 & 2.8 & 53.1 & 11.6 & 100.2 \\
\hline & $290-300$ & 47.9 & 16.5 & 4.1 & 30.1 & 1.7 & 100.3 \\
\hline & $300-310$ & 34.1 & 13.0 & 3.4 & 44.9 & 5.6 & 101.0 \\
\hline & $340-350$ & 7.1 & 11.1 & 2.3 & 57.1 & 23.4 & 101.0 \\
\hline & $350-360$ & 7.7 & 10.4 & 2.0 & 62.1 & 18.4 & 100.6 \\
\hline & $390-400$ & 9.3 & 6.3 & 1.5 & 59.2 & 24.1 & 100.4 \\
\hline & $400-410$ & 8.9 & 7.6 & 1.5 & 49.9 & 33.0 & 100.9 \\
\hline TRAD. V-3b & $0-10$ & 6.2 & 0.0 & 1.6 & 75.2 & 15.9 & 98.9 \\
\hline & $20-30$ & 7.5 & 0.3 & 2.2 & 75.4 & 13.9 & 99.3 \\
\hline & $40-50$ & 13.7 & 0.7 & 2.3 & 69.0 & 14.4 & 100.1 \\
\hline & $90-100$ & 22.4 & 0.0 & 2.6 & 62.3 & 12.7 & 100.0 \\
\hline & $140-150$ & 19.8 & 1.0 & 2.5 & 64.9 & 12.6 & 100.8 \\
\hline & $190-200$ & 18.1 & 2.0 & 2.6 & 65.9 & 12.4 & 101.0 \\
\hline & $240-250$ & 16.5 & 4.5 & 2.8 & 65.7 & 10.7 & 100.2 \\
\hline & $290-300$ & 21.6 & 14.8 & 7.3 & 49.2 & 8.3 & 101.2 \\
\hline & 320 & 13.2 & 6.6 & 2.4 & 42.5 & 36.1 & 100.8 \\
\hline & 350 & 10.8 & 6.1 & 1.8 & 43.7 & 38.2 & 100.6 \\
\hline TRAD. V-2 & $0-10$ & 8.0 & 1.3 & 2.0 & 71.9 & 15.6 & 98.8 \\
\hline & $20-30$ & 8.9 & 0.8 & 2.3 & 73.0 & 14.6 & 99.6 \\
\hline & $40-50$ & 9.3 & 0.7 & 3.2 & 75.5 & 11.5 & 100.2 \\
\hline & 70 & 20.6 & 0.4 & 2.3 & 63.9 & 13.2 & 100.4 \\
\hline & $90-100$ & 22.2 & 0.9 & 2.4 & 62.3 & 12.4 & 100.2 \\
\hline & $140-150$ & 20.1 & 0.5 & 2.4 & 65.7 & 11.2 & 99.9 \\
\hline
\end{tabular}




\begin{tabular}{|c|c|c|c|c|c|c|c|}
\hline & $190-200$ & 18.8 & 2.5 & 2.6 & 62.9 & 13.2 & 100.0 \\
\hline & $240-250$ & 15.6 & 6.8 & 3.1 & 66.0 & 8.6 & 100.1 \\
\hline & $290-300$ & 22.3 & 9.4 & 3.0 & 61.0 & 5.3 & 101.0 \\
\hline \multirow[t]{8}{*}{ TRAD. VI-6 } & $0-10$ & 5.0 & 0.8 & 2.4 & 77.8 & 12.6 & 99.1 \\
\hline & $20-30$ & 6.1 & 1.7 & 2.2 & 77.5 & 12.6 & 100.1 \\
\hline & $40-50$ & 9.7 & 0.7 & 2.0 & 72.8 & 14.0 & 99.2 \\
\hline & $90-100$ & 23.2 & 1.0 & 2.3 & 60.9 & 13.0 & 100.4 \\
\hline & $140-150$ & 18.6 & 0.7 & 1.9 & 65.5 & 13.3 & 100.0 \\
\hline & $190-200$ & 18.2 & 1.4 & 2.2 & 65.3 & 12.7 & 99.8 \\
\hline & $240-250$ & 15.7 & 2.8 & 1.6 & 62.2 & 17.7 & 100.0 \\
\hline & $290-300$ & 13.1 & 4.5 & 1.4 & 64.5 & 16.9 & 100.4 \\
\hline \multirow[t]{8}{*}{ TRAD. VI-5 } & $0-10$ & 6.0 & 0.3 & 1.7 & 75.4 & 14.3 & 97.7 \\
\hline & $20-30$ & 4.9 & 1.0 & 2.0 & 76.4 & 14.6 & 98.9 \\
\hline & $40-50$ & 7.6 & 0.5 & 2.1 & 75.3 & 13.8 & 99.3 \\
\hline & $90-100$ & 24.2 & 0.4 & 2.5 & 61.1 & 11.5 & 99.7 \\
\hline & $140-150$ & 19.5 & 1.8 & 2.0 & 64.5 & 12.0 & 99.8 \\
\hline & $190-200$ & 18.2 & 1.8 & 2.0 & 64.5 & 12.0 & 99.5 \\
\hline & $240-250$ & 15.8 & 3.9 & 1.7 & 64.9 & 13.5 & 99.8 \\
\hline & $290-300$ & 10.4 & 8.6 & 1.9 & 57.2 & 22.5 & 100.6 \\
\hline \multirow[t]{11}{*}{ TRAD. VI-7 } & $0-10$ & 11.4 & 7.8 & 1.5 & 61.6 & 18.8 & 101.1 \\
\hline & $20-30$ & 5.3 & 0.7 & 2.1 & 78.2 & 12.2 & 99.5 \\
\hline & $40-50$ & 4.3 & 2.9 & 2.1 & 76.4 & 13.9 & 99.6 \\
\hline & $70-80$ & 8.2 & 1.5 & 2.5 & 74.2 & 13.3 & 99.7 \\
\hline & $90-100$ & 24.7 & 1.8 & 2.3 & 59.0 & 12.4 & 99.9 \\
\hline & $140-150$ & 23.4 & 1.8 & 2.3 & 60.2 & 12.2 & 99.3 \\
\hline & 180 & 17.5 & 1.9 & 1.8 & 64.5 & 13.6 & 100.3 \\
\hline & $190-200$ & 15.5 & 4.2 & 1.9 & 66.5 & 12.2 & 100.2 \\
\hline & $240-250$ & 13.8 & 4.3 & 1.7 & 66.8 & 13.5 & 101.1 \\
\hline & 260 & 12.4 & 5.6 & 1.3 & 63.4 & 18.3 & 100.0 \\
\hline & $290-300$ & 11.3 & 8.3 & 1.5 & 61.7 & 17.1 & 100.3 \\
\hline \multirow{8}{*}{ TRAD. VI-8 } & $0-10$ & 11.1 & 6.4 & 1.1 & 63.0 & 18.6 & 98.4 \\
\hline & $20-30$ & 4.4 & 1.3 & 1.5 & 76.7 & 14.4 & 100.1 \\
\hline & $40-50$ & 5.5 & 2.6 & 2.4 & 74.8 & 14.7 & 99.7 \\
\hline & $70-80$ & 14.8 & 1.6 & 2.4 & 67.1 & 13.7 & 100.3 \\
\hline & $90-100$ & 20.6 & 2.7 & 2.3 & 62.9 & 12.2 & 100.7 \\
\hline & $140-150$ & 15.3 & 4.2 & 1.8 & 67.2 & 12.2 & 100.8 \\
\hline & $190-200$ & 12.4 & 8.8 & 1.7 & 72.2 & 5.8 & 101.0 \\
\hline & $240-250$ & 12.2 & 11.4 & 1.7 & 73.0 & 2.6 & 101.0 \\
\hline \multirow{8}{*}{ TRAD. VI-4 } & $0-10$ & 4.5 & 1.6 & 2.1 & 76.7 & 14.2 & 99.1 \\
\hline & $20-30$ & 5.4 & 1.9 & 2.3 & 75.6 & 14.5 & 99.7 \\
\hline & $40-50$ & 8.6 & 1.7 & 2.3 & 73.1 & 14.3 & 100.0 \\
\hline & 70 & 21.0 & 2.0 & 2.2 & 62.4 & 12.4 & 100.1 \\
\hline & $90-100$ & 23.0 & 7.0 & 2.0 & 59.5 & 14.1 & 105.7 \\
\hline & 110 & 17.2 & 5.2 & 2.1 & 61.3 & 15.3 & 101.0 \\
\hline & $140-150$ & 13.3 & 6.6 & 1.7 & 54.4 & 24.4 & 100.5 \\
\hline & 200 & 10.9 & 4.9 & 1.5 & 52.1 & 30.9 & 100.3 \\
\hline
\end{tabular}




\begin{tabular}{|cccccccc|} 
& 250 & 11.6 & 3.0 & 1.2 & 49.6 & 35.3 & 100.8 \\
& 300 & 7.8 & 1.0 & 1.1 & 36.0 & 54.1 & 100.1 \\
& 350 & 9.8 & 3.7 & 1.5 & 44.0 & 41.5 & 100.5 \\
& 360 & 9.8 & 4.6 & 1.3 & 41.7 & 43.5 & 101.0 \\
TRAD. VI-12 & $0-10$ & 3.8 & 1.1 & 1.5 & 75.7 & 16.6 & 98.8 \\
& $20-30$ & 5.0 & 1.1 & 1.6 & 70.5 & 20.9 & 99.1 \\
& 50 & 6.9 & 1.3 & 1.8 & 67.3 & 22.7 & 100.0 \\
& 70 & 12.6 & 0.5 & 2.1 & 65.1 & 19.5 & 99.9 \\
& 80 & 17.5 & 0.7 & 2.0 & 63.1 & 16.8 & 100.2 \\
& 100 & 17.5 & 1.4 & 2.1 & 57.5 & 21.3 & 99.9 \\
& 150 & 11.8 & 2.8 & 1.8 & 36.2 & 47.6 & 100.2 \\
TRAD. VI-11 & $0-10$ & 4.8 & 0.6 & 1.7 & 75.4 & 16.1 & 98.7 \\
& $20-30$ & 8.6 & 0.9 & 1.8 & 70.9 & 17.1 & 99.5 \\
& $40-50$ & 13.9 & 1.6 & 2.0 & 69.1 & 13.5 & 100.2 \\
& 70 & 17.9 & 1.6 & 2.1 & 66.5 & 12.0 & 100.1 \\
& 100 & 17.7 & 3.3 & 2.4 & 66.3 & 10.3 & 100.1 \\
& 150 & 12.7 & 1.6 & 1.2 & 53.4 & 31.4 & 100.3 \\
& 200 & 18.2 & 11.1 & 2.1 & 64.8 & 4.5 & 100.7 \\
& & & & & & & \\
TRAD. I-3 & $0-10$ & 10.3 & 2.4 & 2.4 & 69.9 & 12.4 & 97.5 \\
& $20-30$ & 15.3 & 3.4 & 2.8 & 70.4 & 6.7 & 98.6 \\
& $40-50$ & 17.1 & 4.3 & 1.9 & 70.7 & 5.5 & 99.5 \\
& $90-100$ & 15.8 & 3.3 & 1.5 & 76.1 & 3.4 & 100.1 \\
& $140-150$ & 15.0 & 4.8 & 2.8 & 67.1 & 10.7 & 100.4 \\
& $190-200$ & 14.6 & 2.7 & 1.1 & 74.3 & 7.4 & 100.2 \\
\hline
\end{tabular}


QUADRO 5 - Resultados das análises químicas ${ }^{1}$

\begin{tabular}{|c|c|c|c|c|c|c|c|c|c|c|c|c|c|}
\hline $\begin{array}{l}\text { amostra } \\
\mathrm{cm}\end{array}$ & $\begin{array}{l}\mathbf{p H} \\
\mathrm{CaCl}_{2}\end{array}$ & $\begin{array}{l}\text { M.O. } \\
\%\end{array}$ & $\begin{array}{l}\mathbf{P} \\
\left(\mathrm{ug} / \mathrm{cm}^{3}\right)\end{array}$ & $k^{+}$ & $\mathrm{Ca}^{2^{+}}$ & $\begin{array}{l}\mathbf{M g}^{2^{+}} \\
\mathrm{meq} / 100\end{array}$ & $\begin{array}{c}\mathrm{Al}^{3^{+}} \\
\mathrm{cm} 3\end{array}$ & $\mathrm{H}^{+}+\mathrm{Al}^{3+}$ & $\mathbf{s}$ & $\mathbf{T}$ & $\mathbf{v}$ & $\begin{array}{l}\mathbf{m} \\
\%\end{array}$ & $\%$ \\
\hline V1 0-10 & 5.2 & 1.5 & 7 & 0.30 & 0.8 & 0.6 & 0.0 & 1.8 & 1.7 & 3.5 & 49 & 0 & \\
\hline V1 $20-30$ & 4.3 & 1.4 & 3 & 0.21 & 0.8 & 0.2 & & 2.5 & 1.2 & 3.7 & 32 & 0 & \\
\hline V1 40-50 & 4.2 & 1.3 & 2 & 0.07 & 0.1 & 0.2 & 0.7 & 2.8 & 0.4 & 3.2 & 13 & 64 & \\
\hline V1 90-100 & 4.0 & 0.9 & 2 & 0.04 & 0.2 & 0.1 & & 2.5 & 0.3 & 2.8 & 11 & & \\
\hline V1 140-150 & 4.1 & 0.8 & 1 & 0.03 & 0.4 & 0.1 & & 2.0 & 0.5 & 2.5 & 20 & & \\
\hline V1 190-200 & 4.2 & 0.7 & 1 & 0.05 & 0.1 & 0.1 & 0.7 & 2.0 & 0.3 & 2.3 & 13 & 70 & \\
\hline V1 240-250 & 4.0 & 0.7 & 1 & 0.03 & 0.1 & 0.1 & 0.6 & 1.6 & 0.2 & 1.8 & 11 & 75 & \\
\hline V1 390-400 & 4.2 & 0.7 & 3 & 0.04 & 0.2 & 0.1 & 0.4 & 1.1 & 0.3 & 1.4 & 21 & 57 & \\
\hline V1 540-550 & 4.0 & 0.7 & 1 & 0.08 & 0.1 & 0.1 & 0.4 & 1.5 & 0.3 & 1.8 & 17 & 57 & \\
\hline V1 690-700 & 4.3 & 0.7 & 1 & 0.05 & 0.1 & 0.1 & 0.4 & 1.3 & 0.3 & 1.6 & 19 & 57 & \\
\hline V4 $0-10$ & 4.9 & 2.6 & 17 & 0.39 & 1.4 & 0.7 & 0.0 & 1.8 & 2.5 & 4.3 & 58 & 0 & \\
\hline V4 20-30 & 4.3 & 1.2 & 3 & 0.17 & 0.3 & 0.1 & 1.1 & 3.8 & 0.6 & 4.4 & 14 & 65 & \\
\hline V4 $30-40$ & 4.0 & 1.3 & 2 & 0.08 & 0.2 & 0.1 & & 3.4 & 0.4 & 3.8 & 11 & & \\
\hline V4 40-50 & 4.2 & 1.2 & 2 & 0.07 & 0.2 & 0.1 & & 3.4 & 0.4 & 3.8 & 11 & & \\
\hline V4 90-100 & 3.8 & 0.9 & 1 & 0.05 & 0.1 & 0.1 & & 2.5 & 0.3 & 2.8 & 11 & & \\
\hline V4 140-150 & 3.9 & 0.8 & 1 & 0.05 & 0.1 & 0.1 & 1.0 & 2.2 & 0.3 & 2.5 & 12 & 77 & \\
\hline V4 290-300 & 4.1 & 0.7 & 5 & 0.06 & 0.1 & 0.1 & & 1.6 & 0.3 & 1.9 & 16 & & \\
\hline V4 390-400 & 4.0 & 0.7 & 3 & 0.06 & 0.1 & 0.1 & & 1.5 & 0.3 & 1.8 & 17 & & \\
\hline V5a 0-10 & 4.7 & 2.0 & 25 & 0.36 & 1.0 & 0.5 & 0.2 & 2.0 & 1.9 & 3.9 & 49 & 10 & \\
\hline V5a 20-30 & 4.3 & 1.1 & 3 & 0.08 & 0.6 & 0.1 & 0.7 & 2.8 & 0.8 & 3.6 & 22 & 47 & \\
\hline V5a $40-50$ & 4.1 & 1.3 & 3 & 0.06 & 0.4 & 0.1 & & 3.1 & 0.6 & 3.7 & 16 & & \\
\hline V5a 90-100 & 3.9 & 0.8 & 1 & 0.05 & 0.4 & 0.1 & & 2.5 & 0.6 & 3.1 & 19 & & \\
\hline V5a290-300 & 4.0 & 0.7 & 2 & 0.08 & 0.4 & 0.1 & 0.6 & 1.5 & 0.6 & 2.1 & 29 & 50 & \\
\hline V5a390-400 & 4.3 & 0.7 & 2 & 0.17 & 0.2 & 0.1 & 0.6 & 1.6 & 0.5 & 2.1 & 24 & 55 & \\
\hline V3b 0-10 & 4.7 & 2.1 & 18 & 0.84 & 1.0 & 0.6 & 0.0 & 2.0 & 2.4 & 4.4 & 55 & 0 & \\
\hline V3b 20-30 & 4.6 & 1.2 & 4 & 0.72 & 0.5 & 0.2 & 0.5 & 2.5 & 1.4 & 3.9 & 36 & 26 & \\
\hline V3b 40-50 & 3.9 & 1.1 & 2 & 0.23 & 0.6 & 0.1 & 1.8 & 4.7 & 0.9 & 5.6 & 16 & 67 & \\
\hline V3b 90-100 & 4.0 & 0.9 & 1 & 0.13 & 0.5 & 0.1 & 3.4 & 6.4 & 0.7 & 7.1 & 10 & 83 & \\
\hline V3b140-150 & 3.7 & 0.7 & 3 & 0.16 & 0.4 & 0.2 & 2.8 & 4.7 & 0.8 & 5.5 & 15 & 78 & \\
\hline VI6 0-10 & 4.8 & 2.1 & 10 & 0.24 & 1.3 & 0.7 & & 2.0 & 2.2 & 4.2 & 52 & & \\
\hline VI6 20-30 & 4.0 & 1.0 & 3 & 0.28 & 0.6 & 0.2 & & 2.0 & 1.1 & 3.1 & 35 & & \\
\hline VI6 40-50 & 4.1 & 0.9 & 1 & 0.24 & 0.7 & 0.2 & & 3.1 & 1.1 & 4.2 & 26 & & \\
\hline VI6 90-100 & 4.0 & 0.9 & 1 & 0.08 & 0.8 & 0.1 & 3.4 & 6.4 & 1.0 & 7.4 & 14 & 77 & \\
\hline
\end{tabular}

${ }^{1}$ Análises realizadas no Depto. de Ciência do Solo / ESALQ-USP. 


\begin{tabular}{|c|c|c|c|c|c|c|c|c|c|c|c|c|}
\hline $\begin{array}{l}\text { VI6140-150 } \\
\text { VI6290-300 }\end{array}$ & $\begin{array}{l}3.8 \\
4.0\end{array}$ & $\begin{array}{l}0.7 \\
0.6\end{array}$ & $\begin{array}{l}1 \\
1\end{array}$ & $\begin{array}{l}0.07 \\
0.07\end{array}$ & $\begin{array}{l}0.4 \\
0.4\end{array}$ & $\begin{array}{l}0.1 \\
0.1\end{array}$ & $\begin{array}{l}2.8 \\
2.8\end{array}$ & $\begin{array}{l}4.2 \\
4.2\end{array}$ & $\begin{array}{l}0.6 \\
0.6\end{array}$ & $\begin{array}{l}4.8 \\
4.8\end{array}$ & $\begin{array}{l}13 \\
13\end{array}$ & $\begin{array}{l}82 \\
83\end{array}$ \\
\hline VI7 0-10 & 4.5 & 2.1 & 21 & 0.31 & 1.2 & 0.6 & 0.0 & 2.2 & 2.1 & 4.3 & 49 & 0 \\
\hline VI7 20-30 & 4.0 & 1.3 & 4 & 0.11 & 0.7 & 0.2 & & 2.5 & 1.0 & 3.5 & 29 & \\
\hline VI7 40-50 & 4.1 & 0.8 & 1 & 0.06 & 0.5 & 0.1 & & 3.1 & 0.7 & 3.8 & 18 & \\
\hline VI7 70-80 & 4.0 & 1.1 & 2 & 0.08 & 1.2 & 0.2 & 3.2 & 7.2 & 1.5 & 8.7 & 17 & 60 \\
\hline VI7 90-100 & 3.8 & 0.8 & 1 & 0.07 & 0.7 & 0.1 & 3.6 & 8.0 & 0.9 & 8.9 & 10 & 80 \\
\hline VI7 180 & 3.6 & 0.7 & 2 & 0.08 & 0.5 & 0.2 & 4.9 & 8.8 & 0.8 & 9.6 & 8 & 86 \\
\hline VI4 0-10 & 4.9 & 2.6 & 21 & 0.43 & 1.4 & 0.8 & 0.0 & 2.2 & 2.6 & 4.8 & 54 & 0 \\
\hline VI4 20-30 & 3.9 & 1.0 & 3 & 0.11 & 0.4 & 0.1 & 1.1 & 2.8 & 0.6 & 3.4 & 18 & 65 \\
\hline VI4 40-50 & 4.2 & 0.9 & 2 & 0.08 & 0.6 & 0.1 & 1.7 & 3.1 & 0.8 & 3.9 & 21 & 68 \\
\hline VI4 70 & 3.9 & 1.1 & 1 & 0.08 & 1.4 & 0.2 & 2.6 & 6.4 & 1.7 & 8.1 & 21 & 60 \\
\hline VI4 90-100 & 4.0 & 0.9 & 2 & 0.08 & 1.0 & 0.1 & 3.6 & 6.4 & 1.2 & 7.6 & 16 & 75 \\
\hline VI11 0-10 & 4.3 & 2.1 & 11 & 0.27 & 1.1 & 0.5 & 0.4 & 2.8 & 1.9 & 4.7 & 40 & 17 \\
\hline VI11 20-30 & 4.1 & 1.2 & 2 & 0.09 & 0.6 & 0.2 & 2.0 & 4.2 & 0.9 & 5.1 & 18 & 69 \\
\hline VI11 40-50 & 3.9 & 0.9 & 2 & 0.08 & 0.5 & 0.3 & 2.7 & 4.7 & 0.9 & 5.6 & 16 & 75 \\
\hline VI11 70 & 4.0 & 0.9 & 1 & 0.07 & 0.4 & 0.4 & 4.4 & 7.2 & 0.9 & 8.1 & 11 & 83 \\
\hline $\begin{array}{l}\text { amostra } \\
\mathrm{cm}\end{array}$ & $\begin{array}{l}\mathrm{SiO}_{2} \\
\%\end{array}$ & $\begin{array}{l}\mathrm{Al}_{2} \mathrm{O}_{3} \\
\%\end{array}$ & & $\begin{array}{l}\mathrm{Fe}_{2} \mathrm{O}_{3} \\
\%\end{array}$ & & $\begin{array}{l}\mathrm{TiO}_{2} \\
\%\end{array}$ & & $\begin{array}{l}\text { MnO } \\
\%\end{array}$ & $\mathbf{K i}$ & & $\mathrm{Kr}$ & \\
\hline V1 20-30 & 3.50 & 1.27 & & 0.44 & & 0.10 & & 0.01 & 4.69 & & 3.83 & \\
\hline V1 90-100 & 5.70 & 3.11 & & 1.03 & & 0.13 & & 0.01 & 3.12 & & 2.57 & \\
\hline V1 140-150 & 5.20 & 3.37 & & 0.89 & & 0.18 & & 0.01 & 2.62 & & 2.24 & \\
\hline V1 290-300 & 4.90 & 4.13 & & 0.97 & & 0.15 & & 0.01 & 2.02 & & 1.75 & \\
\hline V1 590-600 & 6.00 & 4.90 & & 1.13 & & 0.20 & & 0.01 & 2.08 & & 1.81 & \\
\hline V4 0-10 & 2.90 & 2.60 & & 0.55 & & 0.08 & & 0.01 & 1.90 & & 1.67 & \\
\hline V4 30-40 & 9.40 & 3.54 & & 0.69 & & 0.12 & & 0.01 & 4.51 & & 4.01 & \\
\hline V4 40-50 & 5.00 & 2.35 & & 0.66 & & 0.13 & & 0.01 & 3.62 & & 3.07 & \\
\hline V4 90-100 & 6.00 & 3.62 & & 0.95 & & 0.21 & & 0.01 & 2.82 & & 2.41 & \\
\hline V4 290-300 & 4.50 & 3.37 & & 0.87 & & 0.15 & & 0.01 & 2.27 & & 1.95 & \\
\hline V4 390-400 & 5.30 & 3.88 & & 1.03 & & 0.18 & & 0.01 & 2.32 & & 1.98 & \\
\hline V5a 0-10 & 2.80 & 2.09 & & 0.36 & & 0.06 & & 0.01 & 2.28 & & 2.05 & \\
\hline V5a 40-50 & 5.10 & 2.86 & & 0.60 & & 0.15 & & 0.01 & 3.03 & & 2.67 & \\
\hline V5a 90-100 & 4.80 & 3.37 & & 0.86 & & 0.19 & & 0.01 & 2.42 & & 2.08 & \\
\hline V5a140-150 & 5.90 & 3.88 & & 0.02 & & 0.21 & & 0.01 & 2.59 & & 2.24 & \\
\hline VI6 0-10 & 2.80 & 1.78 & & 0.17 & & 0.13 & & 0.01 & 2.67 & & 2.52 & \\
\hline VI6 20-30 & 3.20 & 2.28 & & 0.19 & & 0.10 & & 0.01 & 2.38 & & 2.26 & \\
\hline VI6 40-50 & 1.60 & 1.84 & & 0.43 & & 0.18 & & 0.01 & 1.48 & & 1.29 & \\
\hline VI6 90-100 & 9.29 & 7.58 & & 1.69 & & 0.26 & & 0.01 & 2.08 & & 1.82 & \\
\hline VI6190-200 & 7.37 & 5.25 & & 1.32 & & 0.13 & & 0.04 & 2.39 & & 2.06 & \\
\hline
\end{tabular}




\begin{tabular}{|c|c|c|c|c|c|c|c|}
\hline VI6290-300 & 5.76 & 3.92 & 0.52 & 0.04 & 0.01 & 2.50 & 2.30 \\
\hline VI7 0-10 & 2.80 & 1.84 & 0.21 & 0.09 & 0.01 & 2.59 & 2.41 \\
\hline VI7 20-30 & 3.90 & 2.29 & 0.22 & 0.18 & 0.01 & 2.90 & 2.73 \\
\hline VI7 40-50 & 3.70 & 1.53 & 0.26 & 0.15 & 0.01 & 4.11 & 3.71 \\
\hline VI7140-150 & 8.28 & 5.25 & 0.76 & 0.16 & 0.01 & 2.68 & 2.45 \\
\hline VI7190-200 & 7.37 & 4.17 & 0.71 & 0.06 & 0.01 & 3.00 & 2.71 \\
\hline VI12 0-10 & 2.50 & 1.53 & 0.05 & 0.06 & 0.01 & 2.78 & 2.72 \\
\hline VI12 50 & 4.10 & 2.86 & 0.19 & 0.10 & 0.01 & 2.44 & 2.34 \\
\hline VI12 80 & 8.69 & 5.25 & 0.22 & 0.16 & 0.01 & 2.81 & 2.74 \\
\hline
\end{tabular}




\begin{abstract}
ANEXO II
Descrição morfológica das trincheiras da Topossequência Retiro I

A apresentação da descrição das trincheiras foi feita com o intuito de correlacionar a descrição de seus horizontes à descrição da Topossequência Retiro I como um todo. Foi tomado o cuidado de não se perder o detalhamento da descrição de cada horizonte e subhorizontes das trincheiras e ao mesmo tempo enquadrá-los à generalização dos horizontes na escala de representação da topossequência. Os números dos volumes estão relacionados aos números indicados nos desenhos das trincheiras (rever FIGURAS 8 a 11), como a seguir:
\end{abstract}

\title{
TRINCHEIRA SPFR 14:
}

\section{HORIZONTE A:}

volume $1-0-30 \mathrm{~cm}$ : bruno-avermelhado (5YR 4/4), úmido. Numerosos volumes de areia lavada e grãos isolados bruno-amarelado-claros (5YR 6/4) centimétricos, alongados. Observando-se com a lupa nota-se que a cor do esqueleto vai de incolor a vermelho-claro. A maioria dos grãos é bem arredondada. Textura muito arenosa; estrutura fraca média poliédrica; porosidade intergranular forte, com alojamentos de raízes tubulares; transição clara e irregular.

\section{HORIZONTE DE TRANSIÇÃO E/ E COM BANDAS (Eb):}

volume 2 - 30-90cm: cor um pouco mais vermelha e mais escura que o anterior. Ligeira heterogeneidade: manchas formando rede fina bruno-avermelhado-escura (2,5YR 3/3,5), fundo mais vivo vermelho-amarelado (5YR 4/6); úmido; textura muito arenosa; com a lupa se observa os grãos de quartzo incolores muito menos abundantes dominando os grãos de cor bruno-avermelhada; estrutura fraca média poliédrica, porosidade idêntica ao anterior; coesão muito fraca. 
As primeiras bandas onduladas aparecem no meio deste horizonte. A primeira é descontínua, a segunda bifurcada (espessura $1 \mathrm{~cm}$ ); cor das bandas é vermelhoescuro-acinzentado (2,5YR 3/3,5), cor da matriz é bruno-avermelhada (5YR 4/4). As bandas são um pouco mais resistentes à faca; a porosidade intergranular é menos desenvolvida do que na matriz e os poros tubulares mais abundantes; a textura é um pouco mais argilosa, permanecendo arenosa; transição clara e plana.

\section{HORIZONTE E COM BANDAS ONDULADAS (Eb):}

volume 3 - 90-125cm: bruno-avermelhado (2,5YR 3,5/6 um pouco menos vermelho e homogêneo); úmido; textura um pouco mais argilosa do que o $E$, mas ainda arenosa. Os grãos incolores são ainda menos abundantes. A cor dominante da película dos grãos de quartzo é bruno-avermelhada mais viva do que a cor geral e não se vê o plasma com a lupa. Porosidade tubular e intergranular forte. Bandas idênticas ao anterior; transição clara e plana.

volume 4 - 125-160cm: um pouco mais vermelho e mais claro (2,5YR 3,5/6); úmido; textura arenosa a areno-argilosa; diminuem os quartzos incolores; estrutura maciça com fratura irregular; porosidade intergranular e tubular bem desenvolvida; coesão muito fraca; bandas idênticas ao anterior; transição difusa e plana.

volume 5 - 160-210cm+: cor um pouco mais viva (vermelho-escuro, 2,5YR 4/6); mesma textura. Os grãos incolores são ainda menos abundantes, mas presentes. Os grãos são vermelhos por películas de plasma. Estrutura maciça com fratura ligeiramente conchoidal, localmente com tendência poliédrica. Pontualmente existem volumes centimétricos de areia lavada branca associados aos poros tubulares; porosidade intergranular forte com alguns poros tubulares; coesão muito fraca.

As bandas são um pouco mais escuras em relação ao fundo, são vermelho-escuroacinzentadas (2,5YR 3/4), elas são menos porosas, contém mais plasma (tendência porfirosquélica), apresentam uma porosidade principalmente tubular e uma textura nitidamente areno-argilosa. 


\section{TRINCHEIRA SPFR 8:}

\section{HORIZONTE E:}

volume 1 - 0-45cm: bruno-avermelhado (5YR 4/4), não possuindo volumes esbranquiçados de areia lavada (grãos incolores pouco abundantes); estrutura fraca média poliédrica; porosidade tubular e intergranular forte; coesão muito fraca; transição clara e plana.

\section{HORIZONTE E COM BANDAS ONDULADAS (Eb):}

volume 2 - 45-70cm: um pouco mais vermelho e mais claro (entre bruno-avermelhado, 5YR 4/4 e vermelho-escuro-acinzentado, 2,5YR 3,5/4); textura arenosa a arenoargilosa; estrutura fraca média poliédrica; porosidade intergranular e tubular, esta última sendo mais desenvolvida do que acima; coesão muito fraca. As bandas onduladas são ligeiramente heterogêneas com manchas (rede) bruno-avermelhadas isolando pequenos domínios mais vermelhos. Estas bandas são um pouco mais resistentes à faca e mais argilosas que as anteriores. Transição gradual e plana.

volume 3 - 70-97cm: mais vermelho que o anterior $(2,5 \mathrm{YR} 4 / 6$ um pouco menos vermelho); areno-argiloso e com a lupa o plasma é mais visível, sendo que os grãos incolores parecem mais abundantes; estrutura fraca média poliédrica; porosidade intergranular e tubular forte (a porosidade tubular é mais desenvolvida); coesão muito fraca. As bandas onduladas têm cor ligeiramente mais vermelha, apresentam um plasma mais abundante, com tendência porfirosquélica e são constituídas por volumes anastomosados, mais vermelhos e mais compactos (elas não são contínuas); transição gradual e plana.

volume 4 - 97-153cm: ligeiramente mais vermelho e mais vivo (vermelho-escuro, 2,5YR 4/6); textura areno-argilosa a argilo-arenosa; raros quartzos incolores; estrutura fraca média poliédrica; mesma porosidade que o anterior; coesão muito fraca; transição gradual e plana.

As bandas onduladas são mais espessas, frequentemente anastomosadas. Elas são também constituídas por volumes centimétricos de material mais vermelho e mais argiloso que localmente invadem toda a banda. Ela apresenta uma estrutura maciça com fratura plana; transição progressiva. 
volume 5 - 153-220cm+: um pouco mais vivo (2,5YR 4/8); textura um pouco mais argilosa com poucos quartzos sem cores; estrutura maciça com fratura finamente conchoidal ou plana; porosidade intergranular e tubular; coesão muito fraca.

\section{TRINCHEIRA 10:}

\section{HORIZONTE A:}

volume 1 - 0-10 cm: bruno-avermelhado (5YR 5/4); muito arenoso com presença de areia lavada; estrutura fraca pequena poliédrica; porosidade intergranular forte, raízes abundantes, que diminuem a partir de $15 \mathrm{~cm}$, permanecem abundantes até $100 \mathrm{~cm}$, mas estão presentes até a base; coesão muito fraca; transição gradual plana.

\section{HORIZONTE E:}

volume $2-10-40 \mathrm{~cm}$ : um pouco mais claro (5YR 5/4); arenoso com areia lavada ou limpa associada a certos poros; estrutura maciça; porosidade tubular e sobretudo intergranular forte; coesão média (seco); transição clara e plana.

\section{HORIZONTE DE TRANSIÇÃO E/Bt:}

volume 3 - 40-70cm: vermelho-amarelado (5YR 4/6), arenoso com um pouco de argila, presença de numerosos volumes milimétricos mais claros que correspondem às areias limpas, sendo praticamente tubulares na base. Presença de uma banda ondulada de $1 \mathrm{~cm}$ bruno-avermelhada (5YR 4/6) mais vermelha. Esta banda é mais rica em plasma e praticamente não contém areia limpa e é menos porosa; a estrutura é maciça com fratura conchoidal; a porosidade é tubular bastante grosseira de 1 a $2 \mathrm{~mm}$ e intergranular bem desenvolvida; transição abrupta e plana.

\section{HORIZONTE Bt:}

volume 4 - 70-100 cm: nitidamente mais vermelho $(2,5 \mathrm{YR}$ 4/6 um pouco menos vermelho), presença de volumes mais claros milimétricos associados aos poros e constituídos por areia lavada. Este horizonte é mais duro à faca que o precedente; estrutura maciça com fratura conchoidal; coesão média. Presença de bandas 
onduladas muito pouco visíveis com espessura de 1 a $2 \mathrm{~cm}$, ligeiramente mais escuras, contendo um pouco mais de plasma do que a interbanda. A cor das bandas é vermelhoescura (2,5YR 3/6); textura arenosa a areno-argilosa; coesão forte; transição gradual e plana.

volume 5 - 100-135cm: vermelho mais vivo (2,5YR 4/6); areno-argiloso; presença de alguns volumes milimétricos de areia limpa, menos abundantes do que acima e associados aos poros; estrutura maciça a poliédrica pouco nítida; porosidade tubular e intergranular medianamente desenvolvida; coesão média a forte. Este horizonte é mais duro (com a faca e com a picareta). Presença de bandas onduladas mais escuras e menos porosas; transição gradual e plana.

\section{HORIZONTE C1b:}

volume 6 - 135-155cm+: vermelho mais claro (2,5YR 4,5/7); textura arenosa com um pouco de argila; estrutura maciça com fratura conchoidal, horizonte pouco duro à faca; a porosidade é principalmente intergranular forte com alguns poros tubulares; coesão fraca. Presença de bandas onduladas muito pouco contrastadas, parecendo descontínuas, com espessura de 1 a $2 \mathrm{~cm}$, ligeiramente mais compactas, mais coerentes e com mais plasma.

\section{TRINCHEIRA 11:}

\section{FACE MONTANTE:}

\section{HORIZONTE A:}

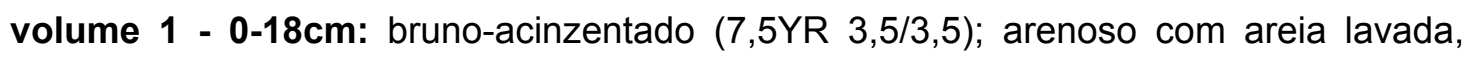
formando pequenos volumes (milimétricos) ao redor dos poros; estrutura muito fraca média poliédrica; porosidade tubular e intergranular forte; coesão quase nula (úmido); transição gradual e plana. 


\section{HORIZONTE E:}

volume 2 - 18-38cm: bruno-avermelhado (5YR 4/4); arenoso; estrutura muito fraca média poliédrica; porosidade tubular e intregranular forte; coesão quase nula; transição gradual e plana.

\section{HORIZONTE DE TRANSIC̣ÃO E/Bt:}

volume 3 - 38-55cm: vermelho-amarelado (5YR 4/5); arenoso; estrutura maciça com tendência a poliédrica; porosidade tubular e intergranular forte; coesão quase nula. Com a lupa observa-se a presença de um retículo fino mais vermelho englobando domínios mais brunos; transição clara e ondulada.

\section{HORIZONTE Bt:}

volume 4 - 55-80cm: um pouco mais resistente à faca e um pouco mais escuro, brunoavermelhado (5YR 3,5/4), o retículo vermelho é mais nítido; areno-argiloso; estrutura maciça com fratura conchoidal; porosidade tubular mais grosseira que o anterior e intergranular bem desenvolvida; coesão quase nula; transição clara e ondulada.

Apresenta banda ondulada um pouco mais escura que o Bt pouco desenvolvido (5YR $3,5 / 4)$; arenosa a areno-argilosa; nitidamente mais compacta, mas permanece com porosidade média; coesão um pouco mais fraca.

volume 5 - 80-105cm: mais vermelho e mais claro, vermelho-escuro (5YR/2,5YR 4/6); arenoso a areno-argiloso; estrutura muito fraca média poliédrica; porosidade intergranular bem desenvolvida e com alguns poros tubulares; coesão quase nula; transição clara e ondulada.

Apresenta uma banda ondulada de cor bruno-avermelhada (5YR 4/6) um pouco mais vermelha. A outra banda é um pouco mais escura que o material adjacente (5YR 4/6) um pouco mais vermelha, menos argilosa e menos compacta que a anterior, na base do Bt pouco desenvolvido.

volume 6 - 105-125cm: mais vermelho e mais claro, vermelho-escuro (2,5YR 4/6); arenoso a areno-argiloso; estrutura maciça com fratura conchoidal; porosidade intergranular bem desenvolvida com alguns poros tubulares; coesão quase nula; transição gradual e ondulada. 
Apresenta uma banda na base do perfil um pouco mais escura e mais larga que a descrita anteriormente e outra mais escura, mais coerente, mais compacta e com um pouco mais de argila que esta.

\section{HORIZONTE C1b:}

volume 7 - 125-175cm+: um pouco mais vermelho, vermelho-escuro $(2,5 \mathrm{YR} 4 / 6)$; arenoso; estrutura maciça com fratura quase plana; porosidade intergranular bastante desenvolvida com alguns poros tubulares; coesão muito fraca.

A passagem da face montante para a face jusante se dá pela coalescência das bandas onduladas dentro do horizonte Bt. Na face montante o Bt aparece pouco desenvolvido e as bandas onduladas são nítidas. Para jusante, as bandas se tornam cada vez menos visíveis até desaparecerem dentro do $\mathrm{Bt}$, que se torna mais nítido.

\section{FACE JUSANTE:}

\section{HORIZONTE A:}

volume 1 - 0-25cm: bruno dominante (7,5YR 4/4), úmido, com volumes de areia lavada milimétricos, com um retículo ligeiramente mais vermelho (inferior a $1 \mathrm{~mm}$ ) englobando domínios arenosos com areia mais ou menos lavada; muito arenoso; estrutura fraca média poliédrica; porosidade intergranular e tubular muito bem desenvolvida; coesão fraca; transição abrupta e ondulada sublinhada por uma banda ondulada mais vermelha de $0,5 \mathrm{~cm}$.

\section{HORIZONTE E:}

volume 2 - 25-80cm: bruno-avermelhado (5YR 3,5/4) um pouco menos vermelho; presença do retículo, mas menos nítido, porém mais vermelho e com domínios arenosos brunos; arenoso a areno-argiloso; estrutura fraca média poliédrica; porosidade idem ao anterior, mas menos desenvolvida, porém ainda forte; coesão muito fraca; transição abrupta e ondulada.

\section{HORIZONTE DE TRANSIÇÃO E/Bt:}

volume 3 - 80-110cm: ligeiramente mais escuro que $O$ anterior e ligeiramente homogêneo; fundo bruno-avermelhado-escuro (5YR3/4) e domínios mais claros bruno- 
avermelhados (5YR4/4); areno-argiloso; estrutura maciça com fratura regular plana um pouco conchoidal; porosidade tubular e intergranular nos domínios mais claros e menos desenvolvida que no horizonte acima; coesão fraca; transição gradual e ondulada.

Existem bandas pouco contrastadas e descontínuas, mas formadas de um retículo mais vermelho e compacto.

\section{HORIZONTE Bt:}

volume 4 - 110-140cm: vermelho-escuro (2,5YR 4/6); areno-argiloso; estrutura maciça com fratura ligeiramente conchoidal; porosidade intergranular e tubular mais fina que acima; coesão fraca. Apresenta bandas mais nítidas e pouco contrastadas; transição gradual e ondulada.

volume 5 - 140-170 cm+: vermelho (10YR 4/6), homogêneo fora das bandas; textura arenosa; presença de bandas mais contrastadas que acima, finas, um pouco mais escuras e mais compactas.

\section{TRINCHEIRA 3:}

\section{HORIZONTE A:}

volume 1 - 0-8cm: bruno (7,5YR 4/3) com manchas difusas e pequenas; arenoso com muita areia lavada; estrutura poliédrica grande e fraca com muitas raízes fasciculadas; transição clara e plana.

\section{HORIZONTE E:}

volume 2 - 8-27cm: três cores: bruno dominante (7,5YR 4/4) e volumes milimétricos de areia lavada bruno-clara (7,5YR 6/4) e bruno-avermelhada (5YR 4/3) em volumes um pouco maiores difusos milimétricos; arenoso com um pouquinho de argila; maciço; as raízes diminuem; transição difusa e plana.

\section{HORIZONTE DE TRANSIÇÃO E/Bt:}

volume 3 - 27-63/73cm: bruno-amarelado (5YR 4/6) com volume bruno-avermelhado (5YR 4/3) com areia lavada, mais contrastada, maior em tamanho (volumes 
centimétricos) e mais dispersa; presença de volumes mais vermelhos similares ou subjacente e uma bandinha vermelha; porosidade intergranular; no mais idem; transição difusa e ondulada.

\section{HORIZONTE Bt:}

volume 4 - 63/73-112cm: vermelho-escuro (2,5YR 4/6) homogêneo; areno-argiloso; estrutura muito fraca grande poliédrica; porosidade tubular; úmido com mais raízes; presença de três bandas pouco contrastadas, contínuas, paralelas na base; transição plana e difusa.

\section{HORIZONTE C1b:}

volume 5 - 112-120cm+: vermelho-escuro (2,5YR 4/8); areno-argiloso; estrutura maciça; sem bandas.

\section{TRINCHEIRA 5:}

\section{HORIZONTE A:}

volume 1 - $\mathbf{0 - 3} \mathbf{c m}$ : bruno (7,5YR 5/3); arenoso, rico em areia lavada; estrutura pequena granular; limite inferior abrupto e contraste médio; coesão fraca; transição abrupta e ondulada.

\section{HORIZONTE E:}

volume 2 - 3-50/60 cm: cor média bruno-avermelhado (5YR 5/3,5) finamente heterogêneo. Com a lupa observou-se volumes formando uma rede milimétrica de areia limpa interpenetrado com um fundo bruno-avermelhado claro um pouco maior. Presença de pequenos volumes vermelhos parecendo com preenchimentos observados na lupa e não manchas frequentemente tubulares; arenoso; estrutura maciça; porosidade intergranular e tubular forte; transição gradual e ondulada.

volume $3-19-30 \mathrm{~cm}$ : dois volumes de cor cinza com manchas cor ocre filamentosas (7,5YR 5,5/3 fundo e 5YR 4/6 manchas). O limite dessas bolsas é abrupto e a porosidade é forte; coesão média a fraca; transição abrupta. 


\section{HORIZONTE DE TRANSICCÃO E/Bt:}

volume 4 - 50/60-61cm: vermelho-amarelado (5YR 4/6) que vistos com a lupa constituem volumes formando uma rede descontínua de areia limpa numa malha de $5 \mathrm{~mm}$, são túbulos milimétricos numerosos, constituídos de areia rosada (7,5YR 7/4). Mais duro com a faca (seco); areno-argiloso; estrutura maciça com fratura conchoidal; porosidade tubular intergranular bem desenvolvida porém menos que o volume superior; coesão forte; transição clara e plana para a base, mas gradual lateralmente.

volume 5 - 50/60-68/80cm: heterogêneo, fundo bruno-avermelhado (5YR 5/4) com numerosos volumes milimétricos de areia limpa rosada (7,5YR 7/4). Presença de grandes domínios ( $5 \mathrm{~cm}$ ) apresentando volumes (rede) bruno-avermelhados (5YR 4,5/6) englobando domínios do fundo precedente e com volume de areia clara milimétrica e mais abundante; textura arenosa a areno-argilosa; estrutura maciça; porosidade tubular e intergranular forte; coesão fraca; transição abrupta e ondulada.

\section{HORIZONTE Bt:}

volume 6 - $61 \mathrm{~cm}+$ : nitidamente mais vermelho (2,5YR 4/6), homogêneo; textura argiloarenosa; estrutura maciça com fratura tendendo a poliédrica; porosidade tubular e intergranular medianamente desenvolvida; coesão muito forte. Para a base (a mais de $1 \mathrm{~m}$ de profundidade) existem domínios centimétricos bruno-avermelhados que correspondem a revestimentos argilosos bem nítidos quando observados com lupa nas fratura dos torrões; transição descontínua.

volume 7 - 68/80cm: heterogêneo. É constituído por um fundo bruno-avermelhado (2,5YR 4/6) muito parecido com o descrito anteriormente, tanto do ponto de vista da cor, como da organização do fundo matricial. Presença de numerosos domínios mais ou menos tubulares localmente anastomosados brunos (7,5YR 5,5/4). Os domínios brunos são mais arenosos, textura argilo-arenosa, estrutura moderada média poliédrica, porosidade intergranular e tubular bem desenvolvida, coesão média; transição descontínua.

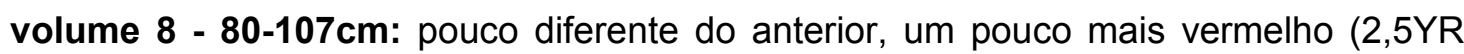
4/6). Tem os mesmos volumes tubulares e anastomosados mais arenosos e mais porosos; estrutura fraca média poliédrica; porosidade tubular a intergranular. Volumes 
brunos tem porosidade intergranular maior e mais desenvolvida. Apresenta também como o Bt revestimentos bruno-avermelhados sobre as faces estruturais e também na face jusante da trincheira poros bordejados de amarelo pouco abundantes e que vão aumentar na trincheira seguinte; coesão fraca (úmido); transição clara e plana.

Tradagem: no fundo da trincheira 5:

150-170 cm: seixos a $150 \mathrm{~cm}$ de profundidade e também nódulos ferruginosos violáceos. Cor vermelho (2,5YR 4,5/4), areno-argiloso a argilo-arenoso, volumes de areia lavada quase brancos.

\section{ALTERITA DO ARENITO:}

170-285cm+: aparecimento de volumes amarelo-claros pouco contrastados (10YR 7/4) e vermelhos (2,5YR 4,5/8); textura arenosa e areno-argilosa respectivamente. Para a base aparecem volumes brancos e violáceos (10R 4,5/6); textura arenosa.

\section{TRINCHEIRA 6:}

\section{HORIZONTE A:}

volume 1 - 0-4cm: bruno (7,5YR 4/2), bruno acinzentado (úmido); areia lavada abundante, arenoso, parcialmente contrastada ao redor dos poros; raízes abundantes; transição clara e plana.

\section{HORIZONTE E:}

Volume 2 - 4-63cm: bruno-forte $(7,5 Y R$ 4/6) cor geral heterogêneo, volumes milimétricos arredondados muito numerosos bruno-claros $(7,5 Y R$ 6,5/4) constituídos por areia limpa. Existem também manchas bruno-avermelhadas (5YR 5/8) ao redor dos poros, bastante numerosos; arenoso; estrutura maciça, porosidade tubular intergranular forte principalmente em volumes bruno-claros; coesão média a fraca; transição clara e plana. 


\section{HORIZONTE Bt:}

volume 3 - 63-112cm: mais duro com a faca (seco); cor heterogênea com fundo vermelho-escuro a vermelho-amarelado (2,5YR e $5 \mathrm{YR} 4 / 6)$ com domínios amarelos ao redor de alguns poros de cor bruno-amarelados (10YR 5,5/6); textura argilo-arenosa; estrutura forte média poliédrica; porosidade tubular medianamente desenvolvida; coesão muito forte. Os revestimentos nas faces estruturais são mais numerosos que na trincheira 5 e de cor 5YR 4/4; transição gradual e plana.

volume 4 - 77-102cm: volume que difere do anterior por uma cor geral muito mais amarela, muito heterogêneo com fundo bruno-amarelado (10YR 5/4). Domínios vermelhos centimétricos vermelho-escuros (2,5YR 4/7), pouco abundantes. Domínios difusos bruno-forte (7,5YR 4,5/6). Dentro da fase amarela-clara aparecem manchas ocre ao redor dos poros. O resto idem ao anterior.

\section{HORIZONTE C1C:}

volume 5 - 102-112cm+: vermelho-amarelado (5YR 5/8) mais vermelho com domínios amarelos ao redor dos poros; presença de revestimentos argilosos pouco abundantes; textura argilo-arenosa; estrutura fraca média poliédrica; porosidade tubular medianamente desenvolvida.

\section{TRINCHEIRA 1:}

\section{HORIZONTE A:}

volume 1 - 0-2/11cm: bruno (10YR 4/3); arenoso; com volumes esbranquiçados de areia lavada; estrutura fraca pequena poliédrica; porosidade intergranular forte (predominante) e tubular com raízes fasciculadas finas (comuns); fragmentos de seixos de quartzo (centimétrico); muito úmido (pela chuva do dia anterior); transição clara e ondulada.

volume 2 - 2/11-20cm: bruno (10YR 4/3); arenoso com presença de volumes de carvão milimétricos a centimétricos dispersos em pouca quantidade e fragmentos de lamito vermelho (10R 4/8), pouca areia lavada; início de manchas (rede) pouco contrastadas bruno-forte (7,5YR 5/8); estrutura fraca pequena poliédrica; porosidade intergranular forte e tubular muito fraca; transição clara e ondulada. 


\section{HORIZONTE E:}

volume 2a - 10-22cm: volume bruno-acinzentado muito escuro (10YR 3/2); arenoso; diferencia-se pela cor mais escura do que o anterior e quantidade de areia lavada (contrastante). As manchas (rede) continuam com contraste pouco nítido em relação ao fundo.

volume 3 - 20-32/50cm: bruno-amarelado-escuro a bruno (10YR 4/4 e 4/3); arenoso; menos úmido que o anterior. De montante a jusante há um aumento das manchas (rede) bruno-amareladas em contraste e intensidade, com cores mais definidas do topo para a base; estrutura fraca pequena poliédrica; porosidade intergranular forte; transição gradual e plana.

\section{HORIZONTE DE TRANSICÃO E/Btg:}

volume 4 - 32/50-50/57cm: bruno (10YR 4/3); arenoso a areno-argiloso; as manchas (rede) bruno-amareladas ficam mais contrastadas com cores mais definidas; estrutura moderada média poliédrica; porosidade intergranular forte e porosidade tubular pedológica e biológica aumentam sensivelmente. Há um gradiente de diminuição de montante a jusante do contraste e intensidade da rede bruno-amarelada, fica mais acinzentado a jusante, mais úmido que o $\mathrm{E}$; transição gradual e plana.

volume 5 -50/57-80cm: bruno-forte (7,5YR 4/6); argilo-arenoso a argiloso com seixos esparsos próximos a base; estrutura moderada grande poliédrica; porosidade tubular forte e porosidade fissural só aparece com a penetração da faca; transição abrupta e ondulada.

volume 6 - 80-85cm: seixos de $10 \mathrm{~cm}$ (tipo fluvial) compostos de quartzos, com tendência a orientação (moderadamente orientados paralelamente à vertente assemelhando-se a stone-line). Seixos menores de 1 a $2 \mathrm{~cm}$ de quartzo e manganês, arredondados, laminares e subangulares (subarredondados); transição abrupta e plana.

\section{HORIZONTE Btg:}

volume 7 - 85-110cm: horizonte mosqueado, apresentando-se mais vermelho à montante (mais vermelho que o $\mathrm{Bt}$ e a jusante torna-se mais acinzentado) vermelhoescuro (2,5YR 4/8) e a jusante é vermelho-amarelado (5YR 5/8); argiloso; estrutura 
fraca grande poliédrica; porosidade tubular grande; umidade idem ao anterior; transição abrupta e irregular.

\section{VOLUME DE TRANSIÇÃO Btg/ALTERITA DO ARENITO:}

volume 7a - 90-140cm: volume bruno-amarelado (10YR 5/4); argilo-siltoso; bolsões que se diferenciam pela cor, textura e estrutura; estrutura maciça; transição gradual e irregular com interpenetração.

\section{ALTERITA DO ARENITO:}

volume 8 - 110-170 cm+: amarelo (10YR 7/6); textura argilo-siltosa; estrutura maciça; porosidade intergranular. As litorrelíqueas vermelhas (blocos) aumentam de tamanho e frequência.

\section{TRINCHEIRA 2:}

Nesta serão destacadas as diferenças ou modificações em relação à trincheira anterior.

\section{HORIZONTE A:}

volume 1 - 0-8cm: bruno (7,5YR 4/2); com areia lavada; muitas raízes; estrutura grande granular; porosidade intergranular; transição abrupta e ondulada.

\section{HORIZONTE E:}

volume 2 - 8-27cm: bruno (7,5YR 4/2); ligeiramente úmido, volumes de areia lavada dispersos; rede muito difusa bruno-amarelada; estrutura maciça; porosidade tubular rara; transição clara e ondulada.

volume 2a - 12-26cm: volume bruno-acinzentado-escuro (10YR 4/3); volumes formando bolsões alongados dentro do anterior que se diferencia deste pela maior intensidade da rede bruno-amarelada.

Volume 3 - 27-48cm: cor idem aos bolsões, com maior contraste da rede brunoamarelada; arenoso; porosidade intergranular; estrutura maciça; porosidade tubular fraca, ligada à presença de raízes; transição clara e ondulada. 


\section{HORIZONTE DE TRANSIČ̃̃O E/Btg:}

volume 4 - 48-55/75cm: bruno (10YR 5/3) e rede bruno-forte (7,5YR 5/6 e 5/8). A cor está associada à presença de raízes; estrutura fraca grande poliédrica; porosidade tubular forte; transição clara e irregular.

\section{HORIZONTE Btg:}

volume 5 - 55/75-80cm: mosqueado bruno-forte (7,5YR 5/6), constituindo volumes centimétricos envolvidos por manchas (rede) de cor cinzenta-brunada-clara (10YR 6/2); textura argilosa, muito pegajosa; estrutura poliédrica. Este horizonte é penetrado por línguas verticais 10YR; porosidade tubular forte; transição abrupta e plana.

\section{HORIZONTE DE TRANSIÇÃO Btg/ALTERITA DO ARENITO:}

volume 6 - 80-82cm: matriz da stone-line; bruno-amarelado (10YR 5/8) e brunoamarelado-escuro (10YR 4/6); transição clara e plana.

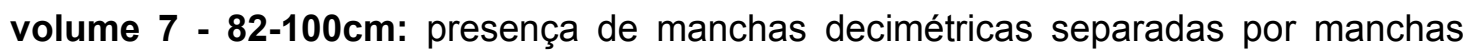
cinza em 10YR 5/2; idem.

\section{ALTERITA DO ARENITO:}

volume 8 - 100-122/132cm: distingue-se do anterior por apresentar relíquias centimétricas angulares e subangulares do arenito; vermelho (10R 4/6 e 4/8); arenoso, com fragmentos do arenito arenoso a areno-siltoso; os limites da fase avermelhada para a cinza são difusos; estrutura maciça; porosidade tubular forte; transição clara e ondulada.

volume 9 -122/132-140cm: amarelo-brunado (10YR 6/6), se distinguindo do anterior por apresentar uma cor mais pálida no conjunto; transição clara e plana.

volume $10-130-140 \mathrm{~cm}+$ : amarelo (10YR 7/6); argilo-siltoso a argiloso, menos úmido que os anteriores; estrutura maciça; porosidade intergranular. 


\section{TRINCHEIRA 7:}

\section{HORIZONTE A:}

volume 1 - 0-5cm: bruno-acinzentado muito escuro (10YR 3/2), muito arenoso, rico em areia lavada; raízes muito abundantes diminuem proporcionalmente até o arenito; estrutura fraca pequena poliédrica; porosidade intergranular forte; transição clara e plana.

\section{HORIZONTE Eg:}

volume 2 - 5-11cm: bruno-acinzentado-escuro (10YR 4/2), muito arenoso, rico em areia lavada dentro dos poros; estrutura maciça; porosidade intergranular forte; coesão fraca (úmido); transição clara e plana.

volume 3 - 11-57cm: bruno (10YR 4,5/3); arenoso, com volumes milimétricos de areia branca abundante; estrutura maciça; porosidade intergranular forte; coesão fraca; transição abrupta e plana.

\section{HORIZONTE DE TRANSIÇÃO Eg/ALTERITA DO ARENITO:}

volume 4 - 57-74cm: bruno (10YR 5/3) com numerosas manchas ocres ao redor dos poros vermelho-amarelados (5YR 5/8); textura areno-argilosa, mais duro que o $\mathrm{E}$; estrutura moderada média poliédrica; porosidade tubular e intergranular média desenvolvida; coesão média (úmido); transição clara e plana.

\section{ALTERITA DO ARENITO:}

volume 5 - 74-98cm: bruno claro 10YR 6/3, manchas ocre ao redor dos poros, volumes centimétricos vermelho-escuros de arenito alterado duros com auréola bruno-escura (volumes $=10 \mathrm{R} 3 / 8$ e auréola $=7,5 \mathrm{YR} 5 / 6$ ).

volume 6 - 98-140cm: fundo cinzento-claro (10YR 7/2) com volumes de arenito alterado vermelho ramificados com auréola bruno-forte no topo e branco na base (10R $3,5 / 8$ e auréola $=7,5 \mathrm{YR} 5 / 8$ ); textura do cinza é arenosa a areno-argilosa; textura do arenito é arenosa; porosidade do cinza é tubular e intergranular forte; porosidade do arenito é fina e fraca; transição gradual e ondulada. 
volume $7-140 \mathrm{~cm}+$ : idem anterior, mas a estratificação é sublinhada por estrias vermelhas separadas por material ocre.

\section{TRINCHEIRA 8:}

Obs: Esta trincheira não foi representada em desenho por ser semelhante à TR 7.

\section{HORIZONTE A:}

0-5cm: bruno-acinzentado muito escuro $(10 Y R 3 / 2,5)$ com muita areia lavada, muito arenoso; estrutura fraca pequena poliédrica; raízes muito abundantes (abundantes até $20 \mathrm{~cm}$ diminuindo depois e permanece até $120 \mathrm{~cm}$ ); porosidade intergranular forte; transição clara e plana.

\section{HORIZONTE Eg:}

5-11cm: mais claro, bruno $(7,5 Y R \quad 4 / 3)$, areia lavada abundante; manchas brunoavermelhados ao redor dos poros, arenoso; estrutura maciça; porosidade intergranular e tubular forte; coesão fraca; transição clara e plana.

11-60cm: bruno (7,5YR 5,5/2); extremamente rico em volumes milimétricos arredondados ou tubulares cinza-claro, constituídos por areia limpa, certos poros são bordejados por ocre, arenoso; estrutura maciça; porosidade intergranular forte e alguns poros tubulares; coesão média; transição abrupta e plana.

\section{HORIZONTE DE TRANSIÇÃO Eg/ALTERITA DO ARENITO:}

60-75cm: bruno (7,5YR 5/3); arenoso a areno-argiloso, manchas ocres pouco contrastadas ao redor dos poros; estrutura fraca média poliédrica; porosidade tubular e intergranular medianamente desenvolvida; coesão média; transição clara e ondulada.

\section{ALTERITA DO ARENITO:}

75-90cm: heterogêneo, fundo bruno-claro-acinzentado (10YR 6,5/3) com poros bordejados de ocre, volumes de arenito alterado centimétricos de forma muito irregular vermelho-amarelado (5YR 5/8) e periferia bruno-amarelada (7,5YR 5/8); textura areno- 
argilosa; porosidade do fundo é tubular e intergranular dentro de volumes com areia lavada. O arenito tem uma porosidade fina não visível; transição gradual e ondulada.

90-140cm+: fundo cinzento-claro $(7,5 Y R$ 7,5/2) com grandes volumes vermelhoescuros $(10 R 3,5 / 8)$ com auréola ocre no topo e sem auréola para a base. As duas fases são arenosas; a porosidade no fundo é intergranular e tubular bem desenvolvida e a porosidade do arenito vermelho alterado não é visível com a lupa.

\section{TRINCHEIRA 4:}

\section{HORIZONTE A:}

volume 1 - 0-10cm: bruno-acinzentado (10YR 5/2) ao fundo e manchas vermelhoamareladas (5YR 5/6) ao redor dos poros pouco contrastadas; textura arenosa; estrutura fraca média poliédrica achatada horizontal com tendência a laminar; porosidade intergranular fina medianamente desenvolvida e tubular fraca; raízes abundantes agrupadas na base dos tufos de capim; coesão média a fraca; transição clara e plana.

\section{HORIZONTE Eg:}

volume $2-10-5 / 35 \mathrm{~cm}$ : ligeiramente mais claro, as manchas aumentam e são mais contrastantes associadas aos poros, areia branca muito abundante freqüentemente desenhando manchas (redes milimétricas ou pequenas bolsas de até $5 \mathrm{~mm}$ ) devido a areia branca associada aos poros; textura arenosa; estrutura fraca grande poliédrica; as raízes são menos abundantes e também localizadas abaixo dos tufos; coesão média a fraca; transição abrupta e plana.

volume 3 - 15/35-55cm: cor de fundo bruno (10YR 5/3) e manchas abundantes localizadas nas paredes dos poros vermelho-amareladas (5YR 4/8); textura arenoargilosa; estrutura maciça com fratura regular plana e um pouco conchoidal; porosidade tubular média a fraca e algumas fendas verticais; coesão muito forte; transição clara e plana. 


\section{HORIZONTE DE TRANSIÇÃO Eg/ALTERITA COM JUSTAPOSIÇÃO:}

volume 4 - 40-55cm: volume constituído por areia branca com manchas bruno amarelo-claros associadas aos poros. Cor das manchas é bruno-forte $(7,5 \mathrm{YR} 5 / 8)$ e do fundo bruno muito claro-acinzentado (10YR 7/3); porosidade interticial e tubular forte; transição clara e plana.

\section{ALTERITA COM JUSTAPOSIÇÃO:}

volume 5 - 55-65cm: o fundo é mais claro $10 \mathrm{YR}$ 6/3, numerosas manchas filamentosas de cor vermelho-amarelada (5YR 5/8) e também manchas difusas amarelo-avermelhadas (7,5YR 6/6).

Esse horizonte corresponde ao aparecimento de volumes amarelo-avermelhados (5YR 6/8) e amarelos (10YR 8/8) bordejando os poros; textura areno-argilosa; estrutura poliédrica irregular ou maciça com fratura conchoidal; porosidade tubular fraca; coesão forte; transição clara e ondulada.

volume 6 - 65-90cm: constituído por uma justaposição de volumes entre 5 e $15 \mathrm{~cm}$ de cor violácea e ocre bordejadas de uma banda branca de menos de $5 \mathrm{~mm}$ de espessura. A forma deles é grosseira e retangular com eixo menor vertical. Esses blocos são separados por um material de cor cinzento-brunado-claro (10YR 6/2). A cor dos volumes é vermelho (10R 4/8) e amarelo-avermelhado (7,5YR 6/8).

O violáceo está localizado no centro dos volumes e o ocre na periferia. O material bruno-acinzentado desenha uma rede mais ou menos retangular. A espessura das bandas bruno acinzentadas vai de $1 \mathrm{~mm}$ até $2 \mathrm{~cm}$.

Textura dos blocos = arenosa fina.

Textura das manchas (rede) bruno-acinzentadas = arenosa a areno-argilosa.

A porosidade dos blocos não é visível. A porosidade da rede é tubular bem desenvolvida. As raízes exploram a rede bruno acinzentada. Os blocos são relíquias do material de alteração subjacente (arenito); transição clara e plana.

\section{ALTERITA DO ARENITO:}

volume 7 - 90cm+: cor dominante vermelho-acinzentado (10R 5,5/4). Existem domínios brancos em bandas horizontais de 2 até $10 \mathrm{~cm}$ de espessura. Os domínios de $10 \mathrm{~cm}$ estão localizados no topo. Existem também bandas verticais de $2 \mathrm{~cm}$ de espessura bordejando fendas; textura arenosa fina; estrutura maciça; a porosidade 
não é visível. Localmente tem canais de raízes em forma de baioneta horizontal e vertical bordejadas de branco.

\section{TRINCHEIRA 9:}

Obs: esta trincheira não foi representada em desenho por ser semelhante à TR 4.

\section{HORIZONTE A:}

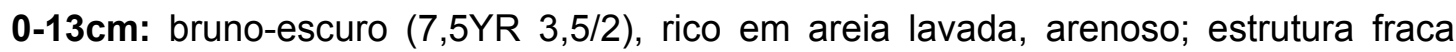
média poliédrica; porosidade intergranular e interagregados forte; transição gradual e plana.

\section{HORIZONTE Eg:}

13-30 cm: bruno (7,5YR 4,5/2); arenoso; estrutura fraca média poliédrica; porosidade intergranular e tubular bem desenvolvida; raízes abundantes que diminuem para a base do perfil, mas permanecem abundantes na fase cinza do último horizonte; coesão fraca; transição gradual e plana.

\section{HORIZONTE DE TRANSIÇÃO Eg/ALTERITA COM JUSTAPOSIÇÃO:}

30-55cm: bruno (7,5YR 4/3,5); arenoso com um pouco de argila; úmido; estrutura fraca média poliédrica; porosidade intergranular e tubular bem desenvolvida; coesão fraca. Presença de alguns nódulos ferruginosos dispersos até $4 \mathrm{~cm}$, fortemente mamelonares, muito duros, seção de cor violácea, muito homogênea, grãos de quartzo do arenito cimentados por óxido de ferro; transição gradual e ondulada.

\section{ALTERITA COM JUSTAPOSIÇÃO:}

55-70 cm: ligeiramente mais vivo, bruno-forte $(7,5 \mathrm{YR} 5 / 5)$, manchas brunoavermelhadas pouco contrastadas ao redor de certos poros; textura arenosa a arenoargilosa; estrutura fraca média poliédrica; porosidade tubular e intergranular bem desenvolvida, presença de volumes ocres de arenito alterado aumentando para base (centimétricos e um pouco mais coerentes) ; coesão fraca; transição clara e ondulada. 70-110cm+: blocos de arenito bruno-amarelado claro no topo. Passando de $80 \mathrm{~cm}$ há vermelho-violáceo-claro. Estes blocos apresentam uma periferia centimétrica branca. 
Eles são separados por um material quase branco pouco abundante cinzento-claro (10YR 7/2), arenoso, fortemente explorado pelas raízes. A espessura deste material entre os blocos é da ordem de $1 \mathrm{~cm}$. A porosidade deste material é intergranular forte. A cor do arenito do topo é bruno-forte $(7,5 Y R 5 / 8)$ e a cor do violáceo claro é constituído por pontuações vermelho-acinzentadas (10R 5/4) num fundo branco. 


\section{ANEXO III}

TABELA 1 - Distribuição percentual de plasma, esqueleto e poros por horizonte na Topossequência Retiro I

\begin{tabular}{|c|c|c|c|c|c|c|c|c|c|c|}
\hline $\begin{array}{l}\text { Perfis } \\
\text { Horizontes }\end{array}$ & SPFR 14 & SPFR 8 & TR 10 & TR 3 & TR 5 & TR 6 & TR 1 & TR 2 & TR 7 & TR 4 \\
\hline$\%$ & $\begin{array}{|lll|}\mathbf{P} & \mathbf{E} & \mathbf{P o}\end{array}$ & $\begin{array}{|lll|}\mathbf{P} & \mathbf{E} & \mathbf{P o}\end{array}$ & $\begin{array}{|lll|}\mathbf{P} & \mathbf{E} & \mathbf{P o}\end{array}$ & \begin{tabular}{|lll} 
P & E & Pó
\end{tabular} & $\begin{array}{|lll|}\mathbf{P} & \mathbf{E} & \mathbf{P o}\end{array}$ & $\begin{array}{|lll|}\text { P } & \text { E } & \text { Po }\end{array}$ & $\begin{array}{|lll|}\mathbf{P} & \mathbf{E} & \mathbf{P o}\end{array}$ & $\begin{array}{|lll|}\text { P } & \text { E } & \text { Po }\end{array}$ & $\begin{array}{|lll|}\text { P } & \text { E } & \text { Po }\end{array}$ & $\begin{array}{|lll|}\mathbf{P} & \mathbf{E} & \mathbf{P o} \\
\end{array}$ \\
\hline $\bar{A}$ & $\begin{array}{|lll|}5 & 55 & 40\end{array}$ & --------- & -------- & --------- & -------- & -------- & -------- & -------- & -------- & \begin{tabular}{|lll}
5 & 50 & 45
\end{tabular} \\
\hline $\mathrm{E}$ & $\begin{array}{|lll|}10 & 50 & 40\end{array}$ & $\begin{array}{|lll|}5 & 55 & 45\end{array}$ & $\begin{array}{|lll|}5 & 60 & 35 \\
\end{array}$ & $\begin{array}{|lll|}5 & 55 & 40\end{array}$ & $\begin{array}{|lll|}10 & 60 & 30 \\
\end{array}$ & -------- & $\begin{array}{|lll|}15 & 55 & 30\end{array}$ & --------- & $\begin{array}{|lll|}5 & 60 & 35\end{array}$ & \begin{tabular}{|lll}
5 & 55 & 45
\end{tabular} \\
\hline E (bandas) & $\begin{array}{|lll|}35 & 45 & 20\end{array}$ & $\begin{array}{|lll|}40 & 50 & 10\end{array}$ & --------- & -------- & -------- & --------- & -------- & -------- & -------- & -------- \\
\hline $\mathrm{Bt}$ & --------- & --------- & --------- & $\begin{array}{|lll|}30 & 45 & 25\end{array}$ & $\begin{array}{|lll|}35 & 50 & 15\end{array}$ & $\begin{array}{|lll|}30 & 55 & 15\end{array}$ & $\begin{array}{|lll|}40 & 45 & 15\end{array}$ & $\begin{array}{|lll|}30 & 45 & 25\end{array}$ & -------- & --------- \\
\hline $\mathrm{C} 1 \mathrm{a}$ & $\begin{array}{|lll|}15 & 50 & 35 \\
\end{array}$ & -------- & -------- & $\begin{array}{|lll|}20 & 50 & 30 \\
\end{array}$ & -------- & ------- & -------- & -------- & -------- & -------- \\
\hline $\begin{array}{l}\text { Alterita do } \\
\text { arenito }\end{array}$ & - & - ------- & --------- & ------ & --------- & --------- & $\begin{array}{|lll|}30 & 50 & 20\end{array}$ & $\begin{array}{lll}30 & 40 & 30\end{array}$ & $\begin{array}{|lll|}25 & 60 & 15\end{array}$ & --------- \\
\hline $\begin{array}{l}\text { Alter. com } \\
\text { just. (rede } \\
\text { bruna) }\end{array}$ & --------- & --------- & --------- & (-------- & - -------- & --------- & - -------- & --------- & --------- & $\begin{array}{lll}20 & 45 & 35\end{array}$ \\
\hline $\begin{array}{l}\text { Alter. com } \\
\text { just. } \\
\text { (arenito) }\end{array}$ & --------- & --------- & --------- & --------- & --------- & --------- & --------- & --------- & --------- & $\begin{array}{|lll|}25 & 60 & 15\end{array}$ \\
\hline
\end{tabular}

$\begin{array}{lll}P=\text { plasma } & E=\text { esqueleto } & P o=\text { poro }\end{array}$ 
TABELA 2 - Distribuição das estruturas de base por horizonte na Topossequência Retiro I

\begin{tabular}{|c|c|c|c|c|c|c|c|c|c|c|}
\hline $\begin{array}{l}\text { Perfis } \\
\text { Horizontes }\end{array}$ & SPFR 14 & SPFR 8 & TR 10 & TR 3 & TR 5 & TR 6 & TR 1 & TR 2 & TR 7 & TR 4 \\
\hline $\mathrm{A}$ & $\begin{array}{l}\text { mônica (d) } \\
\text { enáulica (s) }\end{array}$ & ------ & $\begin{array}{l}----- \\
\end{array}$ & $\begin{array}{l}----- \\
\end{array}$ & ------ & ------ & ------ & ----- & $\begin{array}{l}----- \\
\end{array}$ & enáulica (d) \\
\hline$E$ & \begin{tabular}{|l|} 
gefúrica $(\mathrm{d})$ \\
porfírica $(\mathrm{r})$ \\
\end{tabular} & mônica (d) & enáulica (d) & Gefúrica (d) & gefúrica (d) & ----- & gefúrica & ----- & gefúrica $(\mathrm{d})$ & enáulica (d) \\
\hline E (bandas) & \begin{tabular}{|l|} 
porfírica $(\mathrm{d})$ \\
gefúrica $(\mathrm{s})$
\end{tabular} & \begin{tabular}{|l} 
porfírica $(\mathrm{d})$ \\
gefúrica $(\mathrm{s})$
\end{tabular} & $\begin{array}{l}----- \\
\end{array}$ & ------ & $\begin{array}{l}----- \\
\end{array}$ & ------ & ------ & ------ & $\begin{array}{l}----- \\
\end{array}$ & ------ \\
\hline $\mathrm{Bt}$ & ------ & ------ & ------ & $\begin{array}{l}\text { Gefúrica }(\mathrm{d}) \\
\text { porfírica }(\mathrm{s})\end{array}$ & porfírica & porfírica & porfírica & $\begin{array}{l}\text { gefúrica }(\mathrm{d}) \\
\text { quitônica }(\mathrm{s})\end{array}$ & $\begin{array}{l}----- \\
\end{array}$ & $\begin{array}{l}----- \\
\end{array}$ \\
\hline Cla & \begin{tabular}{|l} 
gefúrica (d) \\
porfírica (r) \\
\end{tabular} & ----- & ------ & $\begin{array}{l}\text { gefúrica (d) } \\
\text { porfírica (r) }\end{array}$ & ----- & ----- & ------ & ------ & ------ & ------ \\
\hline \begin{tabular}{|l} 
Alterita do \\
arenito \\
\end{tabular} & ------ & ------ & ------ & ------ & ------ & ----- & gefúrica & $\begin{array}{l}\text { gefúrica }(\mathrm{d}) \\
\text { porfírica }(\mathrm{s})\end{array}$ & porfírica & ------ \\
\hline $\begin{array}{l}\text { Alterita com } \\
\text { justaposição }\end{array}$ & ------ & ------ & ------ & ------ & ------ & ------ & ------ & ------ & ------ & porfírica \\
\hline
\end{tabular}

$\mathrm{d}=$ dominante $\quad \mathrm{s}=$ secundária $\quad \mathrm{r}=$ rara


TABELA 3 - Distribuição das estruturas plásmicas por horizonte na Topossequência Retiro I

\begin{tabular}{|c|c|c|c|c|c|c|c|c|c|c|}
\hline $\begin{array}{l}\text { Perfis } \\
\text { Horizontes }\end{array}$ & SPFR 14 & \begin{tabular}{|l|} 
SPFR 8 \\
\end{tabular} & TR 10 & TR 3 & TR 5 & TR 6 & TR 1 & TR 2 & TR 7 & TR 4 \\
\hline $\mathrm{A}$ & opaco & & & & & & & & & isótico \\
\hline $\bar{E}$ & opaco & opaco & silassépica & $\begin{array}{l}\text { opaco }(\mathrm{d}) \\
\text { silassépica(s) }\end{array}$ & $\begin{array}{l}\text { silassépica }(\mathrm{d}) \\
\text { vossépica }(\mathrm{r}) \\
\end{array}$ & ----- & $\begin{array}{l}\text { opaco }(\mathrm{d}) \\
\text { silassépica }(\mathrm{r})\end{array}$ & ----- & silassépica & silassépica \\
\hline E (bandas) & \begin{tabular}{|l|} 
E-mossépica \\
Bandas- \\
esquelsépica e \\
vossépica \\
\end{tabular} & esquelsépica & ------ & ------ & ------ & $\begin{array}{l}----- \\
\end{array}$ & ------ & ------ & $\begin{array}{l}----- \\
\end{array}$ & ------ \\
\hline $\mathrm{Bt}$ & ------ & ------ & ------ & $\begin{array}{l}\text { opaco(d) } \\
\text { vossépica(s) }\end{array}$ & $\begin{array}{l}\text { mossépica(d) } \\
\text { esquelsépica } \\
\text { vossépica }(\mathrm{r}) \\
\end{array}$ & $\begin{array}{l}\text { mossépica(d) } \\
\text { vossépica (s) }\end{array}$ & $\begin{array}{l}\text { mossépica(d) } \\
\text { esquelsépica } \\
\text { vossépica }(\mathrm{s})\end{array}$ & $\begin{array}{l}\text { mossépica(d) } \\
\text { esquelsépica } \\
\text { vossépica }(r)\end{array}$ & ------ & ------ \\
\hline $\mathrm{C} 1 \mathrm{a}$ & opaco & ------ & $\begin{array}{ll}----- \\
\end{array}$ & opaco & ------ & $\begin{array}{ll}----- \\
\end{array}$ & ------ & ------ & $\begin{array}{ll}----- \\
\end{array}$ & $\begin{array}{ll}----- \\
\end{array}$ \\
\hline $\begin{array}{l}\text { Alterita do } \\
\text { arenito }\end{array}$ & ----- & ------ & ------ & ----- & ------ & ------ & $\begin{array}{l}\text { opaco }(\mathrm{d}) \mathrm{e} \\
\text { mossépica }(\mathrm{s})\end{array}$ & \begin{tabular}{|l} 
opaco (d) e \\
mossépica (s)
\end{tabular} & $\begin{array}{l}\text { opaco (d) } \\
\text { silassépica (s) }\end{array}$ & ------ \\
\hline $\begin{array}{l}\text { Alterita com } \\
\text { just. (rede } \\
\text { bruna) }\end{array}$ & ------ & ------ & ----- & ------ & ------ & ------ & ------ & ------ & ------ & silassépica \\
\hline $\begin{array}{l}\text { Alterita com } \\
\text { just. (arenito) }\end{array}$ & ------ & ------ & ----- & ------ & ------ & ------ & ------ & ------ & ------ & $\begin{array}{l}\text { argilassé- } \\
\text { pica e } \\
\text { opaco }(\mathrm{d})\end{array}$ \\
\hline
\end{tabular}

$\mathrm{d}=$ dominante $\quad \mathrm{s}=$ secundária $\quad \mathrm{r}=$ rara 
ANEXO IV

PRANCHA 4 - Variação textural em profundidade por perfil com valores percentuais acumulados
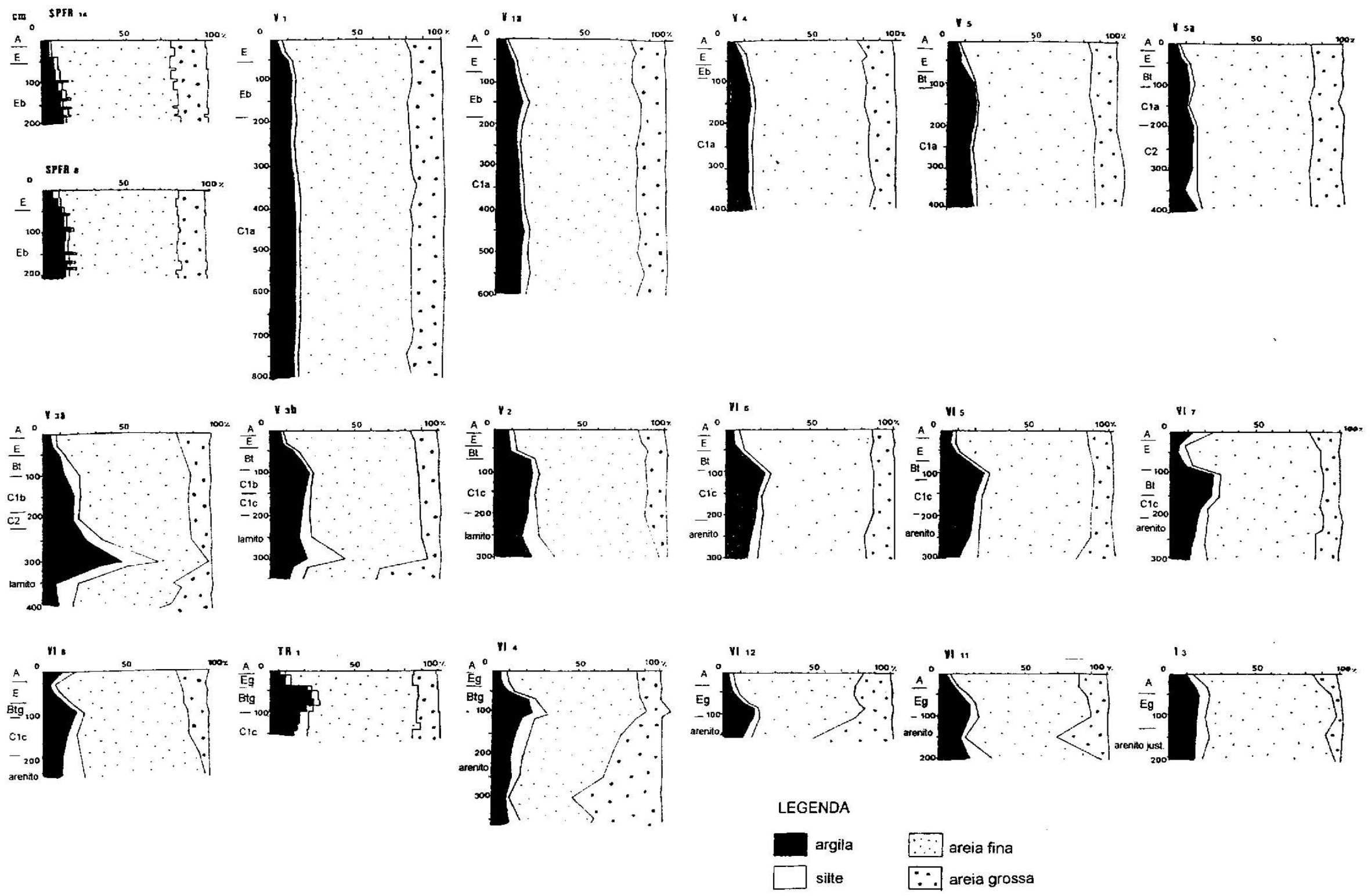
PRANCHA 5 - Variação em profundidade por perfil dos resultados das análises quimicas
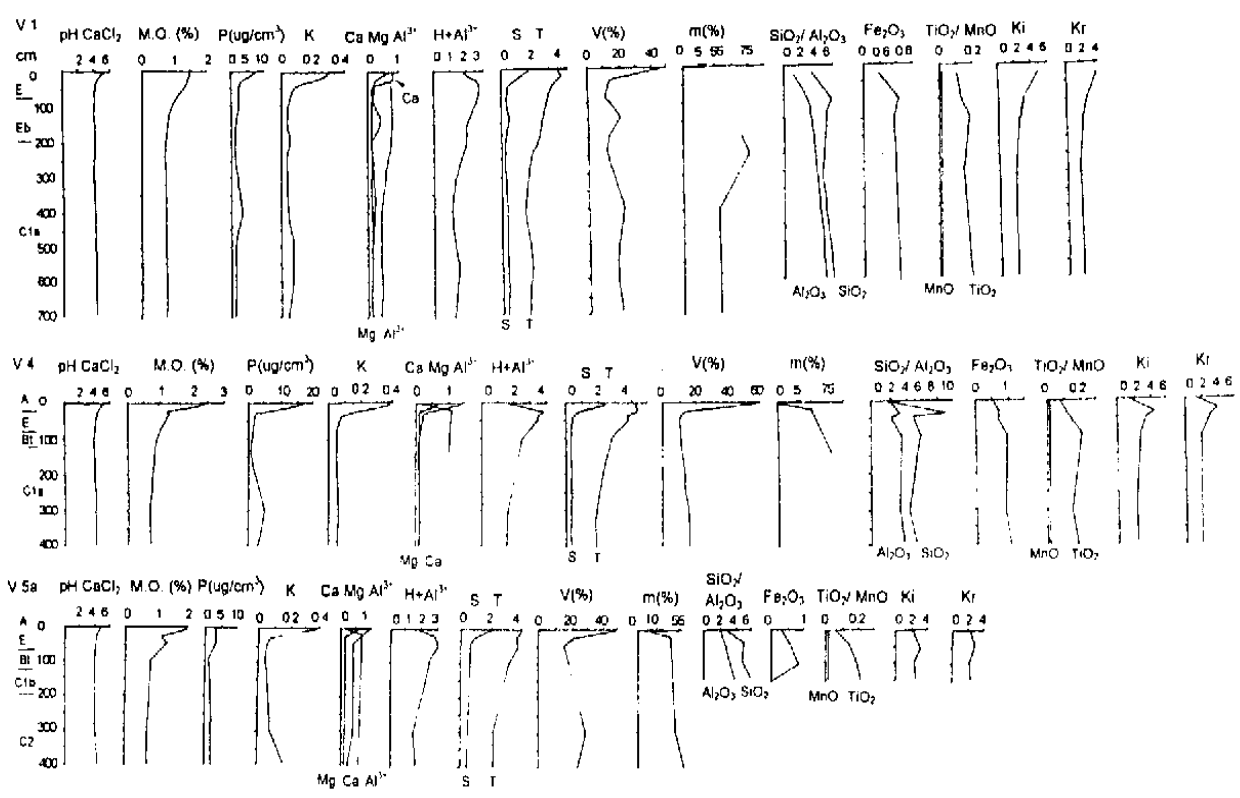

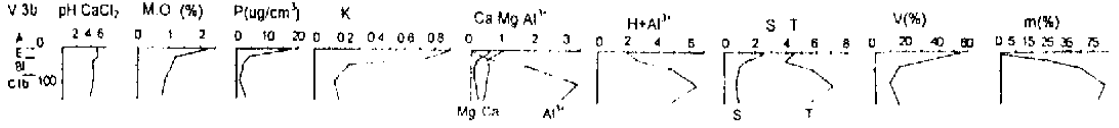

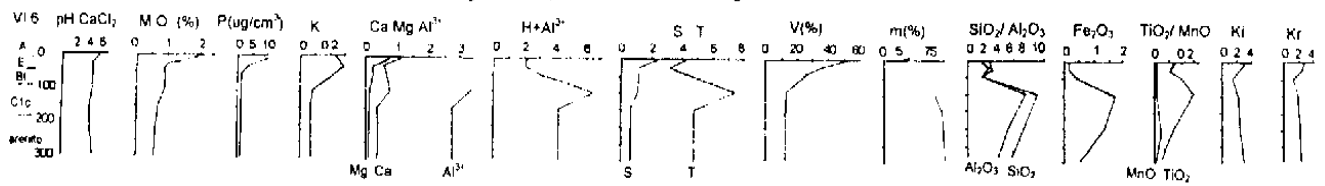

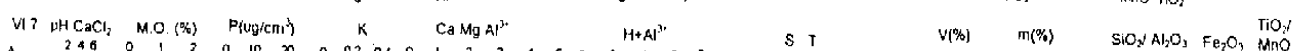

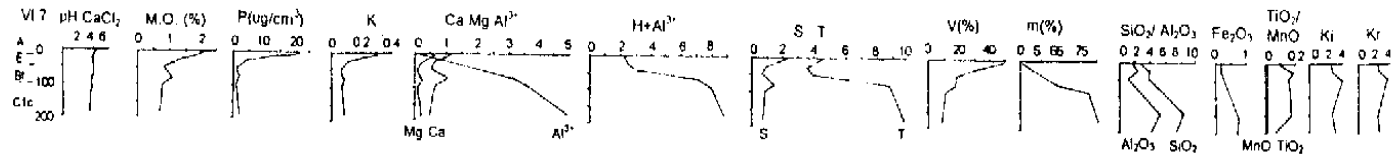

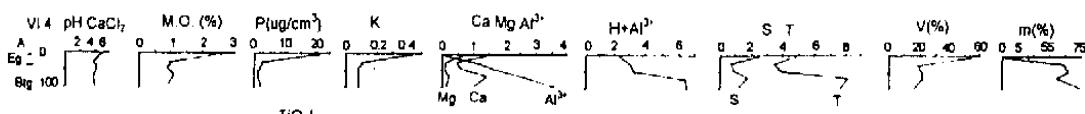

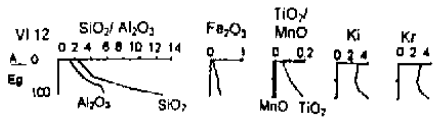

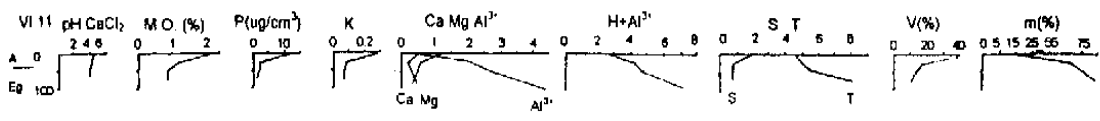

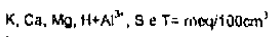

$\mathrm{SiO}_{3} . \mathrm{Al}_{2} \mathrm{O}_{3}, \mathrm{FB}_{3} \mathrm{O}_{3}, \mathrm{TO}_{3}, \mathrm{MnO}=\%$ 